

\section{HARVARD UNIVERSITY.}

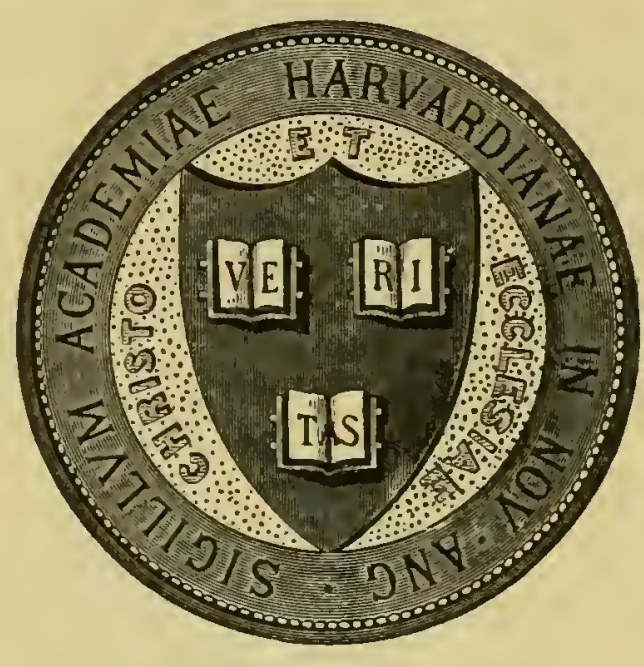

\section{I B R A R Y}

OF THE

MUSEUM OF COMPARATIVE ZOÖLOGY 7874 S

GIFT OF

$$
\text { Johu C. Phillibs }
$$

December 29,1936. 
DEC 291936 


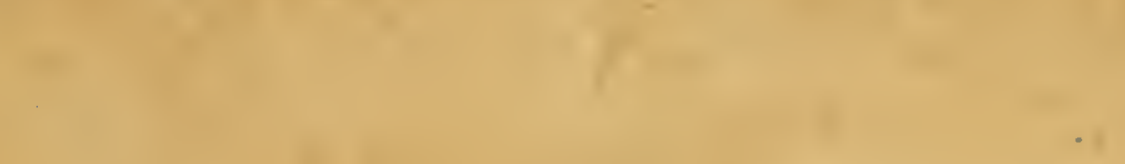

0
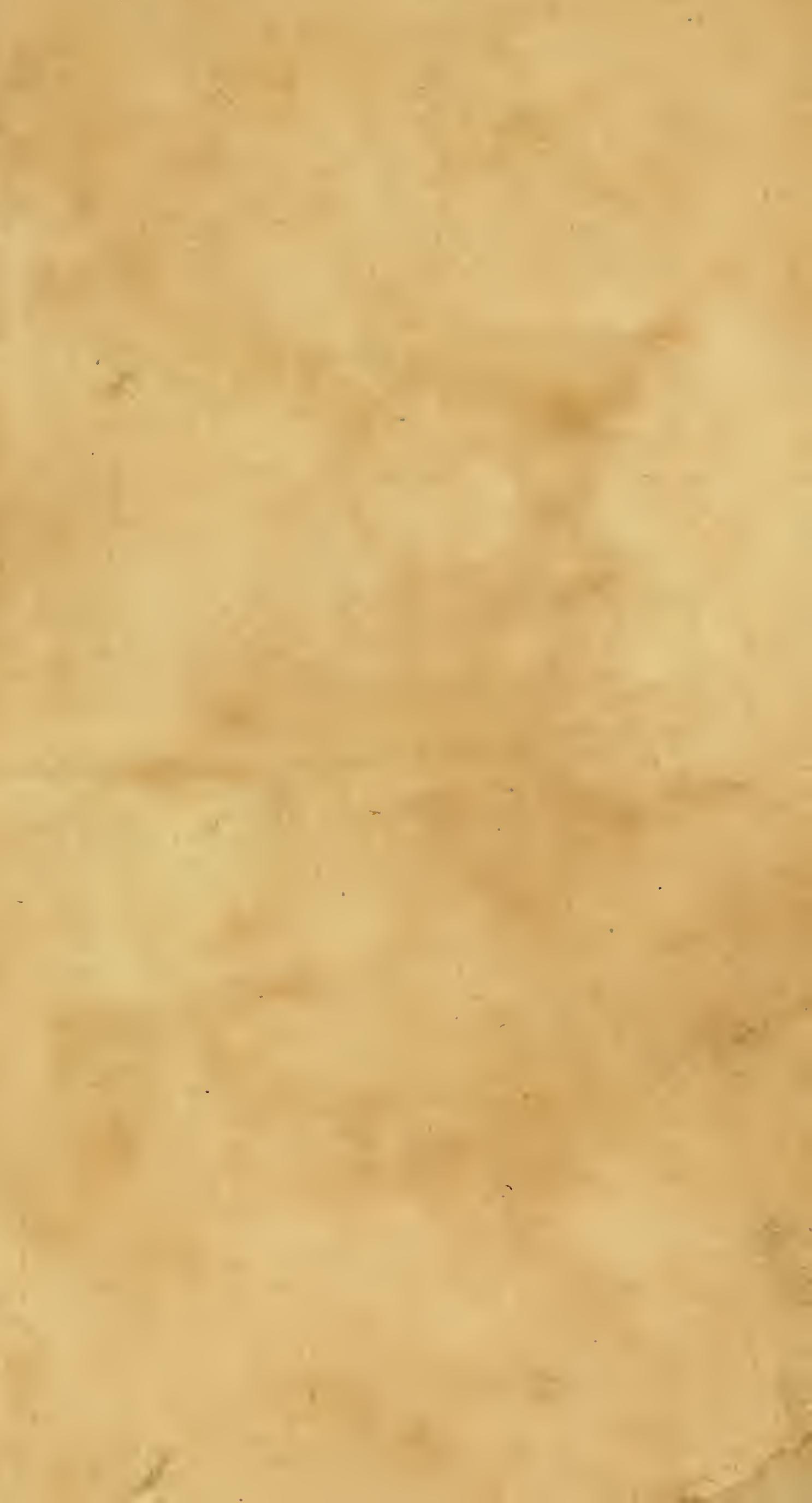


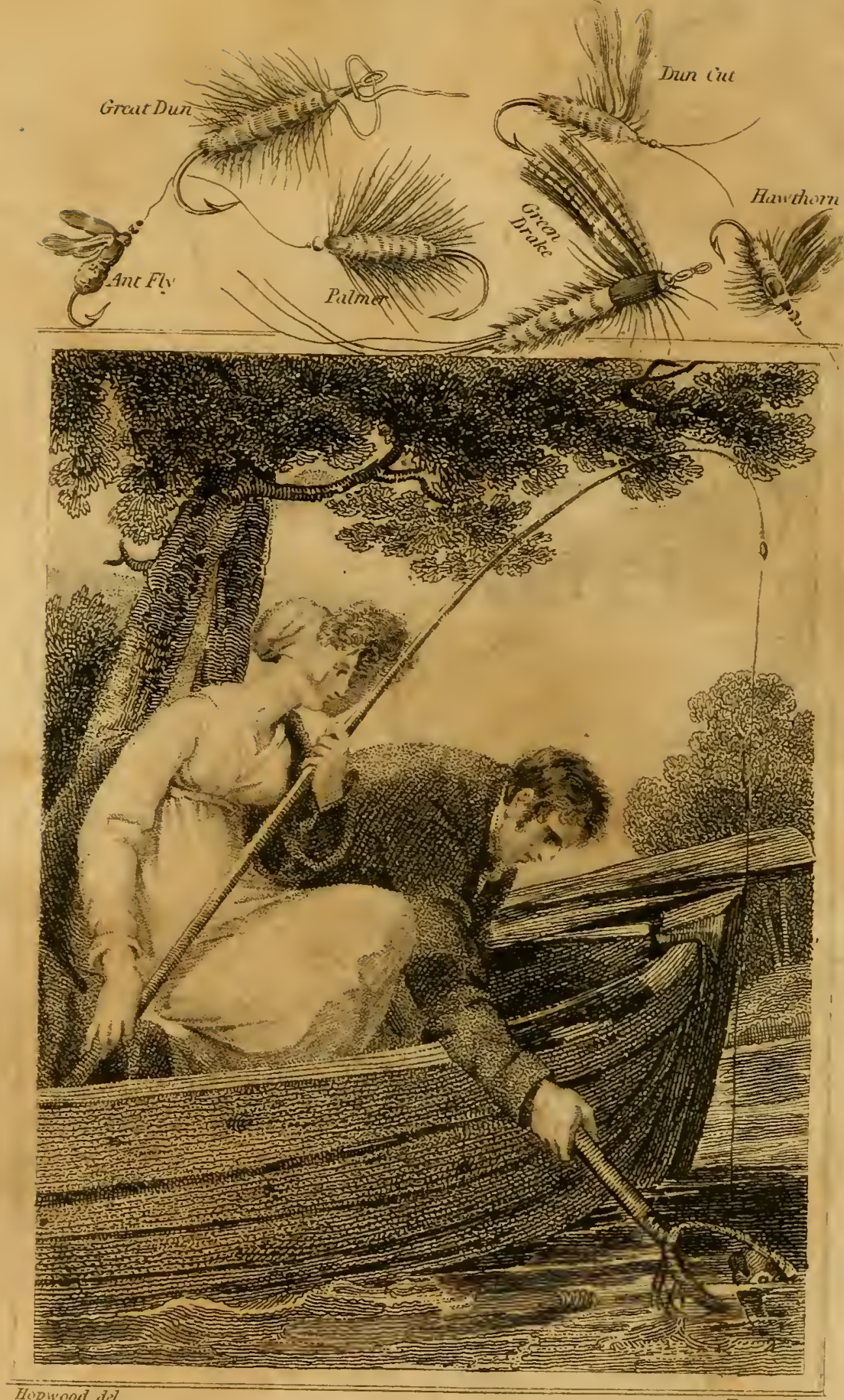

Elopunood al? Bopwed

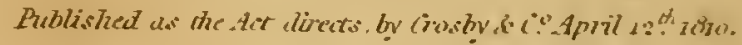




\title{
THE NINTH EDITION.
}

$\Lambda$

\section{CONCISE TREATISE}

\author{
ON THEl llilililil'
}

ART OF ANGLING,

Confirmed by actual Experience;

INTERSPERSED WITII

SEVERAL NEW AND RECENT DISCOVERIES;

FORMING

A COMPIETE MUSEUM,

FOR THE

IOVERS OF THAT FLEASING AND RATIONAL

RECREATION.

TO WHICII ARE ADDED

\section{PROGNOSTICS OF THE WEATHER}

INDEPENDENT OF THE BAROMETFE;

And

A NEW CHAPTER,

Containing Rules, how best to form a competent Judgement of the charges that take place, in that usejul instrumient.

\section{BY THOMAS BEST,}

CAREFULLY REVISED, CORRECTED, AND ENLARGED.

The pieasant'st Angting, is to sce the fish

Cut with her golden oars, the silver stream

And greedily devour the treach'rous bait.

SHAIIFSPEARE.

\section{Ronoon:}

Printed by T. Plummer, Seething-Lane, Tower-Street,

FOR E. CROSBY AND CO. NO 4, STATIONERS' COURT, PATERN OSTER-ROW,

hod sold by all Iooksellers and Tackle Sellers in the United Hiugdom. 
SIZES OF HOOKS.

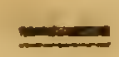

No. No.

Barbel ......... 1 I Loaches ........ 13

Bleak ........ 13 \& Miller's Thumbs .. 13

Bream-Carp .... 3 Minnows ....... 13

Bream White .... 9 S Perch ......... 4

Carp ........ 3 \} Roach .......... 11

Chub ........ 2 \& Rud ......... 9

Dace ........ 12 \{ Ruff........... 9

Eels and Eel-pouts 4 Salmon ........ I

Flounders $\ldots . . .5$ s Salmon-Fry ..... 13

Greyling ....... 10 Tench ......... 3

Gudgeons ..... 12 \{ Trout ......... s 


\section{PREFACE.}

SINCE the first publication of this treatise, upwards of twenty thousand have been sold; by this encouragement $I$ have undertaken to present the public with this new edition, corrected and carefully revised: and where the angler will meet with many recent observations, not to be found in any other halientic production, which I makc no doubt will be equally well received: I may say, without boasting, that it is universally liked, few noble or gentlemen anglers not giving it a place in their libraries. Angling is of very great antiquity, which good old Isaac Walton, the Father of Anglers, has fully demonstrated. Not only kings and princes, but even queens and ladies of the first rank, have taken a delight in this rational and pleasing recreation. In the varions authors who have written on this subject, I have never observed the name of our immortal Bard, Shakespeare, mentioned: he certainly was a lover of this diversion,

A 2 
and no doubt often reclined with his rod in his hand, on the banks of the "sweet-flozing Avon." There is scarce a play of his, wherein there is not some simile or allusion to this amusement. I shall conclude this preface with some quotativns from this Child of Nature.

Leun. Tho' vou perceive me not how I give line. WINTER'S TALE.

Pol. And I fear the angle that plucks our son thither. IEID.

$3 G c n$. And that which angled for mine eyes. InI v.

P.ol. See youl now Yon bait of falsehood takes this Carp of truth. liamLET.

IIun. A man may fish with a worm that hath eat of a King, and eat of a fish that fed of that worm.

IBID.

Ham. Thrown out his angle for my proper life.

IBID.

Cleo. Give me mine angle, we'll to the river, there My music playing far off, I will hetray

Trwny-fin fish; my bentled hook shall pierce 'Their slimy jays: and as I draw them up, I'll think them every one an Anthowy, And say, ah ha; you're caught.

Anthony and Cleopatra.

Char. 'Twas merry when

You wagerd on your angling; when your diver Did hang a salt fish on his hook, which he With fervency drew up.

Clau. Bait the hook well, the fish will bite.

aivch ado about Noturet 
Ur. The pleasant'st angling is to see the fish Cut with her golden oars the silver stream And greedily devour the treacheruus bait; So angle we for Beatricc.

InID.

Maria. Here comes the Trout that must be caught By tickling.

Twelatir Nighr.

I could produce many more examples, to make my observations good respecting our matchless Poet, but these I think are quite sufficient. The Art of Angling opens a wide field for the $\mathrm{Na}$ turalist, including so great a part of Natural Philosophy; so that we not only reap amusement, but instruction from it-And the more we contemplate the works of Nature, the more we shall admire the wisdom of God; and the more roe reverence his wisdom, the greater will be the pleasure ine shall derive from the contemplation of natural oljects!!

$$
\text { T. B }
$$




\section{CONTENTS.}

PARTL

CHAP. 1 .

A Description of Fishes, according to Naturat History, with the best methods of Breeding, and Feeding Carp, \&c.

\section{CHAP. II.}

The best Mranner of Making and Chusing Rods, Lines, Hooks, \&s.

\section{CHAP. III.}

The general Baits used in Angling, where found, and how preserved.

\section{CHAP. IV.}

Of natural, Fly-Fishing, with a Description of Flies generally used, and a choice collection of Rules and Hints to be observed in Angling. 


\section{CHAP. V.}

1 Description of the Fish generally angled for in England and Wales, with the proper Times and Seasons, to fish for them; their peculiar Haunts, spawning Time, and most killing, Baits.

$\begin{array}{lll}\text { The Salmon } & \text { Chub } & \text { Minnow } \\ \text { Trout } & \text { Barbel } & \text { Loach } \\ \text { Greyling } & \text { Eel } & \text { Bull-hiead } \\ \text { Carp } & \text { Roach } & \text { Sticklebach } \\ \text { Bream } & \text { Rud } & \text { Guinniad } \\ \text { Pike } & \text { Dace } & \text { Red Charr, or Welch Torgoch } \\ \text { Perch } & \text { Gudgeon } & \text { The Guilt, or Gilt Charr } \\ \text { Tench } & \text { Pope } & \text { Gold and Silver-Fishes. } \\ \text { Flounder } & \text { Bleak } & \end{array}$

\section{CHAP. VI.}

The most scientific method of making Fishponds, Stews, \&c. to which is added several Arcana in the Art of Angling.

\section{P.ART II.}

\section{CHAP. I.}

Observations concerning Artificial Fly-Angling, with proper Directions for the Angler's Rods, Lines, \&c.

\section{CHAP. II.}

$A$ List of the Materials necessary for an Angler to have, and the best method to make the Palmer and May-fly. 


\section{CHAP. III.}

The Names and the best Manner of dubbing the different Altificial Flies, wohich are generally known, and will kill Fish on any Water from the beginning of March to the end of September.

\section{CHAP. IV.}

A second List of very killing Flies.

\section{CHAP. V.}

The best Rules for Artificial Fly-fishing.

\section{CHAP. VI.}

Of the principal Rivers in Englnnd, and parti cularly of the Thames.

\section{CHAP. VII.}

Of the Game Lawes relative to Angling.

\section{CHAP. VIII.}

Prognostics of the Weather, independent of the the Barometer, extracted from the best Authorities.

\section{CHAP. IX.}

Rules to Judge of the Barometer. 


\section{IBSTT'S}

\section{ART OF ANGLING.}

CHAP. I.

A Description of Fishes, according to Natural History, with the best methods of Breeding; Feeding, \&c.

ANY assert that fishes have not that part deaf. Others are quite of a contrary opinion. However by the first proposition of the second book of Newton's Principia, it is proved that water is a non-conductor of sound; if so, why should animals be provided with organs of hearing, when they live in a medium where sounds cannot be heard?-

Fishes in natural history are animals that live in the water, as their proper place of abode. Naturalists observe a world of wisdom and design in the structure of fishes, and their conformation to the element they reside in.

Their bodies are cloathed and guarded in the best manner, with scales or shells, suitable to their respective circumstances, the dangers they are exposed to, and the motion and business they are to perform. 
The centre of gravity is placed in the fittest part of the body for swiming, and their sliape most commodinus for making way through the water, and most agreeable to geometrical rules.

They have several parts peculiar to themselves; as fins, to balance and keep them upright; an air bladder, or swim, to enable them to rise or sink to any height or depth of water, at pleasure; gills, or branchia, whereby they respire, as land animals do by lungs; the tail, an instrument of progressive motion, which serves to row them forward; eyes peculiarly formed to enable them to correspond to all the conrergencies and divergencies of rays, which the variations of the watery medium, and the refractions thereof may occasion; in which respect they bear a near resemblance to birds.

In most fish, beside the great fin tail, we and two pair of fins upon the sides, two single fins on the back, and one upon the belly, or rather between the belly and the tail. The balancing use of these organs is proved in this manner: Of the large headed fishes, if you cut of the pectotal fins, i. e. the pair which lie close behind the gills, the head falls prone to the bottom : if the right pectoral fin only be cut off, the fish leans to that side; if the ventral fin on the same side be cut away, then it loses its equilibrium entirely: if the dorsal and ventral fins be cut off, the fish reels to the right and left. When the fish dies, that is, when the fins cease to play, the belly turns upwards. The use of the same parts for motion is seen from the following observation upon them when put in action. The pectoral and more particularly the ventral fins, serve to raise and depress the fish: when the fish desires to have a retrogracie motion, a stroke forward 
with the pectoral fin effectually produces it: if the fish resires to turn either way, a single blow with the tail the opposite way sends it round at once: if the tail strike both ways, the motion produced by the donble lash is progressivc, and enables the fish to dart frowards with an astonishing velocity. The result is not only in some cases, the most rapid, but in all cases the most gentle, pliant, easy, animal motion, with which we are acquainted. However, when the tail is cut off, the fish loses all motion, and gives itself up where the water impels it.

Fishes are distinguished into sea, or salt water fish, pisces marini; as the whale, herring, mackarel, zc. river or fiesh water fish, pisces fluviales: as the pize, trout, Sc. and pond or lake fisis: as the carp, tench, \&cc. to which may be added, others which abide indifferently in fiesh water, or salt, as salmon, shad-fish, \&c.

There are also an anıphibious kind, which live indifferently on land or water: as the castor, otter, Sic.

Aristotle, and after him Mr. Willoughby, more accurately distinguish fishes into cetaceous, cartiliganous and spinous.

The cetaceous kind, called also bellua marina, have lungs, and breathe like quadrupeds; they copulate also like them, and conceive and bring forth their young alive, which they afterwarls suckle with their milk.

The cartiliganous sort are produced from large eggs, like birds; which are also excluded the womb like those of birds.

The spinous kind are also oviparoìs; but their eggs are smaller, and they have spinze up and lown their flesh to strengthen it.

Willonghy thinks it would be yet more pro139 
per to divide fishes into such as breathe with lungs, and such as breathe with gills; and then to subdivide those that breathe with gills, not into cartiliganous and spinous, but into vivipurous and oviparous.

The viviparous kind, that breathe with gills, he subcivides intolong, such as the galei and canes, or sharks and $\operatorname{dog} f i s h$ : and broad; such as the pastinaca, raja, \&x. \&xc. the subdivisions of each whereof, he gives in his chapter of cartiliganous fishes in general.

The oviparous kind that breathe with gills, are the most numerous; and these he subdivides into such as are what we usually call flat fish; and such as swim with their backs upright, or at right angles to the horizon.

The plain or flat fish kind called usually plani spinosi, are either quadrati, as the rombi and passeres, or those of the turbot and flounder Find; or longuisculi, as the sola, or sole kind.

Such as swim zoith their backs erect, are either long and smooth, and without scales, as the eel kind, or shorter and less smooth; and these have either but one pair of fins at their gills, which are called orbes and congeneres, or else another pair of fins also on their bellies; which latter kind he subdivides into two kinds: 1. Such as have no prickly fins on their backs, but soft and flexible ones. 2. Such as have prickly fins on their backs.

Those fishes which have only soft and flexible fins on their backs, may be divided into such as have three, $t w o$, or but one single fin there.

No fish but the aselli have three fins oin their backs.

Fishes with two fins on their backs, are either 
the truttaceous, trout kind; or the gobionites, loch, or gudgeon kind.

Fishes with but one soft back fin, are of three sorts. The first kind have one long continued fin, from head to tail, as the hipparus of Rondelctius, \&c.

The second have their fin but short, and placed just in the middle of their back: and these are either marine, as the herring kind; or fluviatile, as those we call leather-mouthed fishes; such as carp, tench, \&c.

Fishes which have prickly fins on their backs, are of two kinds. 1. Such as have two prickly fins on their backs; and in these the interior radii of their fins are always prickly. 2 . Such as have but one prickly fin there.

The English fishes that we have in our ponds, rivers, Sc. are as follow: 1. Cyprinus, the Carp. 2. Tinca, the Tench. 3. Cypinus latus, the Bream, or Bruma. 4. Orfus germanomin, the Rudd, Oerve, or Nersling. 5. Capito ser Cephalus the Chubb, or Chevin. 6. Barbus, the Barbel. 7. Leacissus, the Dace, or Dure. S. Rutilus, seu Rubellio, the Roarch. 9. Alburnus, the Bleak, or Bley. 10. Gobius fluviatilis, the Gudgeon. 11. Cobites fluviatilis barbatula, the Loche, or Loach. 12.Varius, seu phoximuslevis, the Pink, or Minnow.

These twelve are called Malacostomi, or leather-mouthed fishes; because they have no teeth in their jaws, but only deep down in their mouths. To procced. 13. Passer fluviatilis, size amphibious, the Flounder. 14. Anguilla, the Eel. 15. Golio fluviatilis, the Bull-head, or Miller's Thumb. 16. Thymallus, the Gragling, or Grayling, or Umber. 1\%. Salmo, the Siamon. 18. Trutta fluvialilis dum generum, c 3 
the Trout. 19. Albula salmoni similis, the Guinniad. 20. Trutta Salmonata, the Salmon Trout. 21. Trutta Lacustris, the Scurf, or Bull Trout. 22. Umbla minor Gesn, the Red Char, or Welch Torgoch. 23. Carpio lacus Benaci, the Guilt, or Gilt Charr. 24. Lucius, the Pike, or Pickerel. 25. Perca fluviatilis, minor seu aurata, the Ruff. 26. Piscis aculeatus vulgaris, seu pungitius Alberti, the Common Prickle Back Sharpling, or Bansticle. 27. Piscis Aculealus minor, the Lesser Prickle Back. 28. Perca fluviatilis, the Perch.

The eyes of fishes, compared with those of terrestrial animals exhibit certain distinctions of structure, adapted to their state and element. That part of it called the crystalline lense, is much rounder than the eye of terrestrial animals. The eyes of fishes, in their natural and indolent state, appear to be adjusted to near objects, in this respect differing from the human eye, as well as those of quadrupeds and birds. The ordinary shape of the fish's eye, being in much higher degree convex, than that of land animals, a corresponding difference attends its muscular conformation, viz. that it is thoroughly calculated for fiattening the eye.

The $i$ irs also in the eyes of fishes does not armit of contraction. This is a great difference, of which the probable reason is, that the diminished light in water is never too strong for the retina.

In the Eel, which has to work its head through sand and gravel, the roughest and harshest substances, there is placed before the eye, at some distance from it, a transparent hoiny convex case or covering, which, without obstructing the sight, defends the organ. How wise is Providence! 
The share of life which some fish possess, is worthy the notice of every curious angler. - The eel, being cut in pieces, retains life and motion for several hours. A carp will move rigorously some time after the intestines are taken out of its body; but I shall say more on several of these heads in treating of each particular species of fish.

Fish, considered as a food, make a considerable addition to the furniture of the table; and the breeding, feeding, \&c. thereof, is a peculiar art, and it is very necessary, for the satie of economy, that every country gentleman should know something of the method. To this relate the ponds, stews, \&c. which shall be described in their proper places.

It may not be here macceptable to give the reader some general rules on the subject.

\section{RUIA I.}

FOR BREEDING FISIIES.

The quality of the pond, water, Sc. proper to this end, is scarcely determinable by any certain symptom or rule: for some very promising pouds do not prove serviceable that way. One of the best indications of a breeding pond, is when there is a good store of rushes and grazing about it, with gravelly shoals; such as horseponds usually lave; so that when a water takes thus to breeding, with a few Milters and Spawncrs, two or three of each, a whole country may be stoclied in a short time. Eels and perches are of a very good use to keep down the stock of fish ; for they prey much upon the spawn and fry of bred fish, and will probably destroy the 
superfluity of them. As for pikes, tenches, roaches, perches, \&c. they are observed to breed almost in any waters, and very numerously; but eels never breed in standing waters that are without springs, and in such are neither found, nor increase by putting in; yet where springs are, they are never wanting, though not put in.

With respect to the growth of fishes, it is observed, that among Carps particularly, the first year they grow to about the size of a leaf of a willow-tree; and at two years they are about four inches long. They grow but one inch more the third season, which is five inches. Those of four years old are about six inches; and seven after the fifth. From that to eight years old they are found to be large in proportion to the goodness of the pond, from eight to twelve inches.

RULE II.

\section{FOR FEEDING FISHES.}

Observe the following remarks:

1. In a Stew thirty or forty carps may be kept from October to March without feeding; and by fishing with trummels or flezrs, in March or April, you may take from your great waters to recruit your stews: but you must not fail to feed them all the summer, from March to October again, as constantly as cropped chickens are fed; and it will prove profitable.

2. The constancy and regularity of serving the fish, conduces very much to their eating well and thriving.

3. Any sort of grain boiled is good to feed with, especially pease and malt coarse ground: 
the grains after brewing, while sweet and fresh, are very proper; but one bushel of malt, not brewed, will go as far as two of grains; chippings of bread, and orts of a table, steeped in tap-droppings of strong beer, or ale, are excellent food for carp. Of these the quantity of two quarts to thirty carps is sufficicnt; and so fed morning and evening, is better than once a day only.

There is a sort of food for fishes, that may be called accidental, and is no less improving than the best that can be provided; and this is when the pools happen to receive the waste of commons where sheep have pasture; the water is enriched by the soil, and will feed a much greater number of carp than it otherwise would do; and further, the dung that falls from cattle standing in the water in hot weather, is also a very great nourishment to fish.

The best food to raise pikes to an extraordinary size or fatness, is eels: and without them is not to be done, but in a long time. Setting these aside, small perches are the best meat. Breams put into a pike pond, breed exceedingly, and are fit to maintain pikes; who will take care they do not increase over much. The numerous fry of roaches, and other small fish, which come from the greater pools into the pike quarters, will likewise be grood diet for them. Pikes in all streams, and carp in all hungry springing waters, being fed at certain times, will come up, and take their meat almost from your hand.

The best feeding-place is towards the mouth of the pond, at the depth of about half a yard; for by that means the deep will be kept clean and neat; the meat thrown into the water, without other trouble, will be picked up by the fishes, and 
nothing be lost: yet there are several devices for giving them food, especially pease: as a square board let down with the pease upon it.

Where fishes are fed in large pools or ponds, when their numbers are great, inalt boiled, or fresh grains, is the best food. Thus carp may be fed and raised like capons, and tenches will feed as well, but perches are not for a sterv in feeding time.

As to the benefits that :edound from keeping fish, besides furnishing the table, and raising money, your land will be improved, so as to we really worth, and yield more this way than by any other employ whatsoever. For suppore a meadow of tro pounds per acre; four acres in pond, will reurn every year a thousand fed carps, from the least size to fourteen or fifteen inches long; besides pike, perches, tenches, and other fry: the carps are saleable, and will bring sixpence, ninepence, and perhaps one shilling each, amounting in all to twenty-fice pounds, which is six pounds five shillings per: acre.

You should make choice of such a place for your pond, that it may be refreshed with a little rill, or with rain-water running or falling into it ; by so doing fish are both more inclined to breed, and are refreshed and fect the better.

There are many circumstances that conduce much to the feeding of pilics, perches, chubs, carps, reaches, daces, and breams, particularly conveniency of harbour, for those fish that lie amongst weeds and boggy places are the fattest, though not the sweetest; in these kind of places they are secured firom the assaults of thcir numerous enemies, and enjoy a more safe and contented repose; rest and quietness being as natural and helpfil to their feeling ats to other creatures. 
Some waters are more nourishing than others; a thick kind, it it is not foul or muddy, is of a better consistency, and the parts better disposed, and qualified for nutrition than those of a more thin and rarified substance; no element that is pure, and without mixture, is well adapted for nourishment, neither can fishes live by pure water, respiration, or sucking in those slender particles of their beloved element alone, without the concurrence and assistance of some grosser and terrene qualities, which are intermingled with those liquid bodies.

Having mentioned that fishes are exposed to numerous enemies, I shall conclude this chapter by giving the reader a poetical enumeration of them.

A thousand foes the finny people chace,

Norare they safe from their own kindred race:

The pike, fill tyrant of the liquid plain,

With rav'nous waste devours his fellow-train;

Yet, howsoc'er with raging famine pin'd,

The tench he spares, a salutary kind.

Hence too the perch, a like voracious brood,

Tivibears to make this gen'rous race his foud;

Tho' on the common drove no bound he finds,

But spreads unmeasur'd waste o'er all the kinds,

Nor less the greedy trout and gutless eel,

Incessant woes, and dire destruction deal.

rhe lurking water-rat in caverns preys;

And in the weeds the wily otter slays.

The ghastly newt, in muddy streams annoys;

And in swift floods the felly snake destroys;

Toads, for the shoaling fry, forsake the lawn; And croaking frogs devour the tender spawn. Neither the 'habitants of land nor air. (So sure their (loom) the fishy numbers spare!

'The swan, fair regent of the silver tide, Their ranks destrnys andspreads their ruin wide:

The duck her offspring to the river leads, And on tht destin'd fry insatiate feeds: 
On fatal wings the pouncing bittern suars, And wafts her prey ficm the defenceless shores, The watchful halcyons to the reeds repair, And from their haunts the scaly captives bear:

Sharp herns and corm'rants too their tribes oppress, A harrass'd rare peculiar in distress;

Nor can the muse enumerate their foes, Such is their fate, so various are their woes!

\section{CHAP. II.}

The best Mraner of Making and Chusing Rods, Lines, Hooks, \&c.

$7 \mathrm{HE}$ best time to provide stocks is in the winter solstice, when the trees have shed their leaves, and the sap is in the roots, for after January the sap ascends again in to the trunk and branches, at which time it is improper to gather stocks, or tops; as for the stocks they should be lower grown, and the tops the best rush ground shoots that can be got; not knotty, but proportionable and slender, for if otherwise they will never cast nor strike so well, and the line by reason of their unpliablenes, must be much endangered; now when both stock and top are gathered in one season, and as strait as possible to be got, bathe them over a gentle fire, and never use them till they are well seasoned, which will be in one year and four months, but longer keeping them will make them better : and for preserving them when made into rods, both from rotting and being worm-eaten, rub them over thrice a year 
MAKING AND CHUSING RODS, \&C.

with sallad, or linseed oil; if they are bored pour in cither of the oils, and let them soak therewith for twenty-four hours, then pour it out again, and it will preserve them from the least injury. In general the length of the rod is to be determined by the breadth of the river you angle in, but a long rod is always of more use than one too short; provided it is truly made, one of about five yards and a half long you will cxperimentally find to be quite sufficient. When you have taken your stocks and tops from the place that you put them in for seasoning, (where they must have remained sixteen months at least,) inatch them together in just proportion; and let the rod consist of five or six pieces; if you ferre! it, observe that they fit with the greatest nicety, and in such a manner as when put altogether they may not wriggle in the least, but be in pro. portion, and strength, as if the whole rod were but one piece. If you bind them together, it must be with thread strongly waxed, having first cut the pieces with a slope, or slant, that they may join each other with the greatest exactness, and then spread a thin layer of shoemaker's wax over the slants, or a glue, which l have set down in the arcana for the angler's use; afterwards you mustcut about six inches off the top of the rod, and in its place whip on a smooth, round and taper piece of whalebone, at the top of that astrong loop of horsehair; then the whole will be completed, and thus made will always ply with a true bent to the hand. Your fly rods may be made in the same manner; but note, must be much more pliant than the others, and more taper from stock to top. It is of service to them to lay by some. time before you use them.

Your top for the running line must be always 
gentle, that the fish may the more insensibly run away with the bait, and not be checked by its being too stiff:

For all fishes that bite tenderly a rod male of cane, reed, or bamboo, is the best; only be careful when you chuse such a one that it will strike well, and that the medium between the ferrel and the joint that goes in, is not cut too fine; for if it is, when you strike a good fish, it is ten to one you will lose some part of your rod, your line, and of course the fish; a misfortune that has often happened to me, before I was acquainted with the above rule.

A general rod, is one which serves for trolling, dibbing, and the ground; for the former purpose small brass rings must be whipped all the way up it, at about a foot distance, for the trolling line to run through; it may likewise be bored in the stock to hold the tops you are not using; that which you use for the troll must be strong, and have a ring on the top whipped on with a piece of quill, to prevent the line being cut, when the voracious pike runs off with your bait to his hold: one of the others must not be so stiff, which will serve for carps, tenches, \&c. and the other fine and elastic for dace and roach fishing. These kind of rods, which are called bag-rods, and go up in a small compass, are to be had at all the fishing-tackle shops in London.

These rods when put altogether, should be sixteen feet long, which will do for pike or barbel; they should be ringed to a nicety, using a brass-multiplying-winch at the butt, and a strong spike, which will be found of great use; for by retiring from the river, and fixing the rod upright in the ground, (by means of the spike) 
you will keep a tight line, your rod will play with every stroke the fish makes, and you will easily land him with your net.

Rods for roach, dace, tench, chub, bream, and carp, should not have the top so gentle as those for the fly, but pretty stiff, that the rod may exactly ansiver the motion of the hand. Roach and dace ouly nibble, and if you strike not in that very moment (especially if yon fish with paste or any tender bait), you miss them because the top is too pliant.

I with pleasure recommend the angler to that of Mr. William March, of Fleet-street.

angling Line. To make this line, first note, that you are to take care that your hair be round and clear, and free from galls, scales, or frets; for a well-chosen, even, clear round hair, of a kind of glass-colour, will prove as strong as tnree uneven scabby hairs; then put them in water for a quarter of an hour, when made in to lengths, and you will thereby find which of them shrink; then twist them over again; some in the twisting intermingle silk, which is erroneous, yet a line of all silk may do pretty well, though I prefer hair in every inode of angling, except trolling, and then a silk line is best. Now the best colours for lines are sorrel, white, and grey; the two las colours for clear waters, and the first for muddy waters, neither is the pale watery green despicalble, which is made thus; put a pint of strong allum water; half a pound of soot, a small quantity of juice of walnut leaves, in a pipkin, boil them about half an hom then take it ofl the fire, and when it is cold stecp your hair in it; or else boil an handful of marygold flowers, with a rquart of alim water, till a yellow scum arises, then take half a pound of green copperas, with 
as much verdegrease, and beat them together to a fine powder, and put them and the hair into the alum water, and let them lie in it ten hours or more, then take them out and let them dry.* Hair is made brown by steeping it in salt and ale. The best way of forming the hair into lines, is with a new-invented engine, to be bought at any of the shops, and is to be used thus. To trvist links with this engine, take as many hairs as you intend each shall consist of, and dividing them in to three parts, tie each parcel to a bit of fine twine, about six inches long, doubled and put through the hooks which impend from the machine : then take a piece of lead of a conical figlire two inches high, and two in diameter at the base, with a hook at the apex, or point; tie your three parcels of hair into one knot, and to this by the hook hang the weight.

rastly. Take a common bottle cork, and into the sides, at equal distances, cut three grooves; and placing it so as to receive each division of hairs, begin to twist. You will then find the links twist with great evenness at the lead; as it grows tighter shift the cork a lirtle upwards, and when the whole is sufficiently twisted, take out the cork, and tie the links into a knot, and so proceed till you have twisted links sufficient for your line, observing to lessen the number of hairs in each link, in such proportion that the line may be taper.

Never strain your hairs before they are made into a line, if you do they will shrink when used.

Your links thus prepared, tie them together

* Hair or gut steeped in gin and ink, become a curions water.-colour. 
MAKING AND CHUSING HOOKS, \&C.

into al water knot; then cut off the short ends, about a straw's breadth from the knot, and then whip some waxed silk about the knots, which is much better than inclosing them with wax.

Never, either at ground or fly angling, fix any hooks to a line that consists of more than three or four links at the most; but always make a small loop at the top and bottom of your line; the use of the one is to fasten it to your rod, and of the other, to affix or remove your armed hooks. The line should always be leaded according to the rapidity or quiteness of the river you angle in ; therefore, as nearly as you can guess, always lead it in such a manner as will sink the bait to the bottom, and permit its motion, without any violent jogging on the ground. Carry the top of your rod even with your hand, begiuning at the head of the stream, and leting the bait run downwards, as far as the rod and line will permit, the lead aragring and rolling on the growad. No more of the line must be in the water than will permit the lead to touch the bottom; for you are to keep the line as straight as possible, yet so as not to raise the lead from the hottom. When you have a bite, you may perceive it by your hand and the point of your rod and line; then strike gently and "pwards, if you cannot all which way'the fish's head lit's; tut it you can, the contrary way from where it cioes; first allowing the fish, by a little slactening the line, a small time to pouch the bait That is called angling by hand, and is very killing for trout, grayling, sics.

Your rods, lines and hooks camnot be too fine, when you fish for roach and dace; I think the Londoners excelin this part of angling.

$$
\text { c } 3
$$


I shall treat of float fishing under the description of each fish.

As for your fishing hooks, they ought to be made of the best tempered steel wire, longish in the shank, and somewhat thick in the circumference, the point eren, and straight; let the bending be in the shank. For setting the hook, or more scientifically speaking, arming it, use strong but small silk, lightly waxed with shoemaker's wax; and lay the hair on the inside of the hook, for if it be on the outside, the silk will fret and cut it asunder. There are several sizes of hooks, large ones and small ones, made according to the fishes they are designed to take, which, when I come to treat of the different fish, the number of the hook proper for each will be fully expressed.

Ford and Kirby's hooks are excellent ones, but the best I ever had were from Red-bridge in Hampshire.*

Floats, for angling are of divers kinds: some made of Muscovy duck quills, which are the best for slow waters, but for strong streams, sound cork, without fiaws or hoies, bored through with an hot iron, into which is put a quill of fit proportion, is preferable; pare the cork to apyramidical form, grind it smooth with a pumice stone, then colour it according to your fancy. Iloats, whether quill or cork, must be poised with shot, when on the line, as to make them cock; that is to stand perpendicular in the water, that the larst nibble or bite may be apparent.

When a float is split or bruised, there is no remedy for the mischance, but getting a new one, but you may save the plug, and it will serve

"Io mak: hochs, vide the arcuna at the end of the first part. 
for another. But if the water gets in at the top of your float, a little sealing-wax will prevent it: it the plug of your float is loose, pull it out, and fasten it with one of the following cements.

Take bee's wax bruised small, chalk scraped fine, and black rosin powdered, of each an equal quantity; melt them in a spoon, or small tin ressel, and see that they are well mixed; or, take bricli-dust sifted very fine, and common rosin, pulverised; put one part of the bricli-dust to two parts of rosin, and melt them as before directed; dip your your plug in either of these, and put your float immediately upon it. When you join two floats, together let the plug be a little thicker in the middle than at the ends, which ends are to go into the quills; dip one end into the cement, and put one quill upon it, then do the like by the other, and you have a double float: or you make it by dipping the ends of both quills, when prepared, in the ccment, and fixing them together, which, when the cement is cold, will be very strong.

To dye quills red, which for still waters are better than any other floats, take what quantity you please of urine, and put it in as much powder of Brazil-rood as will make it redden a piece of white paper; then take some clean water, into which put an handful of salt, and a little argol, and stir them till dissolved; then boil them wel] in a sauce-pan. When the water is cold, scrape your quills, and steep them in it for ten or twelve days, then dry rub them, and rub them with a woollen cloth.

Every angler should have two panniers,-onc for pike, barbel and chub-the other for trout, perch, roach, dace, bream and guelgeons: however he should be possessed of one, about fourteen inches wide. He should always take out 
with him, lines coiled up. Spare linls. Two worm bags, one for brandlings, \&c. and the other for lob-ivorms. A plummet to fix the depth of the water, of a prramidal form. A gentle box. Floats and spare caps. Split shot. S'loemaliers wax in a piece of leather. Silk. Hooks, some whipped on and some loose. A clearing ring, which is of use to disengagre the hook when entangled. A landing met, to land large fish with. The disgorger, which when a fish has gorged the hook, by putting it down his throat, till you touch the look, at the same time pulling the line, it will easily come away,

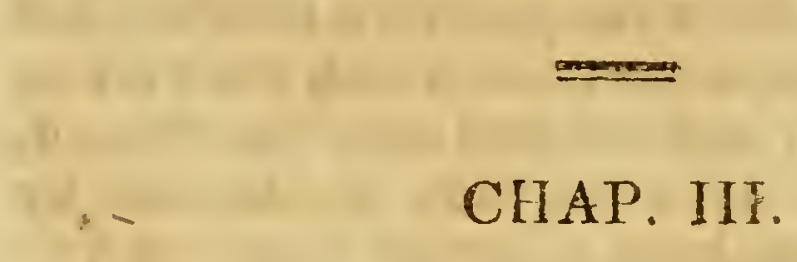

The general Baits used in Angling, where foum? and how" preserved.

THE reader being furnished with the best rules, relative to his rods, lines, hooks, \&ic. I shall give him a list of the baits in general of use in angling; but must desire him to observe, that fish take all sorts of baits, most eagerly and freely, when he presents them to them in such order and manner, as nature affords them, or as they themselves generally gather them.

THE LOB-WORM, DEW-WORM, GARDEN-WOKM, TUF ATCHEL, OR TREACHET,

Found in a garden or church-yard, late in a summer's evening, with a lanthorn; when the 
suminer proves a very dry one, they may be forced out of their holes with the licquor produced by bruising walnut-tree leaves in water: the best of these are those who have a red head, a streak down the back, and a broad tail, from which they derive the name, of squirrel tails.

This is a principal worm for salmon, ('hub), Trout, Barbel, and Eels.

BRANDLINGS, GITT-TAILS, AND RED-WORASS,

Found in old dunghills, rotten earth, cows dung, hogs dungr; but the best are those to be nuct with in tanncrs bark after it is thrown by.

These, especially the two first, are for Trouts, Grayling, Sulmon-smelts, Gudgeon, Perch, Tench, and Brean; the three last take the rel-worm, well-scoured, exceedingly well.

\section{MARSH, OR MEADOWT-WORMS,}

Found in marshy ground, or the fertile banlis of rivers; are a little blueish, require more scouring than the brandling or gilt-tail, and are taken irom Candlemas until Nichaelmas.

This is a choice worm in March, April, and September, for Trouts, Salmon-smelts, Gindgeon, Grayling, Flounder, Brean, and Perch.

\section{TAG-TAIL,}

Found in marled lands, or meadows after a shower of rain, or carly in the morning in Mareh or April, if the weather is mild and temperate; aud is a most excellent batc. 
This is an excellent bait for a Trout, if you angle with it whilst the water is discoloured by. rain.

\section{HOW TO SCOUR AND PRESERVE WORMS.}

Get a quantity of moss, the best is that which is soft and white, and grows on heaths, but as this is scarce to be had in some parts, in lieu of it any kind that is tresh and sweet; rinse it well from the earth that hangs about, and then wring it, (not too dry); put it into an earther pot and squeeze it down hard; then strew the worms upen it, and those that are not bruised, will soon creep into the moss; those that lay at the top you must pick off; cover it close that they do not crawl away, and set it in a cool place in summer and in winter in a warm one, which will prevent the frost from killing them: change the moss every-fourth day in summer, and once a week in winter, or at least let the old moss be taken from them, washed, squeezed pretty dry, and put it to them again. If you want them to be quickly scoured, a little bole armoniac put to them will arcomplish your desire: or you may put them in water for three or four hours, and they will soon be scoured, yet be rery weak, but being put to good moss, they will speedily recover. When the knot near the middle of the brandling begins to swell, he is sick, and should be thrown away" never keep your worms in moss to scour them above ten days, in which time they will be perfectly fit for use.

There is another way of cleansing and preserving worms, recommended by many anglers, and is a very good one for every kind of thern except the lob-zorm: take a piece of very coalse 
cloth, which has never been shrunk in the Fulling-mill, wash it very clean, and let it dry: then soak it in the liquor where a fat piece of fresh beef has been boiled, and wring it out, but not so bard as to press out all the liquor; they lay it in a deep earthen pan, that has al large bottom, and put your worms thereon, that they may crawl in and out and so scour themselres: when they have remained there twenty-four hours, wash out your cloth as before, but do not dry it; then wet it again with some of the same liquor, and having placed your worms thereon, keep them in a close cellar; repeat this every other day during the heat of the summer, and you will not only preserve your worms alive for three weeks or a month, but make them very red, clear, and tough. When you take them out for angling put them into moss that has been well washed and not wrung dry ; and when you come home at night put them again into the pan, by which they will recover and gather fresh strength; take care that there is no salt in the beef liquor, for if there is your worms will purge themselves to death.

Mr. Gay, in his Rural Sports, is particularly partial to the Gilt-tail; as is apparent by the following lines

You must not cvery worm promiscuons use, Indgment will tell, the proper baits to chuse; The worm that draws a long immod'rate size 'The trout abhors and the rank morselflics; And if ton small, the naked fraud's in sight, Ana fear fordids while hunger does invite. Those baits will best reward the fisher's pains, Whose polish'd tails a shining yellow stains :

Cleanse them from filth, to give a tempting gluss,

Cherish the sully'd reptile with moss;

Amid the verdant bed they twine, they toil,

And from their bodies wipe their native suil. 
PHLMER-FLY, PALMER-WORM, TOOL-BED, OR CANISERS,

Found on herbs, plants and trees, where they are bred, if not a perfect caterpillar, yet mdoubtelly a species thereof; they gain the name of wool-beds from their outward parts being woolly; these and the May-fly are the foundation of fly angling.

These are good baits either for Trout, Chub, Grayling, Roach, or Dace.

\section{BOBS,}

Found in sandy and mellow ground, and got by following the plough in autumn, are worms as big as two maggots, have red heads, and their bodies full of soft guts: put them in a tub with some of the mould that you gather them in, keep them in a warm place, and they are an excellent bait from the first of November till the midale of April: you may boil them the morning you intend angling, in milk and water for two minutes, which will make them tough; and put them in a box where gum ivy has been rubbed.

These are choice baits, from the beginning of Novenber until after the middle of April, for Chub, Roach, Dace, Salinon-smelts, Trout, Bream, 'Tench, and Carp.

\section{COF-TURD BOE, OR CLAP-BAIT,}

Found under a cow-turd from the beginning of May to Michaelmas; it is bigger than a gentle, 
but very like one; it is best kept in the same earth you find it in.

This is an excellent bait for a Trout, if you angle with it on the top of the water, with a *bristled hook.

\section{FLAG-WORHS, OR DOCK-WORHS,}

Found among flags, in old pits or ponds, in little husks among the strings or fibres of the roots; are small worms, pale, yellow, or white, as a gentle: these are very good baits.

These are excellent biits for Graylings, T'ench, Bream, Carp, Roach, and Dace.

\section{BARK-WORM, OR ASH-GRUE,}

Found under the bark of an oak, ash, elder, or beech, especially when felled, and they have lain some time, or in the hollow of these trees when rotten; it is to be used from Michaelmas to May or June. It is very full and white, bent round from the tail to the head; and the parts resembling a young dor or humble-bee.

This is an excellent bait for Trout and Grayling; it is very tender, and curious to be baited with.

COD-BAIT, CAD-EAIT, CADIS-WORM, OR CASEWORM, are thus differently called, and are of three sorts.

1st. Found under stones that lie loose and hollow, in small brooks, shallow rivers, or very

* The method of doing this, you will find under the des. cription of the Trout. 
fine gravel, in case or husk, and when fit for use they are yellowish, are bigger than a gentle, with a blackish head. Another sort is found in pits, ponds, ditches, in rushes, waterweeds, straw, \&c. called ruff-coats, or strawworms. The next is a green sort, found in pits, ponds, or ditches, in March, coming in before the yellow ones, which are not to be fished with till A pril, and in July they go out of season; the last sort is to be used in the month of August. When you take them to fish with carry them in woollen bags, for the air kills them.

These are excellent baits fo: all kinds of fish, particularly a large $C h u b$.

\section{GENTLES, OR MAGGOTS, TO BREED AND PRESERVE.}

Take a piece of beasts liver, scotch it with a knite, and hang it up in the shade; when you see it flyblown sufficiently, take it down, and put it into a large pipkin or small barrel; then when you see the gentles have attained their proper size, put some oatıneal and bran to them, and in two days they will be scoured, and fit for use. Thus gentles may be created till after Michaelmas. But if you desire to keep gentles all the year, then get a dead cat, or kite, and let it be fly-blown, and when the gentles begin to be alive and stir, then bury it and them in moist, soft earth, but as free from frost as you can, and these you may dig up at any time when you want to use them: these will last till march and about that time turn into flies.**

* If you want them to be scoured quickly put diry white sand to them. 
Gentles are not only the most universal, but also the most alluring bait, and an angler should nevèr go out a fishing without taking some with him. Trouts have been taken with them, when they have refused all kinds of worms and artificial flies: to every kind of fish they are an acceptable bait, (Pikes and Salmons excepted) but I do not doubt they would be so to them, were it possible to fix them on a hook, large enough to hold the above inentioned fishes.

HOW TO FIND AND PRESERVE CATERPILLAIS, OAK-WORMS CABBAGE WORMS, COLWARTWORM OR GRUB,CRAB-TREF-H'ORA OR JACK, AND GRASSHOPPERS.

Found by beating the branches of an oak, crabtree, or hawthorn, that grow over a public path or highway; or upon cabbages, coleworts, \&c. Grasshoppers are found in short sun-burnt grass, the latter end of June, all July and August. 'To preserve these baits, cut a round bough of fine green-barked withy, about the thickness of one's am, and taking ofl the bark about a foot in length, turn both ends together, in to the form of an hoop, and fasten them with a needle and thread; then stop up the bottom with a bung cork, into this put your baits, and tie a colewort leaf over it, and with a red-hot iron bore the bark full of holes, and lay it in the grass every night; in this manner your cads may be kept till they turn to flies: to your grasshopper put grass. 


\section{PASTES,}

Are variously compounded, according to the angler's fancy but there should always be a little cotton, wool, fine lint, or flnx, to keep the parts together, that wash not off the hooks; the following compositions make very good pastes :

The blood of sheeps' hearts mixed with honey and flour, and worked to a proper consistence: old cheese grated, a little butter sufficient to work it, and coloured with saffron. In winter fat rusty bacon instead of butter. Crumbs of bread, worked with honey, and moistened with gum-ivy water. The inside of a French roll, or crumbs of bread, worked well with clean hands with water alone. What fishes each of these pastes are proper for, the reader will find under the description of each fish, therefore, I shall only make the following observations concerning pastes, which may be of use to young anglers, because founded on experience;-Note, that in September, and all the winter months, when you angle for chubs, carps, and breams, with paste, let the bait be as large as a hazle-nut; but for roach and dace, the bigness of a pea is sufficient: chuse a still place, use a quill float, a small hook, and strike at the first biting of the fish.

When you wish to have your pastes of a yellow colour, use a little Turmerick; when of a flesh, or salmon colour, Vermillion or Red-lead.

BAITS SINGULARLY KILLING TO FISH WITH.

Sheeps' blood, placed on a trencher till it becomes pretty hard, then cut into small pieces proportioned to the size of the hook; put a little salt 
to it; and it will prevent its growing black. Wheat, or malt, boiled soft in milk, and the husk taken off, a good bait either in winter or summer. The ant-fly, found in June, July, August and the beginning of September, in mole-hills or ant-nests, where they breed; take some of the earth, and the roots of the grass which grow upon it, and put all in a glass bottle, then gather some of the lalgest and blackest ant flies, and put them into the bottle; these are a deadly bait for roach, dace, and chub; you must angle with them under water a liand's breadth from the bottom. The young brood of wasps, hornets, and humble-bees, are likewise very good. Also minnows, loaches, sharplings, and bull-heads. Snuils, black and white; the black ones bellies slit to shew the white. Likewise cherries, blackberries, cheese kept a day or two in wet rags, which makes it tough, or steeped in a little honey. Also salmon spain, which must be boiled till it is hard enough to stick on the hook; and if you wish to preserve it, sprinkle a little salt over it, and get a glazed earthen pot, and put a layer of wool at the bottom of it, and then a little salmon spawn upon that; then wool again, and then spawn, and so proceed. alternately till the pot is filled: it is a most destructive bait in the winter and spring, especially if angled with where salmon wie known to spawn; for there every kind of fish resort in order to devour it.

Let all the baits for the Pike be alive on the morning you use them; for stale ones, will not entice him so soon. The best baits are gudgeons, roach, small dace, and bleak. It is a common notion that the pike will not attack the perch, being fearful of the spiny fins, which the percls

$$
\text { 1) } 3
$$


erects on the approach of the former. This may be true in respect to large fish; but I know that small ones, are the most tempting bait that can be laid for the pike: the other fishes are the best for trolling.

\section{CHAP. IV.}

Of Natural Fly-Fishing, with a Description of Flies generally used; and a choice Collection of Rules and Hints to be observed in the Art of Angling.

TATURAL fly-fishing, which comes under the heads of Dibbling, Dapeing, and Dabbing, is a method with which the largest fish are taken, and requires a deal of nicety and circumspection. The general rule in this way of angling is to fish with a line about half the length of your rod; but if there is wind stirring, with as much as it will carry out; but you need hardly ever fish with more than the first length, as dibbling must be performed as near as possible to the bank that you stand on; therefore a long rod and a short line is the best, which you will command with ease, and be able to shelter yourself from the sight of the fishes, behind bushes, stumps of trees, \&c. The line you dib with should be very strong: for when you have struck a good fish you will have a hard bout with him before you kill him, for want of a greater length of line: therefore, whenever 1 dib ilways nse a ringed rod, with a winch for "my 
line fixed on it, by which means I can always keep my line to any length, without the trouble of changing it; and when I have hooked a good fish, can always give him as much scope as I think necessary, and kill him with great ease and certainty; this method I would by all means advise the angler to use, who will be thoroughly convinced of its utility at the first trial he makes. Let the top of your rod be a stiff one. When you see a fish rise near you, guide your fly over him immediately, and he's your own, if the fly you use is strong on the water. When you dib for chub, roach, and dace, move your fly very slow when you see them make at it, or let the stream carry it down towards them; if it be in a still deep, shady hole, draw the fly sideways by them, and they will always eagerly pursue it. The roach takes flies the best a little underwater. The best for the angler's use in this method of angling, are as follow:

\section{OAK-FLY, ASII-FLY, OR WOODCOCK-FLY,}

Found on the body of an oak, or ash, with his head downwards in general, and near the bottom of the tree; it is a brownish fly, and is taken from the beginning of May till the end of August.

This fly is reported to breed in those little balls which grow on the boughs of large oaks, commonly called oak apples; they are provided with a hollow instrument, with which they perforate the tegument of leaves, fruits, or buds, and through the hollow of it, inject their eggs into the wounds which they have made, where, in process of time, they hatch and are nourished: through this discovery, the formation of galls is accounted for. 
BEST'S ART OF ANGLING.

\section{STONE-FLY,}

Found under hollow stones, at the side of rivers; is of a brown colour with yellow streaks on the back and belly; has large wings, and is in season from April to July.

\section{GREEN DRAKE,}

Found among stones by river sides, has a yellow body, ribbed with green, is long and slender, with wings like a butterfly, his tail turns on his back, and is easily taken from May to Midsummer; put the point of the hook into the thickest part of his body, under one of his wings, run it directly through, and out on the other side, then take another and put him on in the sane manner, but with his head the contrary way; they will live so near a quarter of an. hour.

The Green, and Grey-drake, are taken both in streams and still waters, at all hours of the day, while in season; the Stone-fly chiefly in the morning and evening.

\section{GREY DRAKE,}

Found in general where the Green-drake is, and in shape and dimensions perfectly the same, but almost quite another colour, being of a paler and more livid yellow; and green and ribbed with black quite down his body; with black shining wings, diaphanous and very tender: it comes in, and is taken after the green-drake, and when made artificially, as directed in part the $2 d$, for the month of May, kills fish very well. The following: curious account of it from Bowlker, cannot fail to amuse the reader. 
"I happened to walk by the river-side, at that season of the year, when the May-fies (he means the grey sort) which are a species of Libella, come out of the water, where they lie in their husks for a cunsiderable time, at the bottom or sides of the river, near the likeness of the Nymph of the small common Libella, but when it is mature, it splits open its case, and then, with great agility, up springs the new little animal, with a slender body, four blackish veined transparent wings, with four black spots on the upper wings, and the under wings much smaller than the upper ones, with three long hairs in its tail. The husks which are left behind, float innumerable on the water. It seemed to me a species of Ephemera; and I imagined it was the same insect described by Goedurt and Swammerdam, but a few days convinced me to the contrary; for I soon found them to be of a longer duration than theirs. The first business of this creature, after he is disengaged from the water, is flying about to find out a proper place to fix on, as trees, bushes, \&c. to wait for another surprising change, which is effected in a few days. The first hint I received of this wonderful operation, was seeing the Exuvice hanging on a hedge: I then collected a great many, and put them into boxes, and by strictly observing them, I could tell when they were ready to put off their husks, though but so lately put on. I had the pleasure to shew my friends one that I held in my hand all the while it performed this great work. It is surprising to see how easily the back part of the fly split open, and produced the new birth; which I could not perceive partakes of any thing from its parent, but leaves head, body, wings, legs, and even its 
three-haired tail, behind on the case. After it has reposed itself a while, it flies with great briskness to seek its mate. In the new fly a remarkable difference is seen in their sexes, which I could not so easily perceive in their first state, the male and female being then much of a size; but now the male was much the smallest, and the hairs in his tail much the longest. I was very careful to see if I could find them engendering, but all that $I$ could discover, was, that the males separated, and kept under cover of the trees, remote from the river; hither the females resoried, and mixed with them in their flight, great numbers together, with a very brisk motion of darting or striking at one another when they met, with great vigor, just as house-flies will do in a sunny-room: this they continued to do for many hours, and this seemed to be their way of coition; which must be quick and soon performed, as they are of so short a duration. When the females were impregnated, they left the company of the males, and sought the river, and kept constantly playing up and down on the water. It was very plainly seen, that every time they darted down they ejected a cluster of eggs, which seemed a pale bluish speck, like a sinall drop of milk, as they descended on the water; then, by the help of their tail they spring up again, and descend again, and thus continue until they have exhausted their stock of eggs, and spent their strength, being so weak that they can rise no more, but fall a prey to the fish; but by much the greater number perish on the waters, which are covered with them: this is the end of the females; but the males never resort to the rivers, as I could perceive, but after they have done their office, drop down, languish 
and die under the trees and bushes. I observed that the females were most numerous, which was very necessary, considering the many enemies they have, during the short time of their appearance, for both birds and fish are very fond of them, and no doubt under the water they are food for small aquatic insects. What is further remarkable in this surprising creature is, that in a life of a few days it eats nothing, seems to have no apparatus for that purpose, but brings up with it out of the water, sufficient support to enable it to shed its skin, and to perform the principal end of life with great vivacity. The particulax time when I observed them very numerous and sportive, was on the g6th of May, at six o'clock in the evening. It was a sight very surprising and entertaining, to see the rivers teaning with innumerable, pretty, nimble, flying insects, and almost every thing near covered with them. When I looked up into the air it was full of them, as bigh as $[$ could discern, and being so thick, and always in motion, they made almost such an appearance as when one looks up, and sees the snow coming down: and yet this won derful appearance, in three or four days after the last of May, totally disappeared."

\section{IIAWTHORN-FLY,}

Found on every hawthorn bush when the leaves come forth. It is used for dibbing, in some rivers for trouts.

* That there should be a tribe of fies, whose duration extends but to a day, seens at first surprising; but the wonder will increase, when we are told that some of this kind seem to be born and die in the space of a single hour. 


\section{GREAT MOTH,}

Found where there is a little breeze in summer evenings, in gardens; has a great head not unlike an owl, whitish wings, and yellowish body. The chub takes this exceedingly well.

\section{BLACK-BEE OR HUMBLE-BEE,}

Fouind in clay walls, and is an excellent bait for the chub. Some cut off his legs and upper. wings.

THE COCKCHAFER OR BROWN BEETLE.

This is an excellent bait for dibbling, for large tront or chub; they may be seen flying about in hot summer evenings, or found in the day time, on the oak, maple, or ozier; they must be kept in tin boxes, with holes in the lids, with some of the leaves of the trees they are found on.

\section{BLACK BEETLE,}

Found under fresh-horse, or cow-dung; the holes are easily observed, where they creep to deposit their eggs; keep them in some of the earth that you dig up to find them.

N. B. The reader will find the peculiar method of dibbing for chub, under the description of that fish.

\section{RULES AND HINTS TO BE OBSERTED IN ANGLING.}

1st. Every brother angler should be possessed of a great deal of patience and resignation, and 
not be cast down with bad luck, or be elated with good; for the same success cannot always attend him.

2 d. Never angle in glaring colours, for they are the easiest to be discerned by the fishes; always turn out early in the morning, for that is the best time of the day; keep your tackle al ways neat, and let your baits be in the highest perfection.

$3 d$. When you angle shelter yourself as much as possible from the sight of the fishes, for they are timorous and easily frighted; and when you angle for trout, you need never make above one or two trials for him in the same place, for he will in that time either take the bait or let it alone.**

4th. When the nights prove dark, cloudy or windy, you will the next day have but little sport in respect to catching large fishes, especially trouts; for in those nights they range about and devour small fishes; but if the nights are bright and the moon and stars are out, and the days following should be overcast, dark, and gloomy, you may depend on having good sport; for fishes are then as timorous as in sun-shiny days, and never stir from their holds : therefore, having abstained from food all night, they are hungry and eager, and being encouraged by the darkness and gloominess of the day, to range about, they then bite boldly and eagerly.

5 th. If you wish to know what ground baitfishes like best, the first you take open his stomach, and there you will find what he fed on lesst, and bait accordingly.

- This observation holds good for pikes or percl. 
6th. If before you go out to angle, you should imagine, by the lnoks of the weather that it will prove showery, or thunder, always take three or four night lines out with you, and whilst you angle for other fish, lay them in accorling to your judginent; baited with well-sconred Job-wormis, and you may depend on catching large eels, trout, \&c.

Th. The best way to bisit your hook, for this kind of fishing, or for worm-fishing in general, cither with lob-rorms, brandlings, \&c. is thus: if you bait with one worm, put your hook into him somewhat above the middle, and out again a little below the iniddle, having so done draw your worm above the arming of your hook: but note, you must enter the hook at the tail of the worm, and not at the head; then having drawn him above the arming of your hook beforementioned, put the point of yeur hook again into the very head of the worm, till it comes near the place where the point of the hook first came out, and then draw back that part of the worm that was above the shank or arming of the hook : if you fish with two worms, then put the second on before you turn back the hook on the first worm.

sth. If when you are angling in any particular spot, and have had good sport, the fishes should suddenly leave off biting, you may conclude that some of the fish of prey are come to the part you are fishing in; therefore put a minnow on your book alive, sticking it through his upper lip, or back fin; let your tackle be strong in case the pike should be there, but for a certainty you may depend that either he or the perch will take it. But the best way is to have a frimer or two with you, which may be applied 
with great advantage, whilst you angle for other fish.

9th. When you have struck a good frsh, kecp your rod bent, which will prevent him from running to the end of the line, whereby he might break his hold.

10th. In ponds angle near the fords where eattle go to drink; and in rivers, angle for breams in the deepest and quietest parts: for eels, under trecs hanging over binks; for chubs, in deep shaded holes; for perches, inscours; for roaches, in winter in the doess, at all other times where you angle for percics; and for trouts in quick streams.

11 th. It is good angling in whirlpools, under bridges, and at the falls of mills, and in any place where the water is deep and clear, and not dis. turbed with wind or weather; also at the opening of sluices, and mill-dams, and if you go with the course of the water, you will hardly miss catching fishes, that swim upon the stream to seek what food the water brings down with it.

12th. When you fish for roach, dace, \&c. in a stream, cast your ground-bait above your hook, and always remember to plumb your ground.

1.3th. Never trust to the strenghth of your rod or line when you have hooked a good fish, but always use your landing net.

14tin. Your rod must meither be kept too dry nor tuo moist, for the one will make it brittle, the other rotten, and in sultry weather ahways wet the joints of your rod, which will make them adhere; and if by being wet they should stick so that you cannot easily get them asunder, never use force, for then you will strain your rod; but turn the ferrel of the joint that is fast, a few 
times over the flame of a candle and it will separate.

15th. The best times for angling are from April to October, and the best time of the day from threc till nine in the morning, and three in the evening till sun-set. The south wind is the best to angle in; the next best point to that is the west; the cooler these blow in the hottest months, is the best time to fish.

16th. Never angle in an easterly wind, for your labour will be in vain; but you may if the wind blows from any other point, provided not too sharply. Fishes will never bite before a shower of rain; this hint may save you many a wet skin.*

$1 \%$ th. In the morning, if there happens to be a hoar frost, either in the spring or advancing of the season, fishes will not bite that day, except in the evening: and after they have spawned, very ill, till with grass and weeds they have scoured themselves, and by that means recovered their appetite.

18th. The best time for the trout to be taken, and other fishes with the ground-line, is morning and evening, in clear weather and water; but if the day proves cloudy, or the water muddy, you may angle all day long.

19th. The angler may depend on catching store of fishes, in a dark, close, gloomy, or lowering day, if the wind be southerly, and when, as the poet observes,

"The stealing show' $\mathrm{r}$ is scarce to patter heard

"By such is wander thro' the forest walks,

"Beneath thi' umbrageous multitude of leaves."

"Vide the Proguostics. 
Qoth. Lastly, when seated undex a shady tree, on the side of a pleasant river, or moving about on the banks of it, or otherwise pursuing your recreation; when the gliding of waters, the singing of birds, the bleiting of flocks, the lowing of cattle, the riew of delightful prospects, and the various occupations of rural industry, shall dispose you to thought and reflection; let the beanties of nature, the power, wisdom, and goodness of the Almighty, as manifested in the production of his creatures; the order and course of his providence in their preservation, the rewards of a good life, and the certainty of your end, be the subjects of your most serinus meditation!

Having given the reader every necessary instruction, in regard to the breeding and feeding ot fishes; with the best alvice concerning his rods, lines, fluats, hooks, brits, sc. and a set. of rery choice rules, lints, and cautions, I, shall now tell him the best methods of taking the fishes in general angled for in England and Wules.

\section{CHAP.V.}

A Desiription of the Fish generally ungled for in Eingland and Wales, with the proper. Times and Seasons, to fish for them; their peculiar Hasints, spawning Time, and most killing baits, \&s.

\section{SALAMO,}

THE Salmon, according to the opinion of some, breeds in the sea; but that of others seems better warranted, that he bieeds in the I. 3 
clear, sandy, parts of rivers, not far from the mouths thereof. It is entirely a northern fish, being found both at Greenland and Kamschatka, being never so far south as the Mediterranean.

The Salmon-trout migrates like the salmon up several of our rivers, spawns and returns to the sea. The flesh, when boiled is red, and tastes like the salmon.

The White-trout, appears much of the same viature, migrates out of the sea, into the river Esk in Cumberland, from July to September.

The Sumlet is considered by Mr. Pennant as a distinct species, and not as the fry of the salmon, as some have supposed: it seldom exceeds six or: seven inches in length.

They commonly spawn in October, and the young become samlets the following year, and in a few months a large salmon. The milter and spawner having performed their office, betake themselves to the sea, and we are told that when they have been obstructed in their passage, they have grown so impatient, that clapping their tails to their mouths, with a sudden spring, they have leaped clear over weirs and other obstacles that stood in their way; and some by leaping short, have by that means been taken.* If they happen to meet with such impediments that they cannot get to sea, they become sick, lean, and pine away, and die in two years. The principal occasion of their dying is this; the salmon being a fish by nature tender, and very chill, cannot in the winter season en-

* Salmon will sometimes ascend up a river four or fire huilHred miles, only to cast their spawn, fand secure it in banks of wand tiil the young be hatched and exchuded, and theu return to the sea again.

RAY. 
dure the extreme frigidity of the fresh river water, by reason of its tenuity, especially being so lately weakened by spawning; and, therefore, by instiuct, they make the sea their winter habitation, the sea being naturally warm. But if they spawn in the mean time, from thence proceeds a small salmon, called a Skegger, which never grows large. The female salmon is distinguished from the male because its nose is longer and more hooked; its scales not so bright, and. its body speckled over with dark brown spots; its belly flatter; and its flesh not so red; more dry, and less deliciuus to the taste.

The growth of this fish is so extraordinary, that a young salmon being taken at Warington, and which weighed seven pounds on the rth of February, being marked with scissars'on the back fin, was again taken on the 17 th of March following, and was then found to weigh seventeen pounds and a half.

The principal rivers in England for salmon, are, 1st, The Thames, whose salmon bents all others for taste and flavour; the Severn and the Trent; the Lon at Lancaster, about Cockersand Abbey; at Workington in Cumberlund; Sivrelli is Northumberland; Durham, and Nezcastle on Tyne; the Dee in Cheshire; and the rivers $U$ sk and Wye in Monmouthshire. Besides the salnon-ierip in Pembrokeshire, there is another in the river Bars in Irelund: this liver is in the mountains of Mourn in the cousty of Joon, and it passe's through Lough Eaugh, or Lough Siuney, a large lake in the county of Colraine. Mr. Cambden says it breeds sralmons in abundance, abore all other rivers in Errupe, because it is thought to exceed all others for clesrness, in which sort of water sulmons cielight. Lie bites best about three 
in the afternoon, in May, June, July, and August,. if the water be clear and a little breeze of wind stiring: especially if the wind and stream are contrayy. You unust fils for him like a trout, wilh a.worm, fly, ol: mimuore, or lob-r゙or:m is an excellent bait for: him, well scoured in moss, which makes it tough, clear, and lively. When. you have struck him, he will plumge and bounce in. the water very much, therefore it is necessary to. have a strong rod, ringed the same as a trowling. rod, and a winch, with a strong line on it forty yards long, with which length, and a proper. playing him, youmay kill the largest sized one. Ue has not a constant residence like a trout, but removes often, and you should always angle for: him as near the spring-head as possible, in the deepest and broadest parts of the river, near the ground. Put two large iob-roorms on at a time; and you may fish without a float, that is with a running line. Let one yard next to your hook be gimp, and your hook a proper. sized salmon-hook. No.1.

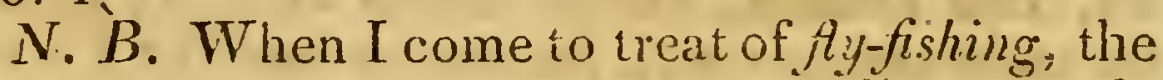
proper flies for the salmon, \&c. Wiil be clearly: expressed..

\section{TRUTTA:}

The Trout; is a delicious fresh-water fish, speckled with red and yellow; coming in and going out of season with the buck, and spawning in the cold month of Oitober and November, whereas all-other fishes spawn in the hot summer months. There are several species of this fish, all valued very much; but the best are the red and yellow; and of these the female distinmuished by a less head and deeper body, is pre- 
ferred; by the largeness of their backs you may know when they are in season, which may serve as a rule for all other fishes. All winter long they are sick, lean, and unwholesome, and frequently lousy. As the spring advances, deserting the still deep waters, they repair to the gravelly ground, against which they continue to rub, till they have got rid of their lice, which are a kind of worm, with large heads; from that time they delight to be in sharp streams, and such as are very sivift; where they wait for minnows, May-fities, \&c. The latter part of May they are in the highest perfection.

The colours of the trout, and its spots, vary greatly in the different waters, and in different seasons; yet each may be reduced to one species. In Llyndivi, a lake in South Wales, are trouts called coch-y-dail, marked with red and black spots, as big as sixpences; others unspotted, and of a reddish hue, that sometimes weigh near ten pounds, but are bad tasted.

In Lough-Neagh, in Ireland, are trouts called there buddaghs, which sometimes weigh thirty pounds.

Trouts (probably of the same species) are also taken in Ulles-water, a lake in Cumberland, of a much superior size to these of Lough-Neagh; these are supposed to be the same with the trout of the late of Geneva. He is usually caught with a zoorm, nimnow, or fly, either natural, or artificial; the different baits for him are the carth-aorm, dung-rorm, and the muggot, or gentle, but the best are the lob-roorm, and brandling. His haunts are, in in purling brooks, running very swift over chalk stones, gravel, \&c. he is oftener taken in the side of the stream, than in it, though the large ones are often caught in the deepest part of it. $H$ 
delights to shelter himself behind large stones, or small banks that hang over the river, which the stream running against, creates a foam; also in the eddies between two streams; his bold is usually under the roots of trees, and in hollow banks in the deepest parts of rivers. When you angle for him at the ground, let the link of your line, next the hook, be the best silk worm gut you can provide; and have a nice elastic rod, which will erable you to strie true, and to feel him when he bites. Argle for him with a running line, and begin at the upper part of the stream, carying your line with an upright hand, and feeling your lead run on the ground about ten inches from the hock, leading your line according to the swifiness of the stream; as before directed. If you bait either with one or two worms, follow the manner of baiting with them which I have laid down in the rules, and you will run on the gionnd without being entangled.

There is a very killing method likenise for a large trout; make a pair of wings of the feather of a land-rail, and point your hook with one or more cudis's; your hook should be bristled, that is, when you whip on your hook, fasten a hog's. brist e under the silis, with the end standing out about $a_{x}$ straw's breadth at the head of the hook, from under the silk, and pointing towards the line, by which means the head of the cadis will be kept close to the wings; angle with a rod about five yards long, and a line about three; cast the wings and cudis up the stream, which will drive it down under the water towards the lower part of the hole; then draw -it up the stream very gently, though irregularly, at the same time shaking your rod, and in a few casts you will be sure to hook him, if there is one in 
the hole. You may angle the same way with two brandlings. Jf you use two cadis's with the wings, run your hook in at the lhead and out at the neck of the first, and quite through the other from head to tail.

The Minnow is the most excellent of all baits for the trout; when you fish with one chuse the whitest, and middled-sired ones, these being the best; and you must place him on your hook in such a-manner, that being drawn against the stream he may turn round. The best way of bating with a minnow is thus: put your hook in at his mouth, and out at his gill, drawing it through about three inches: then put the hook again into his mouth, and let the point and beard come out at his tail; then tie the hook and his tail with a fine white thread, and let the body of the minnow be almost straight on the hook; then try if it turns-well, which it cannot do loo fast. Angle with the point on your rod down the stream, drawing the minnow up the stream by little and litule, near the top of the water. When the trout sees the bait, he will comemost fiercely at it, but be careful not to snatch it away, which at first you may be apt to do; and never strike till he has turned with the bait.

N. B. In this way of angling a ringed rod is to be always used, with a winch for your line, which should have two or three swivels on it; by which means the minnow will spin the better.

Trouts are most voracious fishes, and afford the angler excellent diversion; the passion for the sport of angling is so great in the neighbourhood of London, that the liberty of angling in some of the streams of the adjacent countries, is purchased at the rate of ten pounds per annum. 
These fish shift their quarters to spawn, and, like the Salmon, make up torrards the heads of rivers to deposit their roes.

The rivers most famous for trout are the $K e n$ net near Hungerford in Berkshire; the Stower, in Kent, which runs through Canterbury, and is said to breed the best trouts in the south-east of England, those in the Wandle, near Cashalton in Surry; the Anuerly, in Sussex; the Dove, Wye, Lathkin, and Bradford, in Derbystire; Ribule and $1 r k$, in Lancashire; and in the Usk and Wye, in Nonmouthshire, are accounted excellent trouts; but to speak impartially, no one can absolutely determine in what particular river or brook are the most and best trouts. This, however, is certain, that trouts are better or worse, bigger or less, according to the nature of the soil on which the river runs: pure clear, transparent streams, running on rocks, pebbles, or more especially lime-stones or flints, are experimentally found to breed, and afford the most delicate and best trouts.

The hook No 2 or 3.

\section{TIYMALLUS.}

The Gragling, Grayling, or Umber; this fish has three different names given it, according to the different parts of England where it is found; he is by no means a general fish, and what anglers seldom meet with, except in the rivers Dove and Trent, and some other small streams, particularly in that which runs by Salisbury. The haunts of the grayling are nearly the same of the trout; and in fishing for either of them, 
you may catch both. They spawn the beginning of April, when they lie mostly in sharp streams; in December he is in his prime, at which time his gills and head are blackish, and his belly dark grey, studded with black spots. He bites very freely, but is often lost when struck, his mouth being very tender. The largest that has been heard of was taken near Ludlow: it was half a yard long, and weighed forr pounds six ounces. Angle for him about mid-water, he being much more apt to rise than descend; and when you angle for him alone, and notfor the trout also, use a quill float, with the bait about six or seren inches from the ground. He takes brandlings, gilt-tails, meadow worms, gentles, \&c. but the inost excellent bait for him, in March or April, is the tag-tail.

The hook No. 10.

\section{CYPRIMUS,}

The Carp; is allowed to be the quecn of fresh water fishes (as the salmon is the ling) and lives longer than any other fish (except the eel) ont of its element. They breed several times in one year; but their first spawning time is in May. Mr. Ray assures us that in Holland they have a speedy way of fattening them, by hanging them up in a net in a cellar, and feeding them with biead and milk. Patience is highly nccessary for every one to be cudowed with who angles for carps, on account of their sagacity and cunning; the haunts are in the decpest parts of ponds and rivers, and in the latter where the streans run slow. When the weather in April, May, June, July, and August, is hot and tine, you cannot be too early or late at the sport. 
He seldom refuses the red-rorm in April, the cadis in May, or the grasshopper in June, July, and August. You must angle for him with a strong rod and line, a quill Hoat, and strong gut at bottom; the hook in the medium of size; being a leather-mouthed fish he seldom breaks his hold, if your tackle is strong and you play. him properly. But whenever you intend to fish for him particularly, and in good earnest, orer night lay in a ground-bait of garbage; as chicken's guts, blood mixed with cowdung, or any coarse paste; also ale grains and biood incorporated with clay, and at the same time that you throw any of these ground baits in, plumb the ground to two depths, (for it is best to angle for carps with two rods,) one about mid-water, the other four or fire inches from the ground. The next morning lay your lines in very cautiousiy and success will attend you. Gentles arc very good bait for the carp, also a paste made of honey and bread, and one made with bread and water alone tinctured with red lead, but nothing in my opinion beats a green pea, parboiled, having killed more with that than any other bait.

The Carp is one of the naturalized fish in England, haring been introduced here by Leonard Maschal, about the year 15]4, to whom the English are also indebted for that excellent apple the pepin. The many good things which this island wanted before that period, are enumerated thus:

Turkies, Carps, Hops, Pickrel, and Beer,

Came all into England in one year.

Polish Prussia is the chief seat of the carp (they abound in the rivers and lakes of that country, 
particularly in the Frisch and Curisch-haff, where they are taken of a vast size. They live to a great agc, and grow almost to an incredible weight.

A carp weighing fifteen pounds seven ounces, was some time back taken out of the water in Lord Exeter's grounds at Burghley.

The hooks for this fish No. 3 or 4.

In fine sun-shiny days, carps will often prime about noon, and swim about the edges of a pond, to catch such flies as fall upon the surface of the water: let the angler then ialie a strong rod, and pliable at the top, a strong line, and a hook large enough for a lob-worm; then finding a place fiee from weeds, about the compass of the crown of a hat, let him drop his bait without a float, and with only one large shot upon the line, which he must lodge upon the leaf of some adjoining weed, so that the bait may not be above eight inches in the water; then retiring, but so as to keep his eyc upon the shot, let him wait till he sees it taken away, with about a foot of the line, and then strike: when he has hooked his fish, let him keep him tight, and not suffer him to entangle himself among the weeds: but either draw him out by main force, or pull him into a clear place and there kill him.

N.B. The foregoing method is an excellent one, and great numbers of carp may be talien by it in ponds which are well stoclied.

The hook No.s.

\section{CYPRIAUS LATUSANT BRUMA,}

The Bream; he spawns in .June; his chief residence is in ponds; he is a bony fish and very slow in growth. Irom Saint James's tide to Bartholoncer tide is the best time to angle for him, 
and the best time of the day in that season is, from sun rise, to eight o'clock, in a gentle stream, the water being rather thick, and curled with a good breeze. Some say that breams and roaches will mix their eggs and milt together, therefore the angler in many places will meet with a bastard breed of breams, that never come to be either good or large, but very numerous. There is more time thrown away in angling for this fish, than I think he is worth; bcing in my opinion very insipid. He delights in the deepest and widest parts of the water, and if the bottom is clear and sandy it is the better. His baits are gentles, red-zorms, gilt-tails, and grusshoppers: when he takes your bait he makes for the opposite shore, therefore give him play, for though he is a strong-made fish, he will not struggle much, but in two or three turns, fall on one side, and you may land him very easily. Angle for him with a strong line, with gut at bottom, the hook No. 4 . and throw in the place you intend to angle for bim, a ground bait made of malt, grains, bran, blood, and clay, the night before; and you may fish with two or three lines, plumbed to different depths, and follow the method which is laid down for the carp.

The French esteem this fish highly and have this proverb conccrning him; that he who has breams in his pond, is able to bid his friend welcome. The best part of a bream is his belly and head.

\section{LUCIUS,}

The Pike; is a very long-lived fish, according to Lord Bacon and Gesner; who say he outlives all others. He is called the tyrant of the waters, and will almost seize upon any thing, nay unna- 
turally devoul his own kind. 'These fish were introduced into England in the reign of Heny the VIII. in 1537. They were so rare, that a pite was sold for double the price of a houselamb, in February, and a pickerel for more than a fat capon. He spawns in February or March; the best pike are those that are found in rivers, those in ponds are not near so good: the larger he is, the coarser the food, and so vice zersa. He feeds on small fishes, and frogs, and on a weed called pickerel, from which some assert he derives his being; he is a solitary, melancholy, and bold fish, always being by himself, and ncver swinming in sboals, or in company with other fislies. 'There are two ways of angling for the pike, by the ledger bait and the walking bait. Finst, the colger bait is that fired in one certain place, and which the angler may leave and angle for other fish; of this kind the best is some living bait, as a dace, gudgeon, roach, or live frog. Toapply it, if a fish, stick the hook through his upper lip, or back fin, then fastening it to a strong line ten or twelve yards long; lie the other end to some stake in the ground, or stump of a tree, near the pike's haunt; letting the line pass over the fork of a stick, placed for the purpose, and suspending the hook, by a yard of the line in the water; but so as when the pike bites, the fork may give way, and let him have line enough to go to his hold, and pouch the bait. If you bait with a frog, put the amming wire in at his mouth, and out at his gill; then tie the frog's leg above the upper joint to the armed wire. Secondly, The voulking buit is that which the fisher attends to himselt, and is called trowling, from the French of troller, to move or walk about. Before I 
proceed any further in this mode of angling for the pike, I shall give the angler a description of the kind of rod, line, and hooks, necessary to be used. Your rod must be a strong one, and ringed for the line to pass through, and about three yards and a half long; your line about thirty yards long, wound upon a winch, to be placed on the butt end of your rod, and with which, you may always keep your line to any length; and at the end of your line next the hook let there be a swivel. The hooks that are most general are the two following ones; they are formed and baited in this manner. The first is no more than two single hooks (though you may buy them made of one piece of wire) tied back to back, with a strong piece of gimp between the shanks; in whipping the gimp and hooks together, make a small loop, and take into it two links of chain, about an eighth of an inch diameter; and in the lower link (by means of a staple of wire) fasten by the greater end a bit of lead, of a conical figure, and angular at the point. The second hook may be either single, or double, with a long shank, and leaded two inches up the wire, with a piece of lead about a quarter of an inch square; at the greater or lower end fix to the shank an armed wire about four inches long, and at the top of the wire, about half a yard of gimp, with a loop at the top of that: to bait this hook, you must have a brass needle, about seven inches long; put the loop of the gimp on the eye, or small curve of the needle, then thrust it into the month of the fish, and bring it out at his tail, drawing the gimp and wire along with it, till the lead is fixed in the belly of the bait-fish, and the hook, or hooks, are come to his mouth; then turn the points of the hooks towards his eyes, if 
a double hook, but if a single one, directly in a line with his belly, and tie his tail to the armingwire, very neatly, with white thread. To bait the former, put the lead into the mouth of the bait fish, and sew it up; the fish will live some time; and though the weight of the lead will keep his head downwards, he will swim with nearly the same ease as if at liberty. Either of the former hooks being baited and fastened to the swivel, cast it into the water, and keep it in constant motion; sometimes letting it sink, and at others raising it gradually, chicfly throwing it into the parts of the pond, meer, or river, where his haunts are most usual; as near banks, under stuinps of trees, by the side of bullrushes, waterdocks, weeds, or bushes, but in any of these places you need never make above a trial or two for him, for if he is there he will instantly scize the bait. When you draw your bait near the bank, play it longer there, first deep, then raise it higher and higher by degrees, till you bring it so near the top, that you can see it glitter; take it not hastily out, because he often takes it near the top. When he has taken it give him line, and let him run to his hold and pouch it; allow him in general five minutes law, then strike him, and divert yourself with him as you please. But, if after he has run on with the bait to his hold, and rests there but about a minute, and then runs quickly off with it again, do not strike him until he has rested a sccond time: and not then, until the five minutes are expired, unless he runs off again before they are; which if he does, draw a tight line and strike him immediately; if he resists very much give him line enough, which will soon exhaust his strength; and when you pull him towards you do not do it violently; for 
if you do he will launch and plunge in such a manner, that though he may not be able to break your tacliel, yet he will tear away his hold; nay, even his entrails if he is hooked there; but if you feel him come easily towards you, wind up your line, until you see him; then if he struggles again very much, give him line again; and so proceed till you have killed him; by following which methods you will soon accomplish. The pike bites best from the middle of snmmer, to the end of autumn, about three in the afternoon, in clear water, ruffled with a gentle gale; but in winter all day long; and in the spring he bites early in the morning, and late in the evening. The best waits for him are small roaches, daces, bieaks, Exc. if the day be dark and cloudy; but a gudgeon is the best, if the water is clear, and the day bright and fine. Your live baits should be kept in a tin kettle, with holes made in the lid, thit you may change your water often, which will keep thein alive a long while; your dead ones in a tin box made for that purpose, with bran, whieh dries up the moisture that hangs about them, and contributes to preserve them longer. Angling for the pike at the snap is to let him run a little and then to strike him the contrary way from whence he runs, with two strong jerks; in this method you must use a double spring hook which is to be had at any of the shops, and your tackle must be very strong. 'The snap is best used in March, when they are spawning; it which time they are sick, and lose their stomach; though tirey will then take your bait, but inmediately throw it out of their months; therefore striking them when they first take the bait is the only way to be even with them; which is called augling at snap. The way to bait the snap hook is 
thus; make a hole with a sharp peu-knife in the side of the bait-fish; then put the gimp that is fastened to your hook into it, and draw it out at the mouth, till the spring hook comes to the place where the incision was made; which when it is, plit it into the belly of the fish, then have a piece of lead, about the size of a horse-bean, though of an oval form, with a hole through it from end to cnd, large enough for the gimp to go through; draw it down to the fish's month, then put it in it and sew it up. Or you may make an incision in the skin only, and draw the gimp out at the bone behind the gills, then enter it again under the gills, and bring it out at the mouth, which I think is the best method, becanse the hook has only the skin to hinder its fixing in the pike; whereas in the first method it must pierce through the flesh and skin before it can touch him; and if it is not very large, may hook him so slightly as to spoil all your sport. There used to be a way also of taking pike called huxing, but as the use of trimmers is now so generally known, it would be needless for me to insist farther upon it.

I shall now communicate to the reader a methorl which I have taken more pikes and jacks with than any other way. The hook which you must use, is to be like the first hook that I have mentioned, with this exception only, that the lead of a conical figure must be taken away: then, before you fix the swivel on the botton of the line, put on a cork float that will swim a gudgreon, then put on your swivel, and fix your hook and gimp to it: put a swan shot on your gimp, to make your float cock a little, and of such a weight, that when the hook is baited with the gudgeon, it may do so properly. Your gudgeons must be 
kept alive in a tin kctlle: take one and stick the hook either through his upper lip or back fin, and throw him into the likely haunts before-mentioned, swimming at mid-water. When the pike takes it, let him run a little, as at the snap, and then strike him. In this method of pike fishing, you may take three kinds of fish, viz. pikes, perches, and chubs.

Tlyese fishes are to be met with in most of the lakes of Europe, but the largest are those taken in Lapland, which, according to Schceffer, are sometimes eight feet long: the largest fish of this kind which I ever heard of and saw a drawing of, weighed to the best of my memory, thirtyfive pounds. This I saw in the kitchen of Sir Richard Hill, of Huzokestone, Salop.

At the Marquis of Trentham's canal, at Trentham, a pike seized the head of a swan, as she was feeding under water, and gorged so much of it as killed them both.

Small fishes shew the same uneasiness and detestation at the presence of this tyrant, as the little birds do at the sight of the hawk or oril.

Rules to be observed in trowling. September and October are the best months for trowling, becanse the wecds are then rotten, and the fishes are fat with the summer's fear. March is the best for the snap, because, as I have said before, they then spawn, and are sick, and therefore never bite fieely.

A large bait intices the pike to take it the most, but a small one talies him wilh greater certilinty.

Always, both at trowl and snap, cut away one of the fins, close at the gills of the bait fish, and another at the vent on the contrary side, which makes it play better. 
Let no weeds hang; on your bait, for if they do, the pike will not totich it: and always throw it in to the water gently.

When you have a bite, and the fish goes down the stream, it is commonly a small one; but on the contrary, if he sails slowly upwards with the bait, it is a sign of a good one; great fishes in general bite more calmly than sunall ones; for the small ones snatch and run away with the bait without any deliberation, but old fishes are more wary.

Be careful how you take a pike out of the water, for his bite is venemous; therefore if you have not a landing net, put your fingser and thumb into his eyes, and talie him out that way.

Ioth at trowl and snap, always have one or more swivels on the line, which will prevent its kenking, and make it play better in the water.

Whenever you find your bait-fish water-sopt, change it directly: the hooks for this fish are various.

\section{PERCA FLUVIATILIS,}

The Perch; is boy-backed like a hog, and armed with stitt' gristles, and his sides with dry thick scales. He is a very bold biter, which appears by his daring to venture upon one of his own lind with more eourage than even the ravenous luce. Ile seldom grows above two feet long, spawns once a-ycar, either in February or March, and bites best in the latter part of the spring.

Our Perch and that of Aristotle and Ansonius is the same. It was much esteemed by the Romans, nor is it less admired at present, as a firm and delicate fish; the Dutch, indeed, are 
particularly fond of it when made into a dish called water-sonchy. The perch is a fish very tenacious of life: they are often carried near sixty miles in dry straw, and survive the journey. One was once taken in the Scrpentiue-river, Hyde-park, that weighed nine pounds; but that is very uncommon. The colons are beantiful; the back and part of the sides being of a deep green, marked with five broad black bars pointing downwards; the belly is white, tinged with red, the ventral fins of a rich scarlet; the anal fins and tail of the same colour, but rather paler.

His haunts are chiefly in the strcams not very deep, under bollow banks, a gravelly bottom, and at the turning of an eddy. If the weather is cool and cloudy, and the water a little ruffled, he will bite all day long, especially from eight to ten in the morning, and from three till six in the evening. If there are thirty or forty of them in a hole they may be all caught at one standing: they are not like the solitary pike, but love to accompany one another, and swim in shoals, as all fishes which have scales are observed to do. His baits are minnows, little frogs or brandlings, if well sconred; when he bites give him time enough, and you can hardly give him too much; for as he is not a leather-mouthed fish, without you do, he will often break his hold. Angle for him, if you bait with braudling, with an indifferelit strong line, and gut at bottom, your hook No.4, 5 , or 6 , and about five or six inches from the ground. But if you rove for him with a minnow or frog (which is a very pleasant way) then your line should be strong, and the hook armed with gimp, and the bait swimming at mid-water suspended by a cork tloat. I for my own part al- 
ways use my trowl, that in case a pike should take it, I may be prepared for him. Kcep your milnows in a tin lettle, and when you bait with one, stick the hook through his upper lip or back fin. If you use the frog, stick it through the skin of his hind leg. These directions being carefully attended to, I dare insure the angler success.

The perch is much esteemed in Itaiy, especially when small: Gesner prefers the perch and pilic before the trout, or any fresh fish. The Gerinans say proverbially, more wholesome than a perch of the Rhine!

\section{TINCA,}

The T'nch; (the fishe's physician) so calsed because its slime is said to be very healing to wounded fishes; and what is more strange, the voracious pike is so sensible of his sovereign virtue, that he will not hurt a tench, although he will seize any other fish of his own size that comes in his waly; and when he or any other fishes are sick, they find relief by rubbing themselves against his body. He is a rlelicious tresh water fish; has smail scales, yet very large and smooth fins, a red circle about the cyes, and a little barb hanging at each corner of his mouth. His haunts are. chiefly in ponds amongst weeds; he thives very ill in clear waters, and covers to feed in foul ones; yet his flesh is nourishing and pleasant.

The 'Tench is esteemed, as most delicate food among us; but the Germans dislike it much, and by way of contempt, call it shoemaker. Ciesner even salys, that it is insipid and unwholesome. It does not commonly exceed four or five pounds in weight; but they have been met with of a much larger size. 
They spawn the beginning of July: the proper time to angle for them is early and late in the months of May, June, the latier end of July, and in August. You must use a strong line with gut at bottom. The hook, No. or 3, and a quill float; the depth about two feet. He bites best at red-worms, if you dip them first in tar; at all sorts of parste made up with strong-scented oils, and at one made with the inside of a roll, and honey. Also at cad-worms, lob-zorms, flagworms, gentles, marsh-worms, and soft boiled bread-grain. Besides the river Stour in Dorsetshire, so particularly recommended for plenty of tench and eels, there is BrecknockMere, in Brecknockshire, being two miles in lengih, and as much in breadth, full of perches, tenches, and eels.

N. B. One river tench is worth ten pond.

\section{PASSER FLUVIATILIS SIVE AMPHIBIOUS,}

The Flounder*; may be fished for all day, either in swift streams, or in the still deep, but best in the stream, in the months of April, May, June and July. Your line must be a singlc-haired one, with a small thoat, and the hook, ivo. 6 or $\%$ Let your bait touch the ground, which may be any sort of small zorms, wasps, or genlies. He being a fish but seldom taken with the rod and line, to enlarge on the subject would be totally unnecessary.

\section{CAPITO SEU CEPIIALUS,}

The Chub; is a fish by no means in very much esteem, his Hesh being very coarse, and full of

* The Flounder and all its extensive gronus, of hat fish ; are distinguished from all others by onc invariable characteristic, siz. that of having both the eyes on the same side the liead. 
small hones; yet he afiords good sport to the angler, cspecially to a 'Iyro in that art.

Finis fish lakes its name from its head, not only in the English, but in other languages; it is called Chub, according to Slinner, from the old English cop, a head; the French in the same names, call it testard; the Italians, capitone. It locs not grow to a larese size: we seldom meet with them above five pounds weight; but Salvianus speaks of eight or nine pounds weight.

They span arout the begiming of Apric; and their lacunts are chiefy in large rivors, having clayey or sandy bottoms, in holes, shaded with trees; where many of them in general heep together. He bites best from sun-rising till eight, and from tinee till sun-set. In March and $A$ pril you must angle for the chub with warns, in! June and July, with flies, snails, and chersies; but in August and September, use a paste walde of Sarmesan or Holland cheese, pounded in a mortar with a little butter, and a small quiintity of safiron put to it to make it of a yellow colour. In the winter, when the chub is in his prime, it paste made of Cheshire clecese and turpentine, is very good; but no bait nore lilling for him, than the pilh of an ox or cow's back-ione: you must talie the tough outward skin off very carefully, but takc particular care that you clo not bruise the inward skin; also the brains of the abore animals are excellent for him. Let your line be very strong, with a quill foat on it, strong gub at bottom; tire houk, No. Sor 4 , the depth, in hot werther, mid-water, in coldin near the bottom, and in quite cold weather on the ground. Thle most pleasant way of taking him is by dibbing, which is thus performed; in a hot summer's diay aro toany hole that you know they hamnt, and $6 \stackrel{2}{2}$ 
you will find perhaps thirly or forty of them basking themselves on the surface of the water; then take your rod, which must be very strong and long, your line the same, but about a yard in length: and bait the hook with a grasshopper: you must shelter yourself behind some bush or stump of a tree, so as not to be seen; for the chub is very timorous, and the least shadow will make him sink to the bottom, though he will soon rise again. Having therefore fixed your eye upon the largest and best, drop your bait with great caution before him, and he will instantly take it, and be held fast; for he is aleathermouthed fish, and seldom breaks hold if played properly.

N. B. In dibbing, where you cannot get a grasshopper, any fly, beetle, or moth, will equally answer the purpose.

When you are roving for perch with a minnow you will often take large chub.

The fearful checin loves the shaded stream;

Sharp rills delight the truut, and pools the brean:

In deeps, the speckled sumlet loves to rove,

And inarly swifts, allure the barbel drove;

Unwary roach, the sandy bottom chuse,

Aud carp the weeds, and eels the muddy ooze.

Moses Browne.

\section{$B A R B U S$,}

The Barbel; so called on account of the barb, or beard, that is under his nose or chops, is a leather-mouthed fish; and though he seldom breaks his hold when hooked, yet if he proves a large one, he often breaks both rod and line. The male is esteemed much better than the female, 
but neither of them are very extraordinary. They swim in great shoals, and are at the worst in April, at which time they spawn, but soon come into season again; the places they chicfly resort are such as are weedy, graveliy rising grounds, in which this fish is said to dig, and ront his nose like a swine. In the summer he frequents the strongest and swiftest currents of water, as under deep bridges, weirs, \&c. and is apt to settle himself amongst the piles, hollow places and in moss and weeds. In the autumin he retires into the deeps, where he remains all the winter and heginning of the spring. The best baits for him are salmon-spraton, lob-icorms, gentles, bits of checse wrapt up in a wet linen rag to make it tough, or steeped in honey for twenty-tonr hours, and greares: observe, thit the sweeter and cleaner your baits are licpt the more eager he takes them. You camot bait the ground too much for him, when you angle for him with any kind of garbage: as lob-zorms, cut in piceces, sealt and grains incorpotated with blood and clay, \&c. The carlicr and later you fish for him in the months of June, July, and August, the bettcr. Your rod and line must be very strong; the former ringed, and the latter unust have gimp at the bottom, bat I think twisted gut is better: a ruming phumet must be placed on your line, which is a bullet* with a hole through it: place a large shot a foot above the hook, to prevent the bullet falling on it. The worm will of course be at the bottom, for no flont is to be used, and when the barbel takes the bait, the bullet will lie on the ground and not choak him. By the bending of your rod you will know when be bites, and

* I bave found lately that the fiat plummet is much better. G 3 
also when your hand will feel him give a strong: snatch; then strike him, and he will be your own, if you play him well; but if you do not manage him with dexterity, he will break your tackle. You must have on your rod a winch, and a line on it about thirty yards long.

Barbels are the worst and coarest of freslwater fishes, and seldom eaten but by the poorer sort of people, who sometimes boil them with a bit of bacun, to give them a relish. They are sometimes taken of the length of three feet, and eighteen pounds in weight.

The inost famous places ncar London for barbel-angling are Kingston-bridge, and Sheppertundeeps; but Wallon-deeps, Cherlsey-bridge, Hampton-ferry, and the holes under Conper's-hill are in nowise inferior. You may likewise meet with them at all the locks between Maidenhead and Oxford.

N. B. Their spawn aets as a violent cathartic and emetic. His liver is likewise unwholesome. The hooks for this fish No. 1 or $\cong$.

\section{ANGUILLA,}

The Eel; anthors of natural history, in regard to the eel, have advanced various conjectures; and in some measure contradicted each other entirely on this head, namely: Whether they are produced by generation or corruption, as worms are, or by certain ghtutinous drops of dew, which filling in May and June, on the banks of some ponds or rivers, are by the heat of the sun turned into eels. Abr. Mylius, in a treatise on the origin of animals, describes a method of producin e them by art. He says, that if you cut up two turfs covered with May-dew, 
and lay onc on the other the grassy side inwards, and thus expose them to the lieat of the sun, in a. few hours there will spring from them an infinite quantity of eels. The iluctrine of spontaneous or equivocal gencration is now universaliy exploded; and all the phenomena that seem to supportil are accounted for on other principles. These conjectures are therefore all nonsense; tor the immediate generation of Lels, has been sutficiently proved to be effected in the ordinary course of nature, and that they are vivaporous. Eels are distinguished into four kinds, viz. the silier cel: a greenish eel, called a grey: a blackish eel, with a broad flat head; and lastly an eel, with reddish fins. The eel's haunls are chiefly amongst weeds, under roots and stumps of trees, holes, and cleftsin the earth botinin tinc banks and at bottom, and in the plain mud; where they lie with only their heads out, watching for prey: also about flood-gates, wears, bridges, and old mills, and in the still waters that are foul and muddy; but the smallest eels are to be met with in all sorts of rivers and soils. 'They conceal themselves in the winter for six months in the mud, and they seldom rove about in the summer in the day time, but all nightlong; at which time youmay talie a great number of them, by laying in nighilines, fastened here and there to banks, stumps of trees, src. of a proper length for the depth of the water, leaded so as to lie on the ground, and a proper eel-hook whipped on each, baited with the following baits, which he delights in, viz. grrden-z"orms or libs, minnoxs, heu's-guts, fish garbuge, loaches, small gudgeons, or miller's thumls, also small roaches, the hook being laid in their mouths. 'There are two mays to take' them in the day-time, called sniggling and bobbing. Sniggling is thus performed: take a 
strong line, and bait your hook with a large lobworm and go to such places abovementioned where eels hide themsclves in the day-time, put the bait genily into the hole, by the help of a cleft stick, and if the cel is therehe will certainly bite, le him tire himself by tugrging, before you offer to pull him out, or else he will break your line. The other method is called bobbing. In order to perform this you mast scour sone larige lobs, and with a needle run a twisted sill, or worsted, through as many of then from end to end, as will lightly wrap a dozen times round your hand; make them into links, and fisten them to stiong packitread or whip-cord, two yands long, then make a knot in the line about six or eight inches from the woms, afterwards put three quarters of a pound of lead, made in a pyramidal form, on the cord; the lead must be made hollow three parts of the way up it, and then a hole must be bored through it, big enough to put the cord through and let the lead slicie down to the knot. Then fix all to a managcable pole, and use it in muddy water. When the fishes tug, let them have time to fasten, then draw them gently up, and hoist them quick to shore: A boat called a punt is very useful ia this kind of fishing. Some use an eel spear to catch eels with, which is an instrument with three or four forks or jagged teeth, which they strike at random in to the mud.

Common eels grow to a large size, sometimes so grent as to weigh fifteen or twenty pounds, but that is extremely rare. The eel is the most universal of fish, yet is scarce ever found in the Danube, thongh it is very common in the lakes. and rivers of Upper, Austria. 
The Romans held this fish very cheap, probably from its likeness to a snake,

"For you is hept a sink-fed snake-like eel."

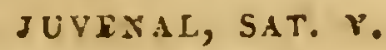

The Conger Eiel, grows to an immense size: they have been taken ten feet and a half long, and eighteen inches in circumference in the thickest part. The best way to kill eels, is to strike them on the navel.

The rivers Stazuer in Darsetshire; Ankham in Lincolnshire; and $I r k$ in Lancashire; are famed by their respective neighbours for very esce!lent eels. Mr. Pope has celebrated the ritor in ennet, in Berkshire, on the sane account in his Windsor Forest.

The Kennet swift, for silver eels renown'd.

In Ramsey-mere, in Finntingdonshire, are a great quantity of eels and large pikes, which they call Hagest; but Cambridgeshine boasts of having? the most and best eels, if you credit the natives.

Eel-pouts, another fish somewhat resembling the eel, but more estecmed, are also found in some rivers. Their hanits are the same as the cel's, and they are to be taken in peals of thunder and heavy rain, when they leave their holes. The best bait is a small gudgeon. Hooks, the double or single ones.

IIUTILUS, SEU RUBLLIIO,

The Roach; is as foolish as the carp is crafty; he is by no means a delicate fish; the river unes 
are much better than those bred in ponds. They spawn in May, and will bite all day long, if the weather is not in either of the cxtremes, on the top of the water. Their haunts are chiefly in sandy or gravelly deep waters: delighting to be in the shate. In April their baits are cals and aorins. In summer, white snails or flies. In Attumn, a paste made of fine white bread, moukced in rour hands with water, and a little cotton added to it, to keep it from washing off the hook. In minter gentles are the best bait for lim; you should fish with a line made of single hairs, a cuill float, and the lead about a foot from the hook; and when you angle for roach always cast in a ground bait, made of bran, clay, aid bread, incorporated togcher, and when you angle with tender baits, always stilite at the lenst nibble that is apparent. Spronted malt, the young brood of wasps, bees lipt in blood, and the dried blood of sheep, are nostrums in this kind of angling.

Bread being now, at so cxtravagant a price, to use it as a ground-bait, when our poor stand so much in need of it, worid be presumptions and wicked. Therefore Tet the considerate angler content himselfwith moulding bran and clayey soil well together, and throw it in, in small balls, about the size of a nonpareil.

The largest roach in thiskingdom are taken in the Thames, where many have been caught of two pounds and a half weight; but roach of any size are hard to be taken without a boat.

'The people who live in the fishing towns along the banks of the Thames, have a method ut

Coase bran and flour make an excelient ground bait, but thry must not be too much moulded. 
dressing large rouch and dare, which it is said, renders lhem a very plcisant and savnury food; it is as follows: without scaling the fish, lay lim on a gridiron, over a slow fire, and strew a bitle flonr on him; when he begins to grow biown make a slit, not more than skin deep, in his back, from head to tail, and lay him on argain; when he is broiled enough, the skin, scales and all, will peal off and leave the flesh, which will be by that time very firm and perfectly clean; open the belly, take out the insirle, and use anchovy and butter for sance.

Red-puste is an excelient bait colored with vermilion or red-learl, as I have before laid dorn, but it is best to take wibh you guntles, white-pasle, and their ollier bats, as they are very fond of change, and will refinse one minute what they will take the next. Their hooks No. 11 of 12.

\section{ORFUS GERMANOZUM,}

The Rud, Oerve, or Nersling; I think is the bastard-roach which old $W^{T}$ alion speaks of ; they are found chiefly in the channel, near Oxtord, in the fens, near lolderuess. It appears to be the same fish with the sha!low of the Cim.

The rnd, a kind of roach, all tinged with gold, Strnue, broad, and thick must lovely o behuld, High on the surlace will with freedum bite At smalired-worms, or lles, his life lelight; But angler, when you've houken him, then takc care, Ia struggles long, and breaks the single bair.

NIUSES BROW הE.

\section{LIECTSSUS,}

The Dace or Dure; this fish, and the roach, are much of the same kind, therefore the direc- 
tions given for one will serve for the other. They spawn about the midrlle of March, and will take any fly, especially the stonecadew-fly, May-fly, the laiter end of April and most part of May; and the ant-fly in June, July, and August. When you angle for the dace with the ont-fly under water, let it be about wo hands breadth from the ground. They never refuse a.fly in a warm day on the top of the water. The best bait for them in the winter, is the earth bob, it is the spawn of the beetle, and is to be found by following the plough in sandyish grounds; put them into a vessel with some of the earth from whence they are taken, and use them all the winter as an excellent bait, as I have before mentioned in the description of baits. As for your line, sc. the directions given for the roach, will scrve in all respects for the dace or dare.

Dace may be also taken with Aesh-flies, upon the surface of the water; into whose backs, between the wings, you must put yon hook, which should be very small: they bite in the morning and evening; you must then provicle a cune-rod, which is the lightest of any, and let it be seventeen feet, at least, in leng'h, and your line, which should from the midrle downwards, consist of single-hairs, be a little longer than your rod; then provide a sufficient quantity of house-fies, which keep in a phial, stopped with a cork. With these repair, especially about seven or eight o'clock in a summer's evening, to a mill-stream, and having fixed three or four hooks, with single hair-links, not above four inches long to your line, bait them with the flies, and angle up the surface of the water on the smoothest part, at the end of the stream; the dace will rise frecly, 
especially if the sun does not shime on that palt of the watel where you cast the flies, and you may lake two or three al a time. 'This sport wil! continue as long as ray-licht will permit you 10 see the flies. In the same mamner dace will also risc at the unt-fiy upon the surface of the water, if used in the morning at the foot of a current or mill-stream, or on the scour before the sum comes on the water. If the water is high, so as to be almost equal with its banks, tritie your fly-rod, and fasten to your lod an arlificial-fly, called the caterpillar-fly, or a small red-palmer, then take a large yellow genle, the yellower the better, run the hook through the skin of $i t$, and draw it up to the tail of lhe Hy: this beinc done, whip it on the surface of the water, and if you are rliligent and expert, jou will have good diversion. If you angle where two mill-streams are going at the same time, let it be in the eddy betwcen the two streans; first matie use of your plummet; if the water is deep, angle within a foot of the buttom, and perhaps you will find but poor sport; but if it proves to be shallow, that is, about the depth of two feet, or not exceeding thrce, your sport may be better; bait your hook with three large geules, use a cork float, be very attentive and strike at the very first bite; if there are any large dace in the mill-poril, they will resort io the eddy between the wwo streallis.

This fish, like the roach is gregarious, baunts the same places, is a great breeder, very lively, and during the sumner is very fond of frolicking near the surface of the water; it is seldom above ten inches long, and has been taken of one pound and a half weight.

N. B. Whenever you fish for roach or dace, 
at ground, without you use a ground-bait, the attempt is almest useless; after great heats, when the weather getscool, you will be sure to have good sport.

The hooks, No. 11 or 12.

\section{GOBIUS FLUVIATILIS,}

The Gudgeon; is a fish that affords the young angler an amazing deal of diversion; being one that bites very free, and when struck is never lost, because he is a leather-nouthed fish. They spawn three or four times in the summer, and their feeding is like the barbel's, in the streams and on gravel, slighting all manner of flies. Their baits are chiefly wasps, gentles, and cads, but the small red-worm is best. When you angle for them, be provided with a gudgeon-rake, with which rake the ground every ten minutes, which gathers them together. A single-haired line is best, with a quill or cork float, according to the rapidity of the stream ; your hook, No. 8 or 9 , and your bait on the ground. You may angle for him with a running line, by hand, without a float.

The gudgeon is of a small size; those few, however, that are caught in the Kennet and Colc, are three times the weight of those taken elsewhere. One was once taken near Uxbridge, that weighed half a pound.

The author "On Angling in the River Trent," gives us a new method of catching them: he first desires us, "never to continue in the reater long, though he has been in it for six hours together;" he then observes with his usual circumspection, "that the best wuy of catcling them, is by going into the rater, and stirring up the sand and gravel." This surely may be termed gud- 
geon-hunting more than gudgeon-fishing: Perhay: they ure of a different species in the livent thun in I'luanes, sic. \&ic.!!

PERCA FLUVIATILS, MINOR SEU AURATA,

The Pope or Ruff; this fish with a doulle name, is small, and rarely grows bigger than at gudgeon; in shape very like the perch, but is better food, being in the taste as pleasant as any fish whatever.

It is armed with spines like the perch, but has only one back fin. It is of a dirty green alinost transparent, and spotted with black. It seldom exceeds six inches in length.

His haunts are in the deepest running parts of a gravelly river, the exact bottom whereof, having found by plumbing, bait your hooks with small red-rorms or brandlings; for you may angle with two or three, and have excellent sport. He bites very greedily, and as they swim in shoals, you maly catch twenty or thirty at one standing, in a cool, gloomy day. Always bait the ground with earth, and use the same tackle as for the gudgeon. The river Yare in Norfolk, is almost peculiar for plenty of ruffs.

Hook, No. 9.

\section{ALBURNUS,}

The Bleak or Bley; on account of its eagerness to catch flies, is called by some the riverswallow, and by others the fiesh-riater sprat, because of its resemblance to the seatsprat. He bites very eagerly at all sorts of zorms, flies, pastes, and sheep's blood. You may fish for him with six or seven small hooks at a time. He is 
an excellent fish to initiate a young angler in Hy-tishing, by his whipping for then in a not sumner's erening, with a small artificial black gnat. Your tackle must be fine and neatly formed. He is a capital bait for the pike.

Hook, No. 13.

The bleak seldom exceeds five or six inches in length; artificial pearls are made with the scales of this fish, and of the dace. They are beaten into a fine powder, then diluted with water, and introduced into a thin glass bubble, which is afterwards filled with wax. The French were the inventors of this art. Dr. Lister, says, that when he was at Paris, a certain artist used in one winter, thirty hampers full of fish in this manuficture.

\section{VARIUS, SEU PROXINUS LAVIS,}

The Mimore or Pink; though one of the smallest fishes, is as excellent a fish to eat as any of the most tamed. They are generaily found in Mareh and April, and remain till the cold weather compels them to retire to their winter-quarters. He is of a greenish, or wavy sky colour, his belly very white, his back blackish; and is a most excellent bait for any of the fish of prey : namely, the pike, trout, perch, Sc. His baits are small red-worms, rasps, cads, \& c. If you can catch enough of them, they will make an excellent tansey, theirheadsand tais being cut off; and fried in eggs, with a sauce made of butter, sugar, and verjuice. The smalles of hooks. The minnow is it most killing bait tor the large trout, perch, and chub. 


\section{COBITES FLUTIATLIS BARBATULA,}

The Loach or Loche; this fish is very sinall, but eats very well, and is nomishing food for sick persons.

The loach is the first gonius of abdominal fishes, or those which have the ventral fius behind the pectoral, that is, nearer the tail, as in the salinon. It never exceeds four incbes in lengtir.

He is found in clear swift broolis and rivulets, and his food is gravel. He is bearded like the barbel, and freckled with black and white spots. Yon may take him with a red-wornt, at grounci; he delights to be near the gravel, therefure is hardly erer seen on the top of the water.

The smallest of hooks.

\section{GOBIO FLUVIATILIS,}

The Bull-head, or Miller's-!huml; this fish, on account of its ugliness, is in some places called the fresh-zotex devil; he has a brond head and a large mouth, no teeth, but his lips are like a file, with which he nibles at the bait. Tley spawn in April, and are full of spawn most of the summer.' Their haunts in summer are chicfly in holes, or amongst stones in clealr-water; but in winter they lie in the mud like the eel. The worst of anglers may take this fish; for if you look above the water in a hot day, you may sce him sumning himself on at fiat stone, put your hook upon it, baited with a small red-worm, and he will take it directly. The tase of this fin is very goorl.

liouk, No. 13. 
PISCIS ACULEATUS YULGARIS, SEU PUNGITIOB ALBERTI,

The Sticklebrack, Sharpling, or Banstickle; this fish, with thrce names, as he is called by in different connties, is a small prickly fish, and not worth the angler's notice, in regard to himself, but that he is an excellent bait for the trout, who will take it sooner than the minnow. His prickles nust be broke off, and baited according to the directions given for baiting the minnow, under the description of the trout.

In the fens of Lincolnshire, they are found in such numbers, that they are used to manure the land. There are three species of them, the common, or three spired, the ten spined, and the fifteenspined. The two first seldom reach the length of two inches, the latter sometimes grows to that of six, and is found in the sea only.

N.B. The tackle, baits, \&c. for this fish, and the foregoing ones, must be the same, and rery fine.

There are three fishes which I omitted in the first edition, and what anglers in general seldom meet with, because they are local, and peculiar to certain waters; but as they are held in high estimation where they are taken, I shall describe them as well as I can for the reader's inforniation.

*ajbula salinoni similis,

The Guinniad; according to Camden and others, is peculiar to Pemble-Mere in Cheshire. "The

* Fulse-acuter fishermen, in 1775 , tock near eight thousand at ane curaght. It is abcut cleven inches long. 
river Dee (says this author) which ruas by Chester, springs in Merionethshire, and it runs towards Chester; it passes through the said Pemble-More, which is a large water, and it is observed, that though the river Dee abounds with salmon, and Pemble-Mere with guinnial, yet there are never any salmons caught in the Mere, nor any grimiads in the river."

UBRRA HINOR GESY-THE RED CHARR, OR WEELCHT TORGOCH.

The red charr is a fish whose make is longer and more slender than that of a trout, for one of about eight inches long was no more than an inch and a half broad. The back is of a grenish olive, spotted with white. The belly, about the breadth of half an inch, is painted with red, in some of a more lively, in others of a paler color, and in some, especially the female, it is quite white. The scales are small, and the lateral lines straight. The mouth is wide, the jalws pretty equal, except the lower, which is a little shallper and more protuberant than the upper. The lower part of the fins are of a vermillion dye. The gills are quadruple, and it has teeth both in the jaws and on the tongue; in the upper jaw there is a double row of them. The swimmingbladeler is like that of a trout; the liver is not divided into lobes; the gall-bladder is large; the heart triangular; the spleen small and blackish; and the erggs of the spawn large aud round. The flesh is more soft and tender than that of a trout, and when boiled can scarcely be allowed to be red. It is in the highest esteem where known, and in Wales is accounted the chief dish at the tables of people of fashion 
The chief place in Eingland where this fish is taken is Winunder-Mere: but in Wales they are to be had in fire diferent places, viz. Llamberris, Llia-Umber, Fesiniog, and Beltus, in Caernarvonshire, and near Casageddor, in Merionethshire. Li this last county hey are smalier than in the former, and are taken in October; but in Carnarvonsicire, in one of the lakes, they are caught in November; in another in Deconber, and in the third in Junuary, and when the fishing in one ends, it begins in another. Dr. Leigh says the Charr, in Consington-Mere, which is not far from Winander-Mere, are much better, but there are reasons to suppose he was prejudiced in this article. According to Camden, the latter Mere is the larest standing water in this kingdom, being ten miles in length; and some say it is as smooth at the bottom, as if it was paved with polished marble. They swim together in shoals, and though they appear on the surface of the water in the summer-time, yet they will not suffer themselves to be taken, either with the angle, or with nets; therefore the only season for fishing is when they resort to the shallow parts of the lakes to spawn: at these times they set trammelnets baited, and leave them for whole days and nights, into which the fish enter of their own accord.

\section{* Carpio lacus benaci-teje guilt, on GILT CHARR.}

The Latin writers called the Gilt Char, Carpio lacús Benaci, because they imagined it was

* The inbabitants of Westmoreland distinguish the Charrs into different kinds according to their colors; but they appear to be rather varjeties. 
only to be met wirh in that particular lake, where it is called Roetel; but it has since appeared to be the same figh with our gilt charr, which is bred in Winander-Mere; rin the county of Westmoreland. It is proportionably broader than the trout, and the belly is more prominent; but its length, when greatest, never exceeds twelve inches: the scales are small, the color of the back is more lively than that of the trout, and is beautified with black spots, the belly and sides, beneath the lateral line, are of a bright silver color; the skull is transparent, and the snout blueish: it has teeth il: the lower jaw, on the palate and the tongue; the swimmingbladder is extended the whole length of the back, and the gall-bladder is large. The flesh of the gilt charr is red, and is accounted so very delicious amongst the Italians, that they say it excels all other pond and sea-fish whaterer; and they esteem the nature of it so wholesome, that they allow sick persons to eat it.

Some have doubted whether the Welch and Finglish fish, are of the sime kind or not; but Mr. Ray thinks there is no room to make a loubt of it. The Welch name Torgoch, signifies a red belly, which distinguishes the Red Charr properly enough; the Gilt $C$ :harr is, indeed, quite a different species, and is about twice as small as the red: the belly of the former is red, the flesh whice, and the spots on the back white likewise; whereas the belly of the latter is of a silver color, the fleshred, and the back is spotted with black.

"The charr and guimiad never change their shires, "But live in Winander and Pemblc-sleers." 
GOLD AND SILFER FISHES.

Thes? fish are quite naturalized in Europe, and breed as fieely in the open waters as the common carp. They were first introduced into England about tise year 1691, but were not generally known till 17@s, when a great number were brought over, and presented first to Sir Matthew Dekker, and by him circulated round the neighbourhood of London, whence they have been distributed to most parts of the commtry. In China the most beautiful kinds are taken in a small lake in the province of Che-thyang. Every yerson of fashion keeps them for amusement, either in porcelain vessels, or in the small basons that decorate the courts of the Chinese houses. The beauty of their colors, and their lively motions, give great entertainmeri, especially to the ladies, whose pleasures, by reason of the cruel policy of that country, are extremely limited. In form of the body, they bear a great resemblance to a Carp. They have been known in Europe to arrive at the length of eight inches; in their native place they are said to grow to the size of our largest herring. Their nostrils are tubular, and form a sort of appendages above the nose; the dorsal fin and the tail vary greatly in shape; the tail is naturally bifid, but in many is trifid, and in some even quadrifid; the anal fins are the strongest characters of this species, being placed not behind one another as in other fish, but opposite each other, like the ventral fins. Their colors vary greatly; some are marked with a fue blue; with brown, and with bright silver; but the general predominant colour is gol'd, of a most amazing splendor; but their 
cólors and form need not be dwelt on, since those who want the opportunity of secing the living fish, may survey them expressed in the most animated manner- in the works of $\mathrm{Mr}$. George Edwards.

\section{$=$ \\ CHAP. VI.}

The most scicntific melhod of mating Fishponds, Stews, \&c. to which is added several Arcana in the Art of Angling.

$T$ is agreed, that those grounds are best that are full of springs, and apt to be moorish: the one breeds them well and the other preserves them from being stolen.

The situation of the pond is also to be considered, and the nature of the currents that fall into it; likewise that it be refreshed with a little brook, or with rain-water that falls from the adjacent hilly ground. And that those ponds which receire the stale and dung of horses, breed the largest and fattest fishes.

In making the pond, observe that the head be at the lowest part of the ground; and the trench of the flood-gate, or shice, has a grood swift fall, that it may not be long in emptying.

If the pond carries six feet of water it is enough; but it inust be eight fect-deep, to receive the freshes and rains that should fiall into it.

It would be also advantageous to have shoals on the sides, for the fishes to sun themselves in, and lay their spawn on; besides in other places 
certain holes, hollow banks, shelves, roots of trees, islands, \&c. to serve as their retiring places. Consider, further, whether your pond be a breed$\mathrm{er}^{3}$; if so, never expect any large carps from thence; the greatness of the number of spatin overstocking the pond.

ivi. 'I ull, in order to prevent the excessive increase of fish in his ponds, first practised castration on them, which made them grow larger than their usual size. But I think the operation peculiarly crnel, and the purposes of it only a detestable piece of Apician refinement.

For large carps a store-pond is ever accounted best; and to make a brecding-pond become a store-pond, see what quantity of carps it will contain; then put in all milters or all sparners; whereby in a little time you may have carps that are both large and exceedingly fat. Thus by putting in one sex, there is in impossibility of the increase of them; yet the roaches, notwithstaniing this precaution, will muliply. Leserve some great waters for the head-quarters of the fishes, whence you may take, or wherein you may put, any quantity thereof. And be sure to have stews and other auxiliary waters, so as you may conrey any part of the stock from one to the other; so to lose no time in the growth of the fishes, but employ your water as you do your land, to the best advantage. View the grounds, and find out some fall between the hills, as near a flat as may be, so as to leave a proper current 'for the water. If there be any difficulty of judging of such, take an upportunity, after some sudden rain, or breaking up of a great snow in winter, and you will plainly see which way the ground casts, for the water will take the true fall, and run accordingly. 
The condition of the place inust cletcrmine the quantity of the ground to be covered with water. For example, I may propose in all fiftecn acres in three ponds, or eight acres in two, and not less; and these ponds should be placed one above another, so as the point of the lower may almost reach the head or bank of the upper, which contrivance is no less beautiful than advantageous.

The head, or bank, which by stopping the current, is to raise the water, and so make a pond, must be built with the clay or earth taken out of the pan or hollow, dug in the lowest ground above the bank: the shape of the pan to be a half oval, whereof the flat to come to the bank, and the longer diameter to run square from it.

For two large ponds, of three or four acres apiece, it is advisable to have four stews, each two rods wide, and three long. The stews are usually in gardens, or near the liouse, to be more handy and better looked to. The method of making them, is to carry the bottom in a continual decline from one end, with a mouth to favour the drawing them with a net.

It is proper to cast in bavins in some places not for from the sides, in the most sundy spots, for the fishes to spawn upon, and to defend the young fry, especially the spawn of carps and tench. 


\section{$\mathcal{A R C} \mathscr{A} \mathbb{N} A$}

I I

\section{THE AR'T OF ANGLING.}

\section{TO CATCII FISHES.}

7 AKE Coculus Indicus, which is a poisonous narcotic, called also bacce piscatorice fisher's berries and pound them in a mortar, then make balls of the paste which will be produced (by adding a sufficient quantity of water) about the size of a pea, and throw them into a standingwater; the fish that taste of it will be very soon intoxicated, and will rise and lie on the surface of the water; put your landing-net under them, and take them out.

Coculus Indicus is a little berry, about as big as a bay-berry, but more of a kidney-shape, having a wrinkled outside, with a seam running lentghways from the back to the navel: it is of a bitterish taste, being the fruit of a tree described in the seventh volume of the Hortus Malabaricus, under the name of Naslatum, bearing leaves in the shape of a heart, and bunches of five-leaved white flowers, which are succeeded by their berries. They grow in Malabar in the East Indies. They are seldom used in physic, being accounted to be of a hurtful and pernicious nature, but their principal use is for catching fishes: the famous Cardan's celebrated receipt 
for this purpose runs thus: take off the berries of the Oriental Cocus, a quarter of an ounce; of cumnin and boiling water, eagch two ounces; of cheese, one ounce, and of meal three ounces; after bruizing them together, form them into small balls. Others mix the berries with old cheese, honey, and whexten meal, of which they form small balls, to be thrown to fishes. Others for this purpose mix a variety of other substances with these berries; but after all their pains there is no necessity for so troublesome an apparatus, since I have known by experience, says Ray, that a simple ball of the powder of these intoxcating berries, made up with wheaten meal and water, is equally efficacious for stupifying, and at last killing, fishes; for that fishes, as some assert, are by eating balls of this kind, only rendered vertiginous and stupid for a while, but soon return to their natural state, is not confirmed by experience; for my own experience, says Mr. Ray, quadrates with the opinion of those fishes spoken of by the learned Condronchius, who affirms that fishes are soon killed by balls of this kind. But 1 do not know whether, as they assert, they soon become putrid, and fall into pieces, unless they are speedily taken out of the water. If, says Condronchius, any should object, that, upon taking these balls, the fishes swim up and down with uncommon hasteand precipitation, by which means their intoxication, or vertigo is produced; I answer, that they do not ramble thus in consequence of their vertigo, but in consequence of the intolerible pain they feel from that unfriendly substance, just as other animals do, especially men, when they are racked with any intense pain. I readily grant that by these balls fishes are rendered vertiginous, and 
as it were intoxicated; but at the same time, I affirm, that they are soon after killed; for I am not much of an opinion that they are rendered vertiginous, and killed by the bitter and acrid, or by some hitherto unknown qualities of these berries. I will not, however, take upon me to determine, whether fishes killed in this manner may be safely eaten, but with Condronchius, I am of npinion, that no danger attends the use of them as an aliment, if they are gutted and boiled as soon as taken. That these berries are hot, and by no means cold, as all opiates certainly are, as also Matthiolus, and others maintain, notwithstanding their narcotic quality, is sufficient'y obrious from their acrid and bitter taste, as also by the other efferts produced by them, as Condronchius has evidently demonstrated. This same author is of opinion, that these berries are by no means possessed of a poisonous and cleleterious quality, and it is not by this, but by their bitterness and primary qualities, that fishes are killed; but the contrary to me seems plain, from a story related by Arnatus. $A$ certain schoolmaster asking for cubelis from an ignorant apothecary, received these berries in their stead. When the school-master had devoured three or four of them, he was seized with a nausea, hiccough, and anxiety, which symptoms together with the danger they threatened, were immediately removed by administering a vomit: the reasoning is weak, and more about words than facts, and may be equally said of opium; the absurdity of which is evident to all who know the nature and operation of hypnotics.

This description of the Oriental Cocus, I am indebted to the late ingenious Dr. Cook for, but I nust beg leave to make some observations, 
which seem to have escaped the Doctor, and the great authorities that he has quoted.

1. I know from actual experience, that there needs no other process for making these berries up, than that which $I$ have set down; as for the wheaten-meal, which Mr. Ray mentions, it is totally useless, the plain berries pounded, and made into a paste by adding water, being a sufficient preparation.

2. It not only depends upon the size of the fishes, but upon the quantity of the paste which they pick up, which makes these berries kill the fishes, or only render's them rertiginous or intoxicated; If you take them out with a landing-net, and put them into a sufficient quantity of water, those will soon recover who have only had a small share of the paste, and may be eaten when well-gutted and cleaned, with the greatest safety.

3. That these berries are of a deletcrious nature, is sufficiently obvious by what has been said befure. A porter-brewer in London, some time ago, forfeited a considerable sum for fining his liquor with these berries. It is but necessary to kiow these secrets; but I am sure no true lover of angling will ever make use of them; only by being acquainted with them, it will enable him to detect poachers, and I hope when he meets with any, that he will put in full force the laws against them, so judiciously appropriated to clear the country of such a set of rascals.

TO TAKE A PIKE AS IIE LIES BASKING IN MARCH OR AUGUST.

Take a long pole or rod, that is light and straight, and on the small end fasten a running 
loop of twisted horse-hair and silk, of a large compass; which gently draw five or six inches over the gills, and then hoist him to shore as quick as possible. If it is a small one draw it not on so far; keep very silent; you may also take him with a hand-net, by putting it under him very gently, and then taking him up as quick as you can.

\section{OINTIIENTS TO ALLURE FISHES TO BITE.}

As many of my brother anglers may wish to try the efficacy of chemicals, towards encreasing their pastime, I here present them with a few receipts, and leave them to make their trials as they please.

Take gum-ivy, and put a good deal of it into a box made of oak, and chate and rub the inside of it with this gum. When you angle plit three or four worms into it, but they must not remain there ing, for if they do it will kill them; then take them out and fish with them, putting nore in their places as you want them out of your worm bag.' Gum-ivy is tears which drop firom the body of large ivy trees, beingwounded, and is of a yellowish red colour, of a strong scent, and sharp taste; that which is sold in the shops is counterfeit, and good for nothing. Therefore, to get gum-iry about Michaelmas, or in the spring, driye sereral great nails into large ivystalks, wiggle the same till they become very loose, and let them remain, and the gum will issue thereout.

Also slit several great ivy-stalks, at the time above-mentioned, and visit them once a month, and gather the guin which flows from the round- 
ed part. This will very muchimprove the angler's success. Probatum est.

Take assafotida, three drachms, camphor, one ditto, Venice turpentine, one ditto, pound altogether in a mortar, with some drops of the chemical oil of lavender, or spike. When you angle, anoint eight inches of your line with it, next your hook, and it is excellent for trout in muddy water, and for gudgeons in clear. Probatum est.

Assafœtida grows in Media, Lybia, and Syria; it is a gummy juice of Laser, Laserpitium, or Sylphion, gathered from the root or stalk when cut open; chuse that which is pure, fine, and clanmy, and smelling almost like garlic. It will keep many years, but is often adulterated by mixing meal, bran, and the gum Segapenum together.

Canphor is a resinous gum, partly flowing of its own accord, but chietly by incision, from a tall tree growing in India: the Bornean Camphor is best. Chuse that which is white and clear like chrystal, strong-scented, will easily crumble between the fingers, and being set on fire is difficult to be extinguished. There is a fictious sort, which being put into a hot loaf will parch, but the true willmelt: it will keep many years in flaxseed if it is not exposed to the air, otherwise it will evaporate and consume to nothing.

Mr. Wilton, in his Complete Angler, says, that if you dissolve gum-ivy in oi! of spike, anoint your bait for a pike with it, that he will take it the sooner.

I shat! now grive the reader the ne plus ultra of all these kind of ointments, composed by Mons. Charres, apothecary-royal to Louis the L'ourteenth. 'I ile cat's fat, heron's fat, and the best assafce- 
tida, of each two drachms, mummy, finely powdered, ditto, cummin seed, finely poivdered, two scruples, and camphor, galbanum, and Venice turpentine, of each one drachm, and civet two grains. Make them, seumdum artem, into a thinnish ointment, with the chemical oils of lavender, aniseed, and camomile, and keep it in a narrow-mouthed, and well-glazed gallipot, covered with a b adder and leather, and it will keep two years. When you want to use it, put some into a small taper pewter box, and ancint your bait with it, and about eight or nine inches of the line, and when it is washed off, repeat the unction. Probatum est.

"All arts and shapes, the wily angler tries,

"To cloak his fraud, and tempt the finny prize:

" Their sight, their smell, he carefully explores,

"And blends the druggist's and the chemist's stores;

" Devising still, with fancy ever new,

"Pastes, oils, and unguents, of each scent and hue."

\section{HOW TO MAKE FISH HOOKS.}

In order to make a good hook, there are requisite a hammer, a knife, a pair of pincers, an iron semi-cleam, a file, a werest, a bender, tongs, both long and short, an anvil, and steel needles of different sizes. Heat a needle of the size you want, in a charcoal fire, and raise the beard with your knife, then let it cool. Sharpen the point, either with a file or on a grindstone, then put it into the fire again, and bend it into what shape you please; make the upper part of the shank four square, and file the edges smooth, then put it into the fire a third time, and heat it gently: take it out sudcienly and plunge it in to water, and your operation is finished. 
A GLUE FOR ANGLING-RODS, \&C.

Use not a șmall hook for great baits, nor a large one for small ones:- Barbels and chubs must have linge ones, but perches, tenches, breams, and eels, much sinaller. Frouts in clear waters, grryglings, salmon-smelts, roach and dace, rufis and gudgeons, must have small hooks: and, though many angle for trouts with large hooks in thick waters, yet small ones are the best. Experience will point out the inconvenience of large hooks. The noble salmon alone must have a large one.

\section{A GEUE FOR ANGLING-RODS.}

Pour some water on some quick-lime, until the ebullition cases, then pour the water from it, and boil your glue very gently with this water and it will make a very good glue.

A RECEIPT TIIT RENDERS LEATHER MORE CAPABLE TO KERP OUT WET.

As dry feet are very necessary to health, I have copied an excellent receipt for the angler's use, that will prevent his bonts or shoes letting in water. 'Take a pint of linseed-oil, with half a pound of mutton suet, six or eight ounces of bees-ivax, and halipenny worth of rosin; boil all these in a pipkin iogether, and then let it cool till it be lukewarm; take a little hair brush, and lay it on your boots; but it is much better to be laid on the leather before the boots are made, and brushed with it once over when they are; as for your old boots or shoes, you must brush them with it when they aredry. As I am now acting the part of physician, let me advise you, whenever you are out in the heat of summer, fishing, and arc thirsty, never to drink water, as the cousequences arising from suich an indescre- 
tion may prove fatal; but either take a little brandy or rum out with you, in a wicker bottle, or wait till you come to some house where you can have a little; the effects it has of quenching the thirst, and cooling the body, are instantaneous.

The angler being now furnished with every requisite for the art of ground-angling, his strictly adhering to the theory laid down, in his practice, is the only thing he has to do, and he may depend on his endeavours being crowned with success. The sccond part of this little essay will treat of artificzal fly fishing, under every head that can prove of utility to the angler; which certainly bears the bell in that delighiful recreation, that adds strength and vigour to the body, keeps the mind in a perfect state of serenity and tranquillity, and alleviates the cares and troubles atteridant on mortality.

In short, how delightful is every species of this diversion, in such a paradise as the Poet describes:

Behind, where alders from the weather screen, Before, the lawn presents its lengthen'd scene: Close on that side trills soft the emptying brook, While this fresh woods and sloping hills o'erlook:

Thick over head the rose and woodline meet, Uniting shade to shade, and sweet to sweet;

'I'he pea and blooming bean their odours yield, And new-mown hay perfumes the fragrant ficld. To hear the nightingale delights the ineards, And grasshoppers chirp shrill amid the reeds; While from the pinfold, there, the bleating sheep Cheer the still twilight, and divert from sleep; The gale's perfume, the echo's mimic sound, The night-hird's song, and lowing kine around; In hollow ba:kss the hum of must'ring bees, And zephyrs whisp'ring soft amid the trees. 


\section{PART II.}

\section{TIIE}

\section{COMPLETE $\mathbb{F L} Y-\mathbb{F I S H E R}$ :}

OR

EVERY MAN HIS OWN FLY-MAKER.

With pliant rod athwart the pebbled brook,

Lct me with judgment cast the feathered hook,

Silent along the mazy margin stray,

And with a fur-wrought fly delude the prey.

To frame the little animal, $\mu$ ruide

All the gay hues that wait on female pride.

Let Nature guide thec: sometimes golden wire

The shining bellies of the fly require;

The pcacock's plunes thy tackle must not fail,

Nor the dear purchase of the sable's tail.

Fach gaudy bird some tend $\mathrm{r}$ tribute brings,

And lends the growing insect proper wings:

Silks of all colours must their aid impart,

And every fur promote the fisher's art. 


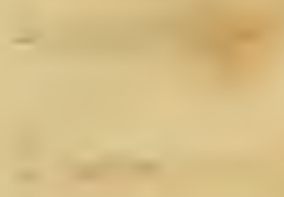

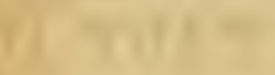

$-5=$

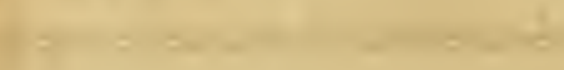

$x^{2}$

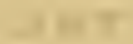

(1)

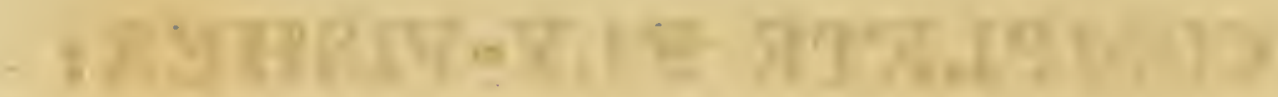

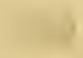

।

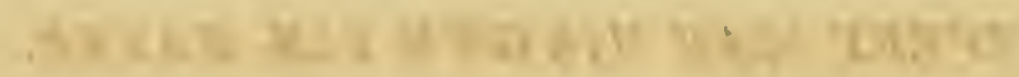

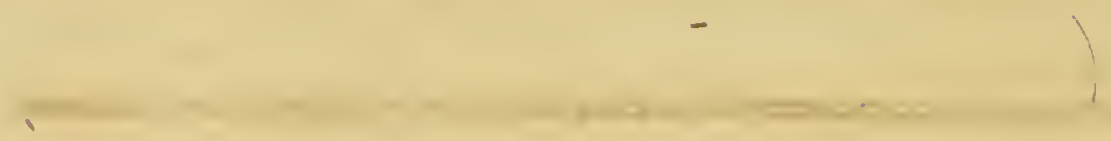

+1 1

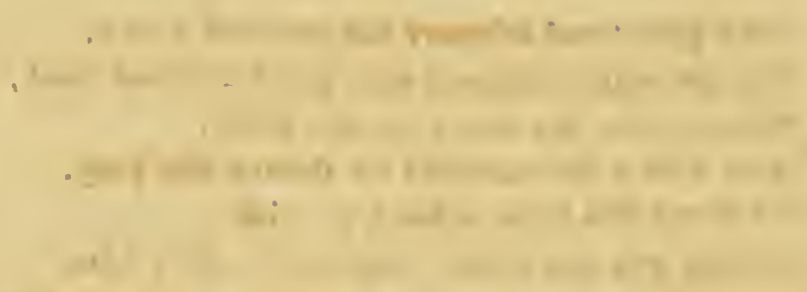

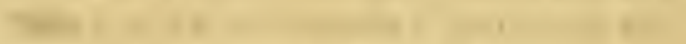
(20)

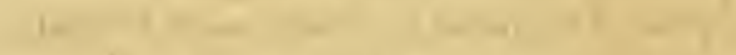

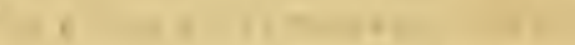

$$
\begin{aligned}
& \text { 1. }
\end{aligned}
$$

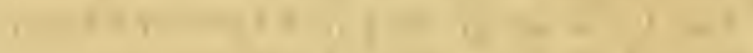

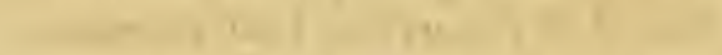

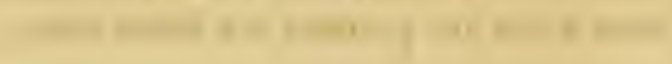




\title{
COMPLETE FLY-FISHER,
}

\author{
sic. s;c.
}

\section{CHAP. I.}

Observations concerning Artificial Fly-Angling, with proper Directions for the Angler's Rods, Lines, \&ic.

THE art of artificial fly-fishing certainly has

a the pre-cminence over the other various methods that are used to take fishes in the art of angling. It requires a great deal of ingenuity and attention, and the variety, which attends it, makes at nnce both pleasant and agreeable. The angler is not confincd to any particular part of the water in fly-fishing, but roves from one place to another, trying his fortune, by throwing his flies into the different eddies, and the most likely places he meets with, to make a captive of the speckled trout; enjoying at the same time the harmonious warblings of the numerous songsters of the groves; beholding the diversity of the prospects spread around him, and gaining that health and serenity of mind, not to be purchased by all the riches in the universe. The in:itasions of nature, in regard to the flies necessary for use; suiting the different colours so exactly 
as to resemble the natural fy; and observing the greatest nicety in regard to its symmetry; contribute to make it still more delightful. Whenever he makes a fly, let him have the natural one always before him, which will enable him to be a competent judge of the materials most necessary to dub it with; a list of which, and of the best way to make the Palmer and May-fly, (which are the ground of artificial fly-angling, I shall give him by and by; for if he is not able to makehis own flies, he never will be a good fly-fisher, nor experience that pleasure, which he will receive by taking fishes with one of his own making. He must never think a fly ill made, because it will not kill fishes as well in any other river as that he particularly angles in; because the same flies differ very much both in colour and size in different counties; besides which, fiies that will be taken on their peculiar water one year in April, will not perhaps be taken in the next till the middle of May, the whole depending on the warm th or coldness of the season. Mr. Taylor in his treatise, where he describes the superiority of fly-fishing, to the other branches of angling, with great hmmour observes, that the angler is surprised, at the manner in which the fish take theflies; and by seeing their surprize, when they find they are hooked, by rising at the flies!!! I shall now proceed to give the angler a description of the rods and lines, best calculated for artificial.fly-fishing; but before I do, shall make this one observation: that theory, without practice, can never make a man a proficient. 


\section{RODS AND LIVES PROPER FOR ARTIFICIAL FLY-FISHING, \&C.}

As for your arfificial fly-rod, the directions given in the first part of this treatiseare sufficient, only be careful that the materials which it is composed of are well seasoned, and fice from knots, and that the whole is exactly perfect in regard to symmetry.

The length of the fly-rod is generally from about fourteen to seventeen feet long; which is long enough for any oice who understands flyfishing to throw twelve yards of line, with one hand, and seventeen with both.

To make a fly rod, that will be exceedingly neat and pleasint in hand, you must observe the following method.

Procure a nice breat th of ash plank, free from knots, perfectly sound, and about seven feet long; let it be tumed in the lath so as to run taper from the but end, which should be so thick and no more than you can with case grasp in your hand; then have it ferrelled, or bind it to a piece of hazd seven feet long, and in exact taper proportion to the ash. As you may not be able to get a piece of hazel so long, that will run perfectly taper, it may consist of two or three picees; then and to the hazel a nice piece of yew (in the simme proportion to the hazel as that is to the ash) two fect long, made round, taper and smooth, and to that, piece a bit of small, round, and taper whate-bone, six inches long; then the rod will be completed; and if just symmetry is observed through the whole, it will be a most excellent one.

Sume use deal for making the bottom of the K 2 
rod, because they say it is more light; but.I in answer to that aver, that it is not half so strong and lasting, and that the ash, on account of its sirength, may be turned in the lath, or planed down to be every jot as light as the deal, and that the angler, when he has hooked a good fish, need never tear its snapping short, as deal will, because it is the nature of the wood to bend almost double, and will always, if well seasoned, return to its former straitness. Let your rod, thus made, be ringed for the line to pass through, with small bratss rings, about a font distant from each other, and at the but end let there be a spike made to screw in, which you will find very convenient; and you may, if you like to alter the colour of your joint (though it does not signify so much in ash as in deal, whose whiteness would scare the fish) first warm it before the fire, and then dip a feather in ciquafortis, put it on the ash, and then chafe it in with your hand, and it will inake it a cinnamon, or rather a puce, or flea solour.

Yone fly line should be about thirty yards long, and wound on a small brass muliplying winch, which is to be placed on the but of your rod; then you must rm the line through the rings befort-mentioned, and you may always command the length without the trouble of changing the line, and shorten it when you come to places encumbered with wood. The general length that you should have off yourreel must be about four yards longer than your rod, nay, sometimes the line must be twice the length of the rod; for to fish fine and far off is the standing rule for trout frshing. But it will be a long time before you are able to throw a dib line with nicety at the genera! length, yet as you can 
alway lengthen or shorten it by means of the winch, you may, if you are expert, and are a true lover of angling; after some trials, accomplish it. Never incumber yourelf with too much line at first, but increase the length of it as you find you make improvement; and is it is ten to one, that you loose a fly every time you cast your line, until you are arrived at some degree of perfection in doing it, it will not be amiss to practice sometimes without one. But let me return to the subject: your line should run timper from the top of the rod down to the fly, that is, if the first link is composed of thirty-five hairs, the next must be of thirty-four; so learing out one hair in each link, till the whole is completed; then comes the silk worm-gut, on which you should whip all your hooks.

But the best lines for artificial fly angling are those that are wove, and are all one piece, and are to be bought at any of the shops in London, where fishing-tackle is sold, and run taper like the lash of a coach whip, and may be had at any length; as from thirty to forty yards, \&c.

These are the only lines that can be used on a winch; because they have no knots to prevent them running gibly through the rings of the rod.

By the line being made taper, you will be able to throw it into any place youlike with a greater exactness, and it will fall much lighter on the water, which will very much increase your sport,

The reader now being informed of the rod and lines best calculated for arlificial fy-fishing, I shall in the next chapter give him a list of the materials he must be in possession of betore be 
attempts to make flies, and afterwards give him the best instructions for making them.

The directions which I have given the angler respecting his rods and lines, are the best I believe now extant; however, I would advise every young angler to make a purchase of his first tackle at the London shops; he will there get rods and other tackle in the highest perfection, and neatness, which he should always be careful to keep in good order; and to never regard what bunglers and slovens tell him; but believe neatness in his tackle, and a nice and curious hand in all his work (particularly in fy-making) to be absolutely necessary.

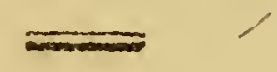

CHAP. II.

A Lisu of thie Materials necessary for an Angiter to have, and the best method to make the Palmer and May-fiy.

\section{HOG'S DOWN,}

COMBED from the roots of the bristles of black, red, whitish, and sundy-coloured hogs: the white down you may have dyed to any colour you like. It is excellent dubbing, because it will stand the water and shines well. To be a competent judge of the real colour of any dubbing, yon must hold it between the sun and your eycs. This is a standing rule when you initate at fly. 


\section{CAMEL'S ITAIR,}

Of a dark and light colour, and one in the merlium of both.

\section{BADGĖR'S HATR,}

The brown soft fur which is on the skin, and the blackest.

$$
\text { BEAR'S HAIR, }
$$

Grey, dun, light and dark coloured, bright brown, and shining brown.

$$
\text { SPANIEL'S HAIR, }
$$

From the different parts of a spaniel, especially from behind the ear, brown, dark brown, light brcron, and black.

$$
\text { SHEEP'S WOOL, }
$$

Of all colours, both natural and artificial; you may have it dyed to any colour.

$$
\text { SEAL'S FUR, }
$$

To be had at the trunk-makers; get it dyed from the lightest to the darkest brown, and you will find it much better dubbing than cow os calves' hair.

\section{MIOHAIRS}

Of all colours, black, blue, purple, whitite, violet, yellow, and tawney, philomot, from feulle morte, 
a deaf leaf; and Isube!la, which is a whitish yellow, or soiled buffi colour.

\section{COW'S HAIR,}

The softest you can get from a black, brinded, and red cors; and of these colours, have brown, dark brown, light brown, and black.

\section{COLT'S OR CALVE'S HAIR.}

These afford very good dubbing, and a variety, especially those hides that have been tewed, or dressed in a skinner's lime-pit; but, as I said before, seal's fur dyed is much better than either cow's or either of the hairs of these two; because it is not so harsh, and does not require so much trouble to work on the hook; and observe further, that this fur is for small flies, and hog's down for large ones.

\section{CAMTETS,}

Both hair and worsted of all colours, blue, yellow, dun, brown, dark brown, light brown, red violet, purple, black, hore-flesh, pink, and orange.

\section{FURS,}

Off the squivrel, especially his tail; a hare, the part off the neck which is a whithered fern colour; foxcub from the tail where it is downy and of an ash colour; an old fox, and old otter, ottercub, futimart, or filmert: a mole, a black cut's tail; a house-mouse, and water-rat; a marten, particularly from off the gills, or spots under the jarvs, 
which is of a fane yeliow. These are all to be had at the fumiers.

II ACKLES.

These are the feathers that hang from the head of a cock, down his neck, and likwise near his tail, they are particularly used in making the palmer-fly; get the following colours of them, viz. red, dun, yellowish, white, orange, and black; let not the fibres of them be above half an inch long. Whenever you meet with a cock, whose hackle is of a strong brown red, buy him, and make the most of the hackles. Note, the feathers of a bantam or cock-chick, are good for nothing.

\section{FEATITERS.}

To make the wings of artificial flies, \& $\mathrm{c}$. it is necessary to be provided with all kinds of feathers; procure therefore those from the back, and other parts of the wild mallard or drake; of a partridge, particularly the red ones in the tail; those of a cock-pheasunt's breast and tail; also the wings of a stare or starling, jay, land-rail, black bird, throsle, fieldfare, water-coot, and a brown hen; likewise the top, or cop, of a perit, plorer, or lap-reing, peacock's herl, green, copper-ioloured, and white, also black ostrich's herl, and feathers from the neck and wings of a heron. Observe, that in many instances hereafter that you will meet with, where the mallard's feather is set down for the wings of an artificial fly, that the starling will be preterable, because it is of a finer grain, and will not imbibe the water so mench. 
There is very good dubbing to be got from blankets, also from an old Turkey caryet; untwist the yarn, and pick out the wool, then separate the colours, wrap them up in different papers, and lay them by.

\section{SILRS, \&ic.}

In this drawer, which is the last, keep small, though strong silk of atl cclours, wrapt on little reels; also raze silk, gold and silver fiarled tive, or taist; hooks in small chip boxes, with the number of the size of each niarked on the outside: wax of ail colours, and needles; a shrup penknife, and a small sharp pair of scissars, made quite angular, with large bows for the fingers.

N. B. When you make the palmer-fly suit the colour of the silk to the hackle you ditb with; a dun hackle requires yellow silk; a black haikle, sky-bhie silk; a brown, or red hackle, red silk: when you make flies that are not palmers, dub with silk that resembles the colour most predomineat in the fity and in making your flies, remember to mis bear's hair and hog's down, with your other dubbing, because they repel the water; make your flies always in hot sun-shiny weather, for rour waxed silk will then draw kindly; and when you take the dubbing to imitate a tiy, always wet it, and then you will be perfect in yourimitation; for althongh the dubbing when dry may suit, yet when it is wet it may be quite another colour. Murten's fur is the best yellow you can use. 
Fir:t lay al! the materials by the side of you, viz. hall a yard of fine round even silk roorm gut: hall a yard of red silk well waxed with wax of the same colour, a hook, the size No. 0 : a ntedle: some strands of an ostrick's feather, and a fine red halile: then take the hook, and hold it by the bend, between the fore-finger and thumb of your left hand, with the shank towards your right hand, and with the point and beard of your hook not under your fingers, but nearly parellel with the tops of thom: aflcrwards take the silk, and hold it likewisc about the middle of it, with your hook, one part laying along the inside of it to your left hand, the other to the right; then take that part of the silk which lies towards your right hand, between the fore finger and thamb of that hand, aidd holding that part towards your left, tight, along the inside of the hook, whip that to the risht, three or four limes round the shank of the book towards the right hand; after which take the silk reorm gut, aud lay either of its ends alongthe inside of the shank of the hook, till it comes near the bend of it: then hold the hool, silli, and gut, tight between the fore finger and thumb of your left hand, and afterwards grive that par". of the silli to your right hand, three or for whips more orer both hook and gut till it comes near the end of the shank, and make a loop and fasten it light: then whip it neatly again over both silk, gut, and hook, till it comes near the bend of the hook: after which make another loop, and fasten it again : then if the gut should reach further than the bend of the hook, cut it off, and your hook will be 
whipped on, and the parts of the silk hang from the bend of it.

Having proceeded so far, wax the longest end of the silk again, and take three or four strands of an ostrich's feather, and holding them and the hook, as in the first position, the feathers to the left hand, and the roots of them in the bend of the hook with the silk that you waxed last, whip them three or four times round, make a loop, and fasten them tight; then turning the strands to the right hand, and twisting them and the silk together, with the fore finger and thumb of your righthand, wind them round the shank of the first hook tili you come to the place where you fastened, then make a loop, and fasten them again; if the strands should not be long enough to wind as far as is necessaiy round the shank, when the silk gets bare you must twist others on it. Haring performed this, take your scissars and cut the body of the painer into an oval form, that is, small at the bend and the end of the shank, but full in the centre; do not cut too much of the dubbing off. Now both the ends of the silk are separated, one at the bend, another at the end of the shank, wax them both again; then take the hackic, hold the small end of it between the fore finger and thumb of your left hand, and stroke the fibres of it with those of your right the contrary way from which they are formed; hold your hook as in the first position, and place the point of the hackle in its bend, with that side which grows nearest the cock upwards, and then whip it tight to the hook; but in fastening it tie as few fibres in as you can possibly avoid: the hackle being fast, take it by the great end, and keeping the side nearest the cock to the left hand, begin with your righthand to wind it 
up the shank upon the dubbing, stopping every second turn, and holding what you have wound tight with your left fingers, whilst with the needle you pick out the îbres you will unavoidably take in; procecd in this manner till you come to the place where you first fastened, and where an end of the silk is: then clip off those fibres of the hackle which you hcld between your finger and thumb, close to the sten, and hoid the siem close to the hook, afterwards take the silk in your right hand, and whip the stem very fast to the look: then make up a loop, and fasten it tight: take your pen-knife and if - that part of the stem next the shank of the hook is as long as the part of the hook which is bare, pare it fine, wax your silk, and bind it neatly on the remaining bare part of the hook: then fasten the silk tight, and spread some shoemakcr's wax very lightly on your last binding; after that clip off the ends of the remaining silk, both at the shank and the bend of the hook, and all fibres that start or stand ill-conditioned, and the whole is completed.

This is called the palmer Hy or plain hackle and may, instead of the nstrich's father above-mentioned, be dubbed with black spaniels fur, and is a rery excellent killer. There are three more palmers, which are all to be marle in the same manner as I have laid down, only with different atricles, which are follows:

\section{GIEAT PALMER, OR HACKLE.}

Dubberl the same as the plain hackle with the strinds of an ostriclis feather, or a black spanicl's fur, and warped with red peacork's hackle, untrimmed, that is, leaving the whole length of the hackle staring out (for sometimes the fibres of the 
hackle are to be shorteried all over, sometimes Sarbed only a little, and sometimes close underneath) leaving the whole length of fibres on the top, or back of the fly, which makes it swin better, and on a whirling round water, kills great fish. Your hook for this palmer, No. 5.

\section{GOLDEN PALMER, OR IIAKLE.}

The same dubbins, ribbed with gold twist and a red kackle over all.

\section{SILVER HACKLL.}

Made with black body also, silver twist over that, and a red hackle over all.

The variation that is to be observed in making the gold and silver palmers is this, that when you whip the end of the hackle to the bend of the hook, you must also do the same to the gold or silver twist, and first wind either of them on the dubbing, observing that they lie flat on it, and then fasten off; afterwards proceed with the hackle as directed: or you may wind the hackle on the dubbing first, and rib the body with either of the twists afterwards.

These are the standard hackles in fly-fishing, and are taken any month in the year, from nine to cleven in the morning, and from one to three in the evening, and upon any water; though you must have different sizes of them, and dubbed with different colours, that yon may always be able to suit either a clear or dark water, or a bright and cloudy atmosphere; observing, that small. light-colvured flies are for clear waters and slies, and the largest for dark and cloudy ones.

These palmers (as I said before) being taken 
every month in the yeal, when I come to treat of the Hies proper: for each inonth, I shall not take any notice again of the four which I have set down, for that would be totally unnecessary; but the others that deviate in their size and dubbing fiom the general rule, will be fully explessed.

the angler should always try the palmers first, when he fishes in a river that he is unaccustomed. to; and even in that which he constantly uses, without he knows what $f y$ is on the water, and: they should never be changed till he does; the on $y$ way to come to the true knowlergge of which, he must observe an old established rule laid down for that purpose; and as it is poetically described by. Mr. Gay, I shall give it him. in that dress.

Mark well the various seasons of the year, How the succeeding insect race appear; In this revolving moon one colour reigns, Which in the next the fickle trout disdains.

Oft have I seen a skilful angler try

The various colours of the trearh'rous fly;

When he with fruitless pain hath skim'd ihe brook; And the coy fish rejects the skipping hook, He shakes the boughs, that on the margin grow, Which r'er the stream a weaving forest throw; When if an insect fall (his certain guide) He gently takes him from the whirling tide: Examines well his form with curious eyes, Ilis gaudy vest, his wings, his horns, and size; Then round his hook the chusen fiur he winds, And on the back a speckled feather binds; So just the colours shine through ev'ry part, That Nature seems to live arain in art.

THE BEST METHOD TO MAKE AN ARTIFICIAL FLY, NOT A PALMER.

First hold your hook tast betwixt the fore finger and thumb of your left hand, with the ᄂ 2 
back of the shank upwards, and the point towards your right hand; then take a strong small silk, of the colour most predominant in the fly you intend to make, wax it well with wax of the same colour and draw it between your finger and thumb to the head of the shank, then whip. it twice or thrice about the bare book, which prevents its slipping, and the shank of the hook firm cutting the gut: which being done take your gut and draw it likewise between your finger and thumb, holding the hook so fast as only to suffer it to pass by, till the end of the gut is near the middle of the shank of the hook, on the inside of it; ther whip the sils twice or thrice about both gut and hook, as hard as the strength of the silk will permit; after that take the wings, which before you began to make your fiy you had stripped oft the stem for its wings, and proportional to it, and which lie with your: other materials by you, (as they always should before you begin) and place that side downwards which grew uppermost before, upon the back of the hook, leaving so much only, to serve for: the length of the wings of the point of the plume, laying it reversed from the end of the shank upwards, then whip your silk twice or thrice about the root-end of the feather, gut, and hook; which being done, clip off the root-end of the feather close by the arming, and then whip the silk fast and firm about the hook and gut till you come to the bend of it; and then, if the gut goes beyond the bend of the hook, cut it off, and make all fast: take then the dubbing which is to make the body of your fly, as much as you think will do, and holding it lightly with your hook, between the finger and thuinb of your left hand, take the silk with your right hand, 
and twisting it between the finger and thumb of that hand, the dubbing will spin itself about the silk, which, when it has done, whip it about the armed hook, till you come to the setting on of the wings: afterwards take the feather for the wings, divide it into two equal parts, and turn them back lowalus the bend of the hook, the one on the one side, the other on the other side of the shank, holding them fast in that posture, between the fore finger and thumb of your left band; which being done, warp then so down as to stamb, and slope towards the bend of the hook; and having warped up to the end of the shank, hold the fly fast between the finger and thumb of your left hand, and then take the silk between those of your right, and where the warping ends, and pinch and nip it with your thumb-nat aganst your hinger, and strip away the remainder of your dubbing from the silk, which wax again, and then with the silk which is newly waxed and bare, whip it once or twice abont, make the wings stand properly, then fasten and cut it off: after which, with the point of a ncedle, raise up the dubbing gently from the warp, twitch off the supertiuous hairs of your chbbing, leave the wings of an equal length, (or your fly-will never swin true) and the whole is completed.

In this manner you are to make the May-fly or green-dratie, and all other flies that are not palmers; the inaterials to make the green-drake are the following: Your hook must be No.5, and you must have the white-grey feather of a mallard for the wings, dyed yelluw; the dubbing camel's hair, bright bear's hair, yellow camlet, and the soft down that is combed from the bristhes of. a hog; well mixed together; the body. 
must be long, and ribbed about with green silk, or rather yellow, waxed with green was, and three long hairs for his tail, from those off a sable's.

Or, the May-fly may be dubbed after this method. The body of seal's fur, or yellow moliair, a little fox-cuib down, and hog's down, or light brown from a turkey carpet, mixed together, warp with green and yellow, pale yellow, or red cock's hackle under the wings, which are to be the same as in the other method of dubbing it.

As I sball not mention the green-drake when I come to describe other flies taken in the month of May, I will here give you every particular concerning it. He comes. on the water the twenticth of that month, and is taken all day long, but best from two to four in the evening, and lills most fish from the end of May to the minth of June.

\section{HOW TO DYETHF MALLARDS FEATRER}

Y 3 illow.

Take the root of a Babary tree, and shave it, and put to it roody riss, with as much alum as a walnut, and boil your feathers. in it with rain. water, and they will be of a fine ycllow; or ger al litte zeld and rocou, and boil your feathers with. them, and it will answer the same purpose. 


\section{CHAP. III.}

The Names, and the best Marmer of dubling the different Artificial Flies, which are generaliy linozen, and will liill fishes on any W'ater. from the beginning of March to the end of September.

SHALL begin $A y$-fishing with the month of M. March, that being soon enough to throw a fly on the water; nay, in some ycars is too soon, owing to the backwardness of the season. The inclemency of the weather, before that time, renders the attempt not only unpleasant, but fruitless, to endeavour to take fishes with the fly; and. the risk a man runs of impairing his health, standing by the water-side before the weather is mild and temperate, forms an objection more strongly against it. Let the angler be ever so fond of fly-fishing he will certainly have enough, perhaps a satiety between the months of March and september; besides the mind of man is fond of variety, and the ainusements of the ficld very pleasant and conducive to health; for I myself an entirely of 'Terence's opinion, that

Ad prime in vila esse utile, ut nequid nimis.

\section{MAPCH.}

TIIE PALIIERS.

1. The Dark Brown.

2. The Green Whirling Durn.

3. 'The Early Bright Brown.

4. The Thorn, or Hawthorn 'Tree-Fly. 5. The Blue Dun.

6. The Little Black Gnat: 7. The late Bright Broun. 
1. Dubbed with the brown hair off the shank of a brinded cow, and the grey feather of a drake for wings.

2. Dubbed with the fur from the bottom of a squirrel's tail, and the wings of the grey feather of a drate. Or, dubbed with squirel's fur, mixed withabout a sixth part of fine hog's down, she wings of a pale onange colour, taken from the quill feather of: aruddy hen, the head to be fastened with ash-coloured silk, and a red unbarbed cock's hackle may be warped under the wings, and a turn or two lower towards his tail.

This is a very filling fly, and is tuken best late in. the erening of a blastering warm day.

3. Dubbed with the brown hair off a spaniel, taken from behind the ear, or with that of a red cow's fiank; the wings, the grey feather off a wild drake.

4. Dubbed with seal's fur, dyed a perfectblack, mixed with a little Isabella-coloured mohair, the body made small; and the vings of a bright mallard's featler. A killing fly.

5. Dubbed with the down combed from the neck of a black greyhound, or the roots of a fox-cub's tail, mixed with a little blue violet worsted, upon a hook, the size No.9. the wings off the pale part of a starling's feather.

This fly is a killing fly, and is taken from eight to eleven, and from one to three.

6. Dubbed with black mohair, upon a hook. the size No.9. and the wing's the lightest part off. a starling's feather.

7. Dubbed with the hair off a cow, or calf's hide, which has been dressed in a.skinner's limepit; if you hold it between your eyes and the sun, it will appear of a bright gold, or amber cclour; the wings off a feather of a brown hen.. 


\section{APRIL.}

I'AIMERS.

1. The Darle Brown,

2. The Violct I'ly.

3. The Little Whirling Dun.
4. The Y cllow Dun.

5. T'he Horse-glesh Fly.

6. The Sinall Bright

Brown.

1. Dubhed on a small hook, No. 8 or 9 , with brown seal's fur, or with brown spanicl's fur, that looks ruddy, by being exposed to the weather, mixed with a little violet camlet; walp with yellow silk, and the wings off a grey feather of a mallard. Kills best from eight to eleven.

2. Dubbed with dark violet stuff, and a little dun bear's hair mixed with it ; the wings off the grey feather of a mallard.

Kills very acell from the sixth to the tenth of this month.

3. Dubbed with fox-cub down, ash-coloured at the roots, next the skin; ribbed about with yellow silk, the wings of a pale grey featlier of a mallard. Or, dubbed with the same down, and a little rudidy brown mixed, warped with grey, or ruddy silk, a red hackle, under the vings, which must be made fiom the feather of a landrail, or ruddy brown chicken, which is betier.

This fly comes on the water the tacelfith of this month, and is taken in the middle of the ding, and all the month through, and in blusiering weather to the end of fune.

4. Dubbed with camel's hair, and marten's yellow fur, mixed togetiser; or with a smail quantity of pale yellow cruel, mixed will ios-o cub down from the tail, warpped with yellow 
silk; and the wings oif a pale starling's feather.

Thisfly is talien from eight to eleven, and from tawe to form:

5. Dubbed with blac mohair, and with pink. and red colour tommy mixcd, a brown head and. light-colomed wings.

'l'kis fly is taken cill the month tao hours before sun-set tili twilight.

6. Dubbed with spaniel's fur, the wings the lightest part off a stare's feather.

l'aken very well in a bright day cind clear wate:.

\section{MAY.}

\section{PALMERS.}

\section{The May-Fly.}

1. The Dun Cut.

2. The Stone Fly.

3. The Black MIay-Ily.

4. The Littl: Y elluw Mayfy.

1. Dubbed with bear's hair, of a brownish colour, with a little blue and yellow mixed with; it; the wings of a brown hen; and two horns at the head from the hairs of a squirel's tail. Or, dubbed with bear's cub fur, a little yellow and green cruel mixed with it, warped with yellow, or green; wings of a land-rail.

A great killer in the evening of a showry day.

2. Dubbed with clun bear's hair, mixed with a hittle brown and yellow camlet, so placed that the fly may be more yellow on che-belly, and towards the tail, than any where else; place two or: three nairs of a black cat's beard on the top of the hook, in the arming it, in such a manner that 
they may he tumed up when you warp on the dabbing and stand allinost upright, and start one fiom the other, rib the body with yellow silk, and make the wings very langes oft the dark grey feathers of a mallard. The hook No. 3.

This is a very grent litler, and comes on the waler about the middle of April, and comlinues till thie end of June; it is generully used in swilt streams, lut if there is : good achal strring it will be triten in ihc deeps; it is laken but indifjerenthy in the middle of the day, but cacellently late and early.

3. Dubbed with the strands off a black ostrich's feather, ribbed with silver twist, and a blitck cock's backle orer all.

A good killer, but not to be compared with the Green Drake or Stone-fly.

4. Dubbed with yellow camlet, or yellow marten's fur, the wings off a mallard's feather dyed yellow. This ty is to be made very smatl, but exactly in the shape of the grecu dratie.

5. Dubbed with whitish hog's down, mixed with black spaniel's fur, ribbed with black silk; b]ack cat's beard for the whisks of the tail, and the wings off the black grey feather of a mallard. Or, dubbed with white ostrich's feather; the end of the body, towards the tail, off peacock's herl, warping of ash-colour, with silver twist, and black hackle, and the wings a dark grey feather of a mallard.

A very lialling. fly, especially tonards an evening, when the fishes ore glutted wilh ine green druke.

6. Dubbed with dark brown shining camlet, ribbed over with very small green silk, and the wings oft the double grey feather of a mallard.

It roill kill smallfishes, and rontinues till the end of June. 
7. Dubbed with light brown and yellow mixed or dinty lemon-culoured mohair, with the same coloured hackle under the wings, which may be either mate of the feather off a land-rail, or a dark grey leather of a mallard.

The size of the hook, No. 7 .

This fly is used in cold windy days.

\section{JUNE.}

\section{THIE PALHERS.}

1. The Aint-Fly.

2. Purple Gold Palner

3. The Liıtle Black Gnat. 6 . The Small Red Spinner.

1. Dubbed with brown and red camlet mixed; the wings the pale part of a staling's feather.

๑. Dubbed witl puple mohair, ribbed with gold twist, and rea cock's hackle over all.

3. Dubbed with the black strands off an ostrich's feather, upon a houk the size No.9, and the wings of the lightest part of a starling's feather.

A great killer after a shower of rain, especially in an evening.

4. Dubbed with light brown seals hair, wayped with ash-coloured silk, and a red hackle over all.

5. Dubbed with seal's fur dyed red, and brown bear's hat mixed together, but there must be bear's hair sufficient to make the body appear of a dullish red, ribbed with gold trist, the wings off a stare's feather; and red cock's hackle orer the dubbing. The hook, No.7. 
This fly kills very well till the latter end of August, from six o'clock till twilight, upon a darkcoloured rater.

6. Dubbed with the yellow of a spaniel, taken from behind the ear, ribbed with gold twist, a red heckle over all, and the wings off' a starling's feather. The hook, No 8 or 9.

This fly kills exactly at the same time the other spinner does, but when the water is very clear.

\section{JULY.}

\section{THE PALMERS.}

1. The Badger Fly. 2. The Orange Fily. 3. The Wasp Fly.
4. The Black PaTmer.

5. The Black Silecr Palmer. 6. The July Dun.

1. Dubbed with the soft brown fury off a badger's stin, warped with red silk, the wings oft the dark grey feather of amaliad; the head must be red.

I'hisfly is an excellent liiller, and in some river's is taken in March and April.

2. Dubbed with orange-coloured wool; the wings off the father of a black-bird's wing. Or, dubbed with raw ormuge silk, warped with silk of the same colour, riblued with gold twist, and a black or red hackle over all.

This fly is taken in June when the MIay-fly is over, in hot gloomy weather, and till the end of this month.

3. Dubbed with brown bear's hair, or the fur off a black cat's tail; ribbed with yellow silk; nd the wings off the pale feather of a stare's in $\mathrm{g}$. 
4. Dubbed with the herl off a copper-coloured peacock's feather, with a black cock's hackle over it.

5. Dubbed the same as the Black Palmer; ribbed with silver twist and black hackle over all.

6. Dubbed with the down off a water-mouse, mixed with blueish dyed seal's fur; or, dubbed with the fur off a mole, mixed with a little marten's fur; warped with ash-coloured silk; the wings off the feather of a blue pigeon's wing. The size of the hook, No. 9.

A good kilier.

\section{ALGUST.}

THE PALMERS.

1. The Late Ant Fly.

2. The Fern Fly.

3. The White Palmer.
4. The Hcarth Fly.

5. The Pule Blue.

6. The Harry Long Legs.

1. Dubbed with the hair off a cow that is of a blackish brown; warp some red in for the tag of his tail, the wings off the feather of a brown hen.

An excellent killer.

2. Dubbed with the fur off a hare's neck of a fern colour: the wings off a darkish grey feather off a mallard's.

3. Dubbed with the white herl off a peacock's feather, and a white hackle over all.

4. Dukbed with the wool off an aged black ewe, mixed with sonı grey colt's hair; the wings off those of a starling's.

5. Dubbed with very light blue fur, mixed with a little yellow marter's fur, and a blue hackle over all, the wings of the feather of a blue pigeon. The hook, No.3. 
A tery killing. fiy from ten in the morning till three in the evening.

6. Dubbed with darkish bear's hair, mixed with a little bluc wool, and a brown hackle over all. Or chubbed with lightish bear's hair, mixed with a few hairs of light blae mohair, and a little fox-cub down, warped with light grey or pale blue silk, and a dunnish hackle over all; the head made large. 'The hook, No. 5.

Taken chiefly in a cloudy windy day.

\section{SEPTEMBER.}

\section{TIIE PALMERS.}

1. The Peacock Hackle.

2. The Canel Brown.

\section{The Late Badger. \\ 4. The Scrtember's Dun。}

1. Dubled with Peacock's ruddy herl; warped with green silk, and a red cock's hackle over all.

2. Dubbed with the hair pulled out of the lime of an old wall; warped with red silk, and the wings of the dark grey feather of a mallard.

3. Dubbed with the fur off a black badger's skin, mixed with the softest yellow down of a sanded hog, and the wings off the feather of a dark grey mallard.

4. Dubbed with the down off a mouse; warped with sad ash-coloured silk; and the wings off the dark-coloured feather of a stare's. The: look, No.?.

I have given the reader forty-seven of the best flics used in fly-fishing, and what are generally Fnown; with the best methods of dubbing them; and which, if he pays atlention to, and makes his exceptions with judgrnent, he may in time become an cxcellent fly-tisher. 
A Selection from the foregoing List of Flies, that will kill fish in ciny part of England and Wales, particularly Trout.

\section{THE PALMER.}

5. Great Dinn.

6. Dark Brown.

7. Early Bright Brown.

8. Iate ditto

9. Blach Gnat.

10. Tellow Dun.

11. Great Whirling Dun.

12. Tittle ditio.

13. Duin Cut."
14. May-Fly.

15. Grey Drake.

16. Camlet Fly.

17. Cozi-dung $F l y$.

18. Little Ant Fly.

19. Badger Fly.

20. Fern Fly.

21. Stone Fly.

N.B. There are two Salmon-fies, which are the principal ones, called the Dragon and King'sfisher, about two inches long, which may be made according to fancy; but of the most gaudy feathers there are, especially the peacock's, for they will rise at any thing gavely, and where they are plenty at Trout-fies.

There are likewise two moths which I have omitted, great killers about wilight in a serene evening; and the humble-bee, a famous chubkiller, any time of the day. They are dubbed in the following manner:

The brown-moth - the wings off the feather of a brown ow; dubbed with light mohair, with a dark grizzle cock's hackle for the legs; and a red-head.

The white-moth--dubbed with the white strands of an ostrich's feather; wings off the 
feather of a white pigeon's wing: a whitehactile for the legs, and a black head. The hooks for both, No. 2 .

The humble-hee-dubbed with black spaniel's far; a black coch's hackle over that; the tag of the tail to be of a deep orange colour: and the wings of the feather of a crow's wing. Thr hook, No. .

When artul fies the angler wou'd prepare,

'This task of all deserves his utmost cire:

Nor iere or prosecan ever teach hian well What masters unly know, and prartice tell. Yet lins at lirge i venture to shpport,

Nature best followit, best secures the sport. Of tics the kinds, their seasois, and their breed, Their shapes, their hue, with nice observanee heet: Which must the Jront atmires, and where obtain'd, Experience best will leach you, or some friend:

Fur several kinds must ev'ry month supely,

So great's his passion tur vitriety !

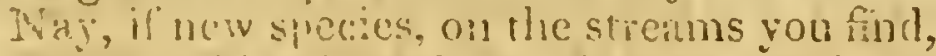
'tri-julit achuwledge fortuns amply kind. Mu-res Buovive.

\section{CHAP.IV.}

FTHE list of fies which I have given the anogler, he may depend are the standird for amilieinl Ify-fisthing; but as I an willing to give him as lauch scope as possible, (1) chible fim to becone an adept in his pleasant and

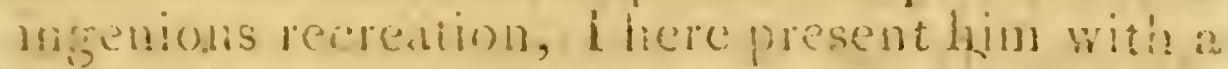
serond list, which he must matic use of at his. experience in artiticial fly-fishing increases; and I dare atfun, that it he makés a juducions application of this and the firmer list, and observes the rules laid down tor the weatier, pro. 
per for this sport, he will never go home with an. empty pannier.

\section{THE RED FLY.}

Comes on about the middle of February, and continues till the end of March : its wings are made artificially, of a dark drake's feather; the body of the red part of squirrel's fur, with. the red hackle of a cock, wrapped twice or thrice under the but of the wing; has four wings, and generally Hutters upon the surface of the water, which tempts the fishes, and makes them take it the more eager. The size of the hook, No. 6 .

\section{THE BLUE DUN FLY.}

Comes on the beginning of March, and continues till the middle of April; its wings are made of a feather out of the starling's wing, orthe blue feathers that grow under the wing of a duck widgeon; the body is made of the blue fur off a fox, or the blue part of a squarrel's fur, mixed with a little yellow mohair, and a fine. blue cock's hackle wrapped orer the body, in imiration of the legs: as it swims down the water, its wings stand upright on its back; its tail forked, and of the same color of its wings. It appears on the water about ten o'clock in the forenoon, and continues till about three in the afternoon; but the principal time of the day is from twelve till two; the flies then come down in great quantities, and are always more plentiful in dark, cold, gloomy days, than in: bright sun-shiny weather. Your morning's fishing, till the fliescome on, should be with the worm 
or minnow; the size of the hook this fiy is made on, is No 7 ; but if the roater is very loro and fine, No. 8.

\section{TIIE BROWN FLY, OR DUN DRAKIE.-}

Comes on abont the middle of March, and continues till the latter end of April; its wings are made off the feather of a pheasant's wing which is full of fine shade, and exactly rescmbles the wing of the fly; the body is made of the bright part of hare"s fin, mixed with a little of the red part of squirrel's fur, ribbed with yellow silk, and a partridge's hackle wrapt over twice or thrice under the but of the wing: as it swims down the water, its wings stand upright upon its back, its tail is forked, and the color of its wings: it comes upon the water about eleven o'clock, and continues on till two, appearing on the water in shoals, or great quantities; in dark gloomy days, at the approach of the least gleam of sun, it is amazing to see, in a moment's time, the surface of the water almost covered with ten thousands of these pretty little flying irsects, and the fishes rising and sporting at them, insomuch that you wonld think the whole river was alive; it is a pleasing sight to the angler, and affords him great diversion; in this manner they appear on the water every successive day, till the end of their duration. The blue dun, and the brown, are both on at the same time; the blues are most plentiful in cold and dark days, and the browns in warm and gloomy days; though I have often seen blues, browns, and granams, on at the same time, when they have refused the other two. sorts, and have taken the browas 
only: there camot be too much said in commendation of this Ay, bo:h for its duration, and the snort it affords the angler: The size of the hook it is made on, is No. 6.

\section{THE GRAYAM FEY, OR GREENTAIL.}

Comes on about the begining of April, if the weather is warm, being a rery tender fly, and cannot endure the cold. When they firs appear on the water, they do so in greal gluantiries, in bright mornings; you may begin to. fish with them from six o tolot in the morning till eleven; then you wilt find the browns come on, which you must use, as the fish will not touch the granams as long als the browns continue; abcint five o'clock in the evening you may use the granams again with success, the browns having then totally disappeared for that day. The granam-tly is a fou winged fly: as it swims down the water its wing lie flat on its back, it bas a small bunch of eggs, of a green colour, which gives it the name of the Grectr-tail Hy; as soon as it lights on the wates, it drops its esgs; it is of short duration, not lasting. above a ixeek, and then totally disappears for that year. The wings are made from a feathe: out of the wing of a partridge or pheasant, which is shaded like the wing of the Ay; the borly is made of the tur from a hare's face, or ear, and a grizzled hackle of a cock wrapt under the but of the wings. The hook, No. 3 .

\section{-TIIE SPIDER FIT.}

Comes on about the twentieth of April, if the weather is warm; and continues on about 
a fortnight: they are bred in beds of gratrel by the water-sice, where you may fund them in bunches engendering, to prepare for their production the next year: in cold and stormy days they hide themselves in the gravel, not being able to cudure cold. Yon may fish with it from sun-rise till sun-set; being a very killing fly, too much cannot be said in its praise. The wings are inade from a woudcock's feather, out of the but of the wing ; the body of leadcoloured silk, with a black cock's backle wrapt twice or thrice under the wings. This fiy cannot be made too fine. The hook, No.8. or 9.

\section{THE BLACK CATERPILLAR.}

Comes on about the beginning of May, and continues on about a fortuight, and is to be fished with after hot sur-shiny mornings; if winds and clouds appear, they then grow weak for want of the sun, and fall upon the waters in great quantities. The wings are made from a feather out of a jay's wing, the body of an ostrich's feather, which is preferable to the plover's, and fine black cocis's hackle wrapt over the body. It is a very licling gly in small brools. The hook, No. 7..

\section{THE LITTLE IRON-BLUE FEY.}

Comes on abont the seventh of May, and continues on till the middle of Jume. In cold stormy days they come down the waters in great quantities, but in warm days there are but few to be seen. As it swims down the water, its wings stand upright on its back; its tail is forliced, and the colour of its wings: it is a neat 
crious ily, and cannot be male too fine; it is to be fished with from abour eleven o'clock in the forenoon till three in the afternoon. When these flies are on, the fishes refuse every other sort, and take these only, every solt of fish being fond of them. The wings are made from a cormorant's feather that grows under the wing, or off the feather of a dark blue-hen, that grows on the body, under the wings ; the body is made of water-rats fur, ribbed with yellow. silk, and a sooty blue hackle of a cock, wapt. over the body. The hook, No. 8 or: 9 .

\section{THE YELLOW SALLY FLY.}

Comes on about the twentieth of May, and continues on till about the tench or twelfth of June. It is a four-winged Hy; as it swims down the water its wings lie flat on its back. The wings are made with a yellow cock's hackle, and the body of martin's fur, taken from the spots ander the jaws, which is a fine yellow. It is one of those fires that prepare ihe fish to look for the Iiray-ty, or Green-dratie. 'The hook, No. 7 .

THE OAF, ASH, TOODCOCK, CANNON, OR DOY VTHILLELY.

Comes on about the sirteenth of May, and continues on till about a week in June; it is to be found on the buts of trees, with its head always downwards, which gives it the name of the Down-hill-fy.* It is bred in oak-apples,

* Viule description of this ly, part Ist, under Natural F! yfising. 
and is the best of all flies for bobbing at the bush in the natural way, and a good fly for the dab-line, when made artificially. The wings are made from a feather out of the wing of a jartridge or woodcock, the body with a bittern's feather, and the head with a little of the brown part of hare's fur. 'Ihe hook, No. 7.

N. B. Some dub it with black wool and Isabella-coloured mohair, and bright brownish bear's hair, waped on with yellow silk, but the head of an ash columr; others dub it with an orange tawney and black ground; and others with blackish wool and good twist; the wings off the brown part of a mallard's feather.

\section{TIYE SITORN FLY.}

Comes on about the same time as the CannonAy, and continues on till the latter end of July. They are generally found in mowing grass; it is of the caterpillar kind, lias dusky wings of a dark brown colour, with fine clear blue wings under them, which it malies use of in its fight: it is in greatest perfection in June: and for the time that it continues on the water, is a most excellent killer in rivers or brooks. There are three sorts of them; the one I have described: there is another with a dull red wing: and a third with a dark blue wing, all of which the fish talie rery well, but the preference must be given to the red sort: it, is to be fished with any time of the day, from sun-rise to sun-set. 'The wings are made of a red cock's hackle, with a black list up the middle; the body with a peacock's herl. 'J'he hook, No.6, if for a rizer; 
but if for a dead, heavy, ruming brook, the fly must be made larger, as on No. 4 or 5.

\section{THE ORI FIY.}

Comes on the latter end of May, and confinues on till the latter end of Jine. It is a four-winged $\mathrm{Al}$, generally flutters along the surface of the water, and is what fishes are remarkably fond of; you may fish for it successfully after the May-fly is gone, from four o'clock in the morning, till about seven in the evening, at which time the sky-blue comes on, then change it for the sky-blue. The wings of the Orl-fy are made with a dark grizzle cock's hackle, and the body of peacock's herl, worked with dark red silk. The hook, No.6.

\section{TIIE SKY-COLOURED BLUR.}

Comes on about the same time as the orlfly, and continues on till the middle of July. It is a neat, curious, and heautiful fly; its wings are transparent, stand upright upon its back, and are of a fine blue colour, its body is of a pale yellow, its tail forked, and the colour of its wings; it is a fly the fishes take extremely well from seven o'clock in the evening till sunset. 'The wings are made from the light blue feather of a hen; the body is made with pale yellow mohair, mixed with light blue fur, and ribbed with a fine cock's hackle, dyed yellow. The hook, No. 8.

TIEE CADISS-FLY.

Comes on about the tenth of June; it is a large 
four-winged fy, of a buff colour, and its body the same colour of its wings: it continues on the water till about the middle of July; it is bred from the codbait, a curious little insect: while in the state of a grub it is greatly to be admired, the outside husk that it lives in, being curiously wrought with gravel nr sand: this Hy is taken best at the clearing of the water, though I think him a fly worth the least notice of any in the catalogue, there being many sorts fin preferable to it. The rvings are made from a feather taken from a buff-coloured hen; the body is made of buff-coloured mohair, and the legs of a pale yellow hackle. The hook, No. 6.

\section{THE BLUE GNAT.}

Comes on the water about the same time as the spinners (vide list the first under June) and continues on about a fortuight: if the water is low and fine the fishes take them very well, and as long as they remain on the water. The wings of this gnat are made of a small pale blue cock's hackle, and the body with light blue fur, mixcd with a little yellow mohair. The hook, No. 8 or 9.

\section{THE LARGE RED ANT-FLY.}

Comes on about the middle of June, if hot and sultry veather, and continues on until about the 15th or 16th of July, appearing mostly in hot, close, gloomy days: it is to be tished with. from about eleven o'clock in the forenoon, till about six in the evening; then make use of the cvening fites described before. 'The ant-flies, when in perfection, are great killers, and all sorts 
of fishes that rise at flies, are very fond of them; and you may take fish with them in dead heary waters, as well,as in streams. The wings of this fy are marle from a teather out of a siare's wing, and the body of peacock's heri, made pretty large at the tail, and fine towards the wing, with a fine ginger-coloured cock's hackle wrapt twice or thrice under the but of the wings. I'ke hook, No.8.

\section{TEE LARGE BLACK ANT-FLY.}

Comes on at the same time with the red, and is to be fished with at the same time, and after the same manner. The wings of this fly are made with the lightest sky-blue feather you can get, and with the greatest gloss; but it is difficult to find any that can come up to the glossiness of the natural wings, except the thistle, which makes them the best of any thing I know of, but is notlasting; the body is made with a black ostrich's feather, and a black cock's hackle wrapt nnder the but of the wings; it is to be made in the same form as the red one. The hook, No.8.

TIE HELSHMAN'S BUTTON, OR IIZLEFLY.

Comes on about the latter end of $\mathrm{J}_{H} \mathrm{l}_{y}$, and continues on about nine days; it is in form like a round button, from which it derives its name: it has four wings, the uppermost husky and hard, the undermost of a fine blue colour, soft and transparent; it is to be found on hazle-trees, $\mathrm{O}^{\prime \prime}$ fern: it is an excellent fly for bobbing at the bush, or dub line; but is rather difficult to make, on account of its shape and form; the wings are made from the red feather that grows upon the 
rump or tail of a partridge; the body is made with a peacock's herl, and an ostrich's feather mixed, and the legs of a fine black cock's hackle. The hook, No. $\%$.

THE LITTLE RED-ANDBBACK ANT-FLIES.

Come on about the tenth or twelfth of Angust, are to be seen in warm gloomy days, till the latter end of. September; to be fished with from about twelve o'clock, till fom in the evening, and are to be made in the same form as the large ones, and with the same materials, but very small. The hook, No.9.

\section{THE LITTLE WIIRLING BLUE.}

Comes on about the tenth or twelfth of Augrust, and continues on about three weeks; is it swims down the water, its wings stand upright on its back; it has a forked tail, the colour of its wings; it is to be fished with from eleven o'clock in the forenoon, till three in the afternoon. The wings are made from a feather out of the wings of a starling; the body is made with spaniel's fur, mixed with a little yellow, and a fine red hackle over the body. The hook, No.s.

\section{THE IITTLE PALE HLUE.}

Comes on about the same time as the Whirling blue, and continues on till about the latter end of September; as it swims down the water, its wings stand upright on its back; it has a forked tail, and the color of its wings: it is a reat, curious, little fiy, and what the graylings 
are very fond of: it is to be tished with from about ton o'clock in the moming, till three in the afternoon, and generally affords the angler great diversicn. The wings are made from a reather off the sea-swallow : the body is made of the lighrest blue fur you can ger, mixed with a very litale yellow mohair, with a fine pale blue hackle wrapt orer the body, The hook, No. 3.

\section{TIIE EIILIOW FEY.}

Comes nn about the beginning of September, and continues on till the latter end of Cetober: it is a fou:-winged fly, and generally fiutters mpon the surface of the water: it is to be fished with in cold stormy days, being then most plentiful on the water; but in warm gloomy days make use of the pale-blue. The wings are made of a blue grizzled cock's hackle, and the body of the blue part of squirrel's fur, mixed with a little yellow mohair. The hook, No. 7.

The three last-mentioned flies conclude the season for fly-fishing From the middle of May till August, you will find great variety of flies and grats upon the water every day, so that you must observe it as a general rule to fish with the first fly that comes on in the morning; that fly being the first which is on the water in the day that is first mentioned in every month, and then you will see the other flies and gnats, coming down every day in regular succession, every succeeding day till $\Lambda$ ugust. The great number of files and insects that are on the water, all the hot stimmer's months, and the great variety of 
food that fishes have, both at top and bottom, makes them very nice, and more difficult to be taken, than in the spring or in the autumn; the great number of flies and insects which are on the water all the summer months, totally disappear, about the middle of August, so that your diversion is as certain with the three autumnal flies, viz. the Little Whirling Blue, the Pale Blue, and the Willow-fly, as with the three spring flies, which are the Red-fly, the Blue Dun, and the Brown: In these two seasons of the year, if the weather is favourable, and the water in order, you will find your sport more certain and regular than in the hotter months. This last list of thies may be deemed the standard of artificial fly-fishing; they are the ingenious Bowlker's of Ludlow in Shropshire. For their ex cellency they are not to be equalled. They will kill fish in any county of England and Wales, and are, what I call the angler's lreasure. Their names are universally known: as for the flies called Lochaber's Golden Sooty's, \&c. \&.c. which are to be met with in a late publication, they are not sufficiently known to be of general use.

Not only those flies that are most useful, in the recreation of angling, but myriads more come under the angler's observation, when in pursuit of his pastime, which will not only fill his mind with wonder and admiration, at the incomprehensible works of Nature, but likewise make him praise that Almighty Power, from whom both himself and them derive their being.

There is so beautiful a passage a-propas to this subject, in Mr. Thomson's Summer, that I think the insertion of some part of it, must prove acceptable to the informed and pions mind: 
- Nor shall the muse disdain

To let the little lively summer-race

Live in her lay, and futter thro' her song:

Not mean, tho' simple; to the sun ally'd,

From him they draw their animating fire.

Wak'd by his warmer ray, the reptile young Come wing'd abroad, by the light air upborne, Jighter and full of soul. From ev'ry chink And secret corner, where they slept away Their wintry storms, or rising from their tombs To higher life, by myriads forth at once, Swarming they pour, of all the varied hues Their beauty-beaming parent can disclose. ren thousand forms, ten thousand different tribes,

People the blaze. To sunny waters some Fy fatal instinct fly, where or: the pool They sportive wheel; or falling down the stream, Are snatch'd immediate by the quick-ey'd trout Or darting salmon. Thro' the green-wood glade some love to stray, there lodg'd, amus'd, and fed, In the fresh leaf: luxurious, uthers make The meads their choice, and visit ev'ry flow's And ev'ry latent herb, for the sweet task To propagate their kinds, and where to warp, In what soft beds, their young, yet undisclos'd, Employs their tender care: some to the house, The fold, and dairy, hungry bend their fight, Sip round the pail, or taste the curdling cheese: oft, inadvertant from the milky stream They meet their fate, or well:ing in the bowl, With pow'rless wings around them warp'd, expire.

Resounds the living surface of the ground; Nor undulightin is the ceaseless hum

To him who muses through the woods at noon, Or drowsy shepherd as be lies reclind,

With hall-shut cyes beneath the floating shade of willows grey, close crovding o'er the brook.

Gradual from these what numerous kisids descend, Evading e'en the microscopic eye!

Full nature swarms with life, one wondrous mass Of anmals, or atoms organiz'd, Waiting the vital breath, when parent heav'n Sliall bid his spirit biow. 
Let no presuming impious railer tax Creative wistiom, as if aught was form'd In vain, or notfor admirahle ends:

Shall little haughty ignurance fronounce Ilis works unwise, of which the smallest part Exceeds the narrow vision of her mind?

\section{CHAP. $V$.}

\section{The best Rules for Artificial Fly-fishing.}

T $\mathrm{T}$ is the best fishing in a river soinewhat 1 disturbed with rain, or in a cloudy day, when: the waters are moved with a gentle breeze: the south and west winds are the best: and if the wind blows high, yet not so but that you may conveniently guide your tackle, the fishes will rise in the still deeps; but if there is little wind stirng, the best angling is in swift streams.

In casting your line do it always before you, and in such a manner that the fly may fall first on the water, and as little of your line with it as possible, but if the wind is high, you will then be forced to drown a good part of it, that you may keep the fly on the water; and endeavour, as much as you can, to have the wind at your back, and the sun in your face; but the winding of the river will frequently render that impracticable.

When you throw your line, wave the rod in a small circumference round your head and never make a return of it before it hus had its full scope, for if you do the fly will siap off.

Although when you angle the day is cloudy and windy, and the water thick, you must keep the fly in continual motion, otherwise the fishes. will discern the deceit. 
"Upon the curling surface, let it glide,

"With nat'ral inution from your hand supply'd, "Against the stream now gently let it play",

"Now in the rapid eddy flodt away."

Let the line be twice as long as the rod, unless the river is encumbered with wood: and always stand as far off the bank as the length of your line will permit, when you cast the fly to the contrary side; but if the wind blows so that you must throw your line on the same side you are on, stand on the very brink of the river, and cast your Ay at the utmost length of the rod and line, up or down the siream as the wind serves.

You must have a quick sharp eye, and active hand, to strike directly a fish rises: or else finding the mistake he will throw out the hook.

small light-coloured flies are for clear waters and clear atmospheres, large dark-coloured flies when rice versa.

When after rain the water becomes brownish, an orange-coloured fiy is taken greedily.

When fishes rise at the fly very often and yes never take it, you may conelude that it is not what they like: therefore change it for the one they do.

When you see a fish rise, throw your fly over him, and draw it gently over the place where he rose; and if it is a proper fly for the season, and you cast it with a nicety the fish is your own.

When you angle in slow-running rivers, or still places, with an artificial $f y$, cast it across the water, and let it sink a little in the water, and. then draw it gently over to you again, letting the current carry it slowly down: this is the best way for slow waters; but for quick ones your fly must always swim on the top, under the: 
continual inspection of your eyes, which ought, for this kind of angling, to be as sharp as the busilisk's.

It is a good plan to always carry some dubbing, gut, hooks, and silk, out with you in a small pocket book, that you may be able always to imitate any fly you see the fish rise at more than others.

The lighter your flies fall on the water the better; this you will, not accomplish by strength, but by practice, always raising your rod by legrees, after you have made your cast. A young angler should never use more than one fly on the stretcher at first, but when he can throw out pretty well, he may add to the stretcher one or more droppers, observing always to let them be one yard asunder.

I shall now conclide these rules by giving the reader a passage relating to artificial fly fishing, (with the alteration only of two or three monosyllables) from the Spring of that elegant and natural ciescriptive poet, $\mathbf{M r}$.'Ihomson, which cannot fail of contributing as well to his amusement, as instruction:

Soon as the first foul torrent of the brooks, Swell'd with the vernal rains, is ebb'd away, $\Lambda$ nd, whit'ning, down their mossy tinctur'd stream.

Descends the billowy foam, then is the time, While yet the dark-brown wateraids the guile, To tempe the trout. The well-dissembl'd Hy, 'To rod fine tap'ring, with elastic spring, Snatcil'd frum the hoary steed the floating line, And all thy slender wat'ry stores prepare; But let not on thy hook the lortur'd worm, Convulsive $t$ w ist in agronizing folds, Which, by rapaciuns hunger swallowed deep, Gires, as you tear it from the blceding brcast.

of the wean helpless uncomplaining wretch, 
Marsh pain and horror to the tencier hand. When with his lively ray the potent sun IIss pierced tire streams, and rous'd the finny race, Then, issuing cheertil to thy sport repair; Chief should the western breezes curling play, And light o'er ether bear the shadowy clouds. High to their fount, this day, amid the hills And woodlands warbling round, trace up the brooks; 'Then next pursue their rocky channel'd maze Down to the river in whose ample wave Their little naiads love to sport at large. Just in the dubious point, where with thie pool Is mix'd the trembling stream, or where it boils Aromd the stone, or from the hollow bank Reveried plays in undulating flow, There throw, nice judging, the delusive fly, And as you lead it round in artful curve, With eye attentive mark the springing game: Straighi as above the surface of the food They wanton rise, or urged by hunger leap, 'Then fix with gentle twitch the harbed hook; Some lightly tossing to the grassy bank; And to the shelving shore slow dragging some, With various hand, proportion'd to their force. If yet too young, and easily deceiv'd, $A$ worthiess prey scarce bends your pliant rod, Him piteons of his youth, and the short space He has enjoy'd the vital light of heav'n, Soft disengage, and back into the stream The speckled captive throw; but should yon lure From his dark haunt, beneath the tangled routs. Of pendent trees, the monarch of the brook, Behoves you then to ply your finest art: Long time he, following cautious, scans the fly, And oft attempts to seize it, but as oft The dimpl'd water speaks his jealous fear: At last; while haply over the shaded sun Passes a cloud, he desperate takes the death With sullen plunge: at once he larts along: Deep struck, and runs out all the lengthen'd line, Then seeks the farthest aoze, the sheltering weed, The cavern'd bank, his old secure abode; And flies aloft, and flounces round the pool, Indignaint of the guile. With yielding hand, That feels him still, yet to his furious course 
Gives way, $j u$, now retiring, following $130 \mathrm{w}$ Across the stream, exham this idle rage, Till floating broad upon his breath!css side, And to his fate abandon'd, to the shore You gaily drag your unresisting prize.

\section{CHAP. VI.}

* Of the principal Rivers in England, and parli. cularly of the Thames.

7 THE rivers in England are said by Dr. Helylin, to be three hundred and twenty-fire, though others increase their number to four hundred and fifty. It would be superfluous here to treat particularly of their diversities, their situations, their distance and remoteness from each other, their nearness or vicinity to the sea, the qualities of their water, and the various species of fish they contain. Those that have a more immediate intercourse with the sea, partake of its influences, and have the same vicissitudes, the same fluxes and refuxes, the same salt water, and the same sort of fish which frequent those seas where they disembogue themselves. The mouth of rivers are too deep to be fathomed by the cordage of a line; but more inland and farther distant from the common receptacle of waters, the rivers are most proper for the angler's diversion.

'The principal rivers in England, are the Thames, Severn, Trent, Tyne, Triced, Medway, Tees, Dove, Isis, Tame, Willey, Aron, Lea,

* The angler must oloserve, that the uames of Wye, Avon, Ousc, Slone, and some others, are common to many rivers in England, as that of Dulus is to numbers in Wales. 
Trevel, Lon, Nen, Welland, Darvent, Calder, Wharf, Nid, Don, Swale, Hull, Ouse, and Are. The rivers in Wales are reckoned above two hundred, the principal of which are the Dee, Wye, Conwy, Tivy, Chedlayday, Cluid, Usk, Tovy, Taft, and Dovy. Several rivers in England run under ground and then rise again, as a branch of the Medway in Kent; the Mole in Surry; Hans in Stafiordshire; the little rivers Allen in Denbighshire, and Deverelin Wiltshire; the river Recall hides itself under ground, near Elmsley in the North-Riding of Yorkshire; at Ashwell in Bedfordshire, rise so many sources of springs that they soon drive a mill; at Chedder, near Axbridge in Somersetshire, is a spring that drives twelve mills in a quarter of a mile. In the midst of the river Nen, south of Peterborough in Northamptonshire, is a deep gulf, called Mcdeswell, so cold, that in summer no swimmer is able to endure it, yet is not frozen in the winter.

I shall now give the angler the names of the rivers in our Counties.

Bedfordshire. The Ouse navigable to Bedford, and divides the county into two parts; the Ivel, Tiea, and other smalle: streams.

Berkshire. The Thames, Isis, Kennet, Loddon, and the Lambourne; the latter, contrary to all others, is always the highest in summer, and lowcst when winter approaches.

Buckinghamshire. 'The Thames, Ouse, Coln, Wickam, Amersham, Isis, Tame, and Loddon.

Cambridgeshire. The Ouse, Cam, Welney, and Neve.

Cheshire. Principal rivers; the Mersey, Dee, Weelock, Croke', Dan, Fulbrook, Wever, Goyte Bolling, and Fingay. 
Cornwall. The Tamer, Cober, Loo, Camel, Lydd, Fowey, Haile, and Liver.

Cumberland. Principal rivers; the Eden, Aln, Jet, Petterel, Cande, Derwent, Cocker, Duddon, Levin, Esk, Wiza, and Tyne.

Derbyshire. Principal rivers; the Derwent, Trent, Wye, Erish, Crawlock, Dore, Compton, Rother, Ibber, and Nore.

Devonshire. The Tame, Exe, Plym, Torride, Taw, Yalm, Otter, Oke, Dart, Tivy, Aven, Erme, Calme, Teigne, $A x$ and Loman.

Dorsetshire. The most considerable rivers are the Froom, Brit, Piddle, Stour, and Lirldon.

Durham. The principal rivers are the Tees, Tyne, Were, 'Tame, Lune, Derwent, Gaunless, and Skern.

Essex. The principal rivers are the Thames, Black WVater, Stour, Coln, Lea, Crouch, Chelmer, and Roding.

Glocestershire. The Severn, Wye, Coln, Chein, Stroud, eminent for dying scarlet; lsis, Arons, Fromes, Siviliate, Caron, Winthush, Evondole, Lecien, Lathe, Ishourne, Chilt, Badgworth, Evelm, B'erkley, and Trim.

Hampshire. Its principal rivers are the Ithing, or Alre, the Tees, or Test, Anton, Aron, Stout, Wey, Loddon and Auborm.

Herefordshire. Its rivers are the Wye, Lugg, Munnow, Arrow, Frome, Doir, Leddon and Tame.

Hertfordshire. The principal rivers are the Sea, Coln, Stort, Gade, Liean, Tame, Ribb, and the New River, which supplies London with water.

Huntingdonshire. The principal rivers are the Ouse, Nen, and Cam, with some smailes. stieams. 
Kent. Its rivers are the Thames, Medway, Stour, Rolher, Darent, Tun, Ravensbourne, and Wantshcim.

Lancashire. Its principal rivers are the Duddon, Crake, Leven, Winster, Lon or Lune, Wyer, Calder, Hodder, Wenning, Ribble, Douglass, Yarrow, Darent, Trevell, Roch, Alt, Tame, Medlock, and Irk.

Leicestershire. Its chief rivers are the Stour, Welland, Wreck, Aron, Anger, Swift, Seme, and the Eye.

Lincolnshire. The principal rivers are the Humber, Trent, Witham, Welland, Ancam, Bane, Nen, Dun and Idle.

Middlesex. The Thames, Lea, Coln, Brent, and the New River.

Monmouthshire. The principal rivers are the Severn, Monow, Wye, Usk, Rimney, and Aron.

Norfolk. The rivers are the greater and lesser Ouse, Wesbech, the Yore, Wareney, Wensor, Thyrn, Lynn, and some lesser streams.

Northamptonshire. The principal rivers are the Ouse, Nen, Welland, Chenvill, and the Leam.

Northumberland. Its rivers are the Tweed, Tyne, North and South Tyne, Alne, Wensbech, Coquet, Bramish, Usway, Blythe, Till, East and West Alon.

Nottinghamshire. The principal rivers are the Trent, Lyn, Ryton, Leane, Idle, Erwash, Meden and Maun.

Oxfordshire. Its principal rivers are the Thames, Cherwell, Isis, Tame, Swere, Clin Rer, Oke, Windrush, Evanlode and Sorbrook.

Rutland. The rivers are the Gnash, Eye, Chater, and Welland. 
Shropshire. The principal rivers are the Tweed, Severn, Teem, Clun, Ony, Warren, Tern, Corve, Rea, Kemlot, and Melo.

Somersetshire. Its principal rivers are the Severn, Ivil, Avon, Ax, Car, Exe, Frome, Brent, Parret, Brue, and Tone.

Staffordshire. Its principal rivers are the Trent, Manyfold, Chernet, Lime, Perik, Stove, Tern, Dore, Boine, Sow, Blith, Team, and Sinestall, with very extensive navigable canals.

Suffolk. 'J'he principal rivers are the Stour, Bret, Larke, Little Ouse, Orwell, Deben, Butley, Alde, Waveney, and Blyth.

Surry. Its principal rivers are the Thames, Wandel, Mole, Wey, and Loddon.

Subsex. The most considerable rivers are the Cockmere, Little Ouse, Rother, Adur, Rye, and Arun.

Warwickshire. Its principal rivers are the Aron, Tame, Alne, Anker, and Cole.

Westmoreland. The principal rivers are the Eden, Ken, Lune, Tees, Relo, Lowther, Roatha, and Emont; besides Ulles, Broad and Horn's waters, and that extensife piece called Wynander Meer, the largest in England, being 10 miles long, and 2 broad, with several islands in it, and its bottom one continued rock.

Wiltshire: Its chief rivers are the two Avons, the Kennet, Willey, Adder, Nadder, Duril, Were, Calne, Rey, Welleborne, and the Thames, one of whose heads is in this county.

Worcestershire. The principal rivers are the Severn, Avon, Teem, and Stour, but enjoying the benefit of some of the late constructed canals, it has, by the inland navigation, communication with the most considerable rivers in the kingdom; which navigation, including its wind. 
ings, extends above 500 miles through different counties.

Yorishire. Its rivers are the Humber, Ouse, Youre, Wharf, Swale, Tees, Nid, Calder, Aire, Hull, Dunderwent, Rye, Whisk, Ribble, Esk, Skeller, Recall, Lune, Barnes, Went, Rother, Greta, Foulney, and Leven.

North Riding of Yorkshire. The principal rivers in this Riding are the Ure, Wharf, Swale, 'Tees, Don, Lme, Pye, Whisk, Eden, Esk, Codleach, Leven, and Recal, with the North Bank of the Derwent.

Last Riding of Yortishire. The most considerable rivers in this division are, the Humber, Iull, Ouse, Derwent, and Foulness.

West Riding of Yorkshire. The chief rivers are the Ure, Don, or Dune, Went, Calder, Aire, Ribble, Wharf, Dearn, Nidd, and Hodder; with a variety of smaller streams.

\section{RIVERS IN NORTH WALES.}

Anglesey. The principal rivers are the Menai, and IS eveny.

Carnarvonslire. Its principal rivers are the Conway, and the Seint; it has also several lakes.

Denbighshire. Its principal rivers are the Cluyd, Dee, Conway, Allen, Keriog, Kelyn, and Elwy.

Fintshire. The principal rivers are the Dee, Cluyd, Elwy, and Allen; the most remarkable places are the Dee's Mouth, the Cluyd's Mouth, and St. Winifred's Well.

Merionetshire. Its principal rivers are the Dee, Douay, Avon, and Deaunny.

Montgomeryshire. The most considerable nivers are the Severn, Rayder, Turgh, and Tanet. Verniew, and some smaller streams. 
TIE RIVERS IN SOUTH WALES.

Brecknockshire. Its principal rivers are the Hodney Wye, Usk, and the Yrvon.

Cardiganshire. Principal rivers are the Tavy, Rhidal, and Iswith.

Carmarthenshire. Its principal rivers are the Tavy, Cathy, Towy, Brane, and Gwilly.

Glamorganshire. 'The chief rivers are the Taff, Rhymmy, Ogmore, Avon, Cledaugh, and Tavy; also a warm spring called Tave's Well, and Swansea mineral spring.

Pembrokeshire. Its rivers are the Cletby, Dougledye, and the Tavy, with several lesser streams.

Radnorshire. The most considerable rivers are the Wye, Lug, Turne, Arrow, Somergill, Tame, and several small streams. On the $W$ ye is a remarkable waterfall, called Rhajadi-gwy. There is also an excellent mineral spring at the village of Llandrindod.

As the maps will give a better prospect of these than any enumeration of them can do, let every angler have a large one of England, or at least of the particular county where he usually angles, and therein he may with delight observe the spring head, scite distance, various passages, windings, turnings, and confluses of each particular river, with what towns, castles, churches, gentlemen's seats, and places of note, are on or near the banks; making; as he angles, remarks proper to the nature of each.

The six principal rivers are as follow:

1. The Thames, compounded of two rivers, Tame and Isis. The Tame rises in Bucks, beyond Tame in Oxfordshire, and the latter in Cotswold-hills, near Cirencester in Gloucester- 
shire. They meet together about Dorchester in Oxfordshire, and thence run united betwixt that county and Bucks, and between Buckinghamshire, Midâleser, and Essex, on the one side, and Surry and $K \in \ln$ on the other, wedding itself to the Kentish Medway in the very jaws of the ocean. This river is said to feel the violence and benefit of the sea more than any other river in Europe, ebbing and flowing twice a day, more than sixty miles. Sir John Denham has given so grand a description of the Thames, in his Cooper's-hill, that I think the insertion of some purt, cannot prove unacceptable to the reader:

II y cye descending from the hill, surveys

Where Thames among the wanton vallies strays:

Thames! the most lov'd of all the ocean's sons

$\mathrm{By}$ his old Sire to his embraces runs,

I lasting to pay his tribute to the sea,

like mortal life to meet eteruity ;

Tho' with those streams he no resemblance hold, Whose foam is amber and their gravel guld: His genuine and less gnilty wealth t' explore, Search not his bottom, but survey his shore;

O'er which he kindly spreads his spacious wing, And hatches plenty for the ensuing spring; Wor then destroys it with too fond a stay, Lise mothers which their infants overlay:

Nor with a sudden and impetuous wave, Like profuse kings, resumes the wealth he gave.

No mexpecteri inundations spoil,

'Tlie mower's hopes, or mock the ploughman's tcil;

But god-like his unweary'd bounty hows:

Firstlures to do, then loves the gord he does.

Nor are his blessing's to his banks confin'd,

3ut free and common as the sea ur wind;

When he, to boast or to dieperse his stores Full of the tribute of his grateful shores, Visits the world, and in his fying tow'rs, Brings home to us, and maxes both Indies ours, Finds wealth where tis, bastows it where il wants,

Citier in deserts, rvools in cities, plints. So that to us no thing, nopiace, is strange, Fibile his fitir Dosom is the worid's exchange. 
The second river of note is the Severn, which has its beginning in Plinilimon-lill, in Montgoineryshire, and its end seven miles from Bristol; washing in that space the walls of Shrewsbury, Worcester, Gloucester, and dirers other places and palaces of note. It receives greater rivers, and is farther navigable than the Thames, but does not equal it for the quantity and quality of its fish.

3. The Trent (so called on account of the thirty different kinds of fish which are found in it, or because it receives thirty small rivers) has its fountain in Stafiordshire, and gliding through the counties of Nothingham, Lincoln, Leicester, and York, augments the turbulent current of the Humber, the most violent strean of all the isle. The Humber is not a distinct river, because it has not a spring liead of its own, but is rather the mouth or cesluarium of divers rivers meeting together; among which besirles the Trent, are the Dirrent and Ouse.

4. The Medway, a Kentish river, rises near Tunbridge, passes by Maidstone, runs by Rochester, and discharges itself in to the mouth of the Thames, by Sheerness; a river chiefly remarkiable for the dock at Chatham, where ships of the first rate are built and repaired for the use of the English navy.

5. The Tweed, the north-east boundary of England, on whose banks is seated the strong and almost impregnable town of Berwick.

0 . The Tyne, famous for Newcastle and its inexhaustible coal-pits. These, and the rest of principal note, are thus described in one of $\mathrm{Ml}$. Brayton's sonucts : 
1.

The flood's Queen Thames, for ships and swans is. crown'd,

And stately Severn for her shore is prais'd;

The chrystal Trent for fords and fish renown'd,

And Ayon's fame to Albion's cliffs is rais'd:

G.

Carlegion Chester vaunts her holy Dee :

York many wonder's of her Ouse can tell:

The Peak her Dove, whose banks so fertile be,

And Kent will say, her Medway doth excel.

3:

Cotswold commands her Isis to the Tame:

Our northern borlers boast of Tweed's fair flood:-

Our western parts extol their Willy's fame,

And the old Lea brags of the Danish blood.

But let me return to the Thames, of which, and the rivers that fall into it, $I$ shall treat somewhat. particularly, as they are more the seat for the diversion of angling than any others. The higher an angler goes up the Thames, if within about forty miles, the more sport, and the greater variety of fish he will meet with; but as few Londoners goes far from home, I shall mention the best places for Thames angling from London Bridge to Chelsea.

But before I proceed any farther on this sub. ject, it will be necessary to lay down some rules. which the angter must attend to.

If the air is cold and raw, the wind high, the water rough, or if the weather is wet, it is totally. useless to angle in the Thames.

But when the sky is serene, the air temperate, and the water smooth success will attend you. 
The proper hours for angling, are from the time that the tide is half ebbed, to within two hours of the high water, provided the land floods do not come down.

Always pitch your boat under the wind: that is, if the wind be in south, then keep on the Surry shore; if north, on the London side.

rThe best places for pitching a boat to angle in the Thames, are about one hundred and fifty yards from York Stairs; the Savoy, Somersethouse, Dorsct Stairs, Black-Friar's Stairs; the Dung-Wharf near Water-Lane, Trig Stairs, and Essex Stairs. On Surry side Falcon Siairs; Barge Houses; Cuper's, rulgo Cupid's Stairs; the Wind-mill and Lambeth.

There are very good roach and dace to be caught at Westminster Bridge, if the weather is favourable in the Autumn; the fifth arch on the north-side is best to pitch the boat.

When you go to angle at Chelsea, on a calm fair day, the wind being in a right corner, pitch your boat almost opposite to the church and angle in the six or seven feet water, where, as well as at Battersea Bridge, you will meet with plenty of roach and dace.

Mortlake Deeps is the next place where roach principally resort, when the weeds are rotten; and here are good carp very often taken.

From the sides of the Aits opposite to Brentford, Isleworth, and 'Twickenham, there is very good angling for rouch, duce, gudgeons and perch; very often you will meet with trout and carp.

Teddington Banks are remarkable for good gudgeon, roach, \&c.

Kingston-wick and Kingston, are famous for barbel, roach, and dace.

At Hampton and Sanbury there is good ang- 
ling for barbel, roach, dace, chub, grudgeons, and sheggers; and from the Aits, for truut and large percik.

Walton Deeps and Shepperton Pool abound with large barbel and dace.

At and about $W$ indsor is a variety of all sorts of fish; but if a man be found angling in another's water, (without leave) he is fned very high by the court of that town, if he only catches a single gudgeon, \&c.

Of the rivers that empty themselves in the Thames, and of others which are not far from it, I shall begin with those on the north-side.

1. Ilford-river, the upper part of which abounds with roach, dace, and some perch, but between Ilford ard the Thames, especially about three miles from the town, there is pike.

a. Woodford-river, stored with perch, chub, roach, and dace.

3. Stratford-river affords the angler good diversion for roach, dace, chub, perch, \&s.

4. Bow-river, having the same fishing it as the Stratford-river.

5. Hackney-river, having plenty of large barbel, chub, roach, dace, gudgeon, eels, and lampreys. In this river the barbels, eels, and gudgeon, are rely fine. The river Lea runs here, and the higher you go up it the greater sport you will have: The Rye-house, near Hoddeston (fimous for the plot) is an excellent part to go for diversion.

6. Waltham-river, besides large barbel, chu!b, rouch, dace, gudgeon, and eels, has good store of fine pike, and some carp.

7. The New-river, pretty well stored with chub, roach, dace, gudgeon, and eels.

s. Brentford-river, a good one formerly, but 
now much abused by poachers; but the angler may meet with somc chub, roach, dace, and perch.

9 . Hounslow-river, well stored with roach, dace, perch, pike, and guadgeon.

The powder-mill tail, near Hounslow is a very good place for angling.

10. Colne-river, abounding with chub, roach, dace, perch, and pike.

11. Uxbridge-river, excellent for its large and fat trouts; but as the water is rented, not only leave must be obtained to angle in it; but you must pay so much per pound for what you kill. Denham, near Uxbridge, is a very famous place.

Having now done with the north side, I proceed to the south of the Thames.

1. Deptford-river, now very much decayed, and has but a few fish in it, as rouch, clace, and flounders; though by chance you may meet with a trout.

2. Lewisham-river in which are some good trouts, large roach, chub, gudgeon, perch, and dace.

3. Wandsworth-river, well stored with gudgeons, dace, flounders, perch, pike, and sone curp and trouts; very large silver eels are often taken there.

4. Mitcham-river; its principal fish are trouts.

5. Merton-river, for trouts ilso.

6. Carshalton-river, abounding with trouts, and other white fishes.

7. Moulsey-river, yielding perch, jack, roach, dace, chub, gindgeons, eels, flounders, barbels, and trouts.

8. Esher-river, good for jacks, perch, chub, roach, dace, gudgeons, eels, fluunders, barbeis, and trouts.

9. Cobham-river, stored with plenty of good 
trouts, fat and large, as also dace, perch, chubs, jacks, and gudgeons.

10. Weybridge-river, affording good diversion for carp, some of which weigh eight or nine pounds; also jack, roach, dace, flounders, popes, large bleak, barbel, and gudgeons.

11. Byfleet-river, wherein are very larche pikes, jacks, and tench; perch, of eighteen inches long; good carp, large flounders, bream, roach, dace, gudgeons, popes, large chub, and eels.

I shall conclude this account of the Thames, and the principal rivers that fall into and compose it, with the following beautifullines of Mr. Pope

First the fam'd authors of his ancient name, The winding Isis, and the fruitful Thame;

The Kennet swift, for silver eels renown'd;

'The Lodden slow', with verdant alders crown'd, Cole, whose dark streams his flow'ry islands lave; And chalky Wey, that rolls a milky wave:

The blue transparent Vandalis appears;

The gulfy Lea his sedgy tresses rears;

And sullen Mole, that hices his dividing food;

And silent Darent, stain'd with with Danish blood.

\section{CHAP. VII.}

OF THE GAHE LAWS RELATING TO ANGIING.

1st. The Penatiy of Fishing in Ponds and other private Fisheries.

1. NY man may erect a fish-pond withA cut licence, because it is a matter of profit for the increase of victuals. 2. Inst. 199.

2. If any trespassers in ponds be therefors 
attainerl at the smit of the party, great and linere amends shall be awarded according to the trespass; and they shall have three years imprisonment, and after shall make fine at the hing's pleasure, (if they hac whereof) and then shall full good surety that after they shall not commit the like trespass: and if they have not whereof to make fine, atier three years imprisonment, they sluall find like surety; and if they canat find like surety, they shall abjarc the realm. And it none sue within the year and day, the king shalt I have suit. 3. Ed. I c.20. Nute, those are trespassers in ponds, who endeavour to take tish therein. 2. Inst. 200.

3. If aur person shall unlaw fuliy break, cut, $\mathrm{ol}$ destroy, any head or dam of a frish-pond, or shall wongfully fish therein, with intent to take and kill fish, he shall on conviction, at the suit of the king, ne of the party, at the assizes or sessions, be imprisoned three months, and pay treble damages; and after the three momiths is expired shall find sureties for his good abcaring for seven years, or remain in prisun till he doth, 5. El. c. 21 . S. 2.6 .

4. Whereas divers idle, disorderly, and mean persons, betake themselves to the stealing, taking, and killing of fish, out of ponds, pools, motes, stews, and othor several waters and rivers, to the great damage of the owners thercof; it is enacted that it any person shall use any net, angle, hair, noose, troll, or speal: or shall lay any wears, pots, fish hooks, or uther engines; or shall take any fisls by any means or device whatever, or by aiding thereunto, in any river, stew, pond, mote, or other water, without the consent of the lord or owner of the water; and be thercot convicted by contession, or oath of one witness 
before one justice, in one month after the offence, every such offender in stealing, taking, or killing fish, shall for every such offence give to the party injured such recompence and in such time as the justice shall appoint, not exceeding treble damages: and moreover shall pay down to the overseers for the use of the poor, such sum, not exceeding 10s. as the justice shall think meet; in default of payment, to be levied by distress; for want of distress to be committed to the house of correction, not exceeding one month, unless he enter into bond with one surety to the party injured, not exceeding $£ 10$. never to offend in like manner, 22 and 23 C. 2. c.25.s.7. And the justice may take, cut and destroy all such angles, spears, hairs, mooses, trolls, wears, pots, fish-hooks, nets, or other engines, wherewith such offender shall be apprehended. S. 8 .

Persons aggrieved may appeal to the next sessions, whose determination shall be final, if no title to any land, royalty, or fishery, be therein concerned. S. 19.

5. Whereas, divers idle, disorderly, and mean persons have and keep nets, angles, leaps, piches, and other engines, for the taking and killing of fish out of ponds, waters, rivers and other fisheries, to the damage of the owners thereof; therefore no person hereafter, shall have or keep any net, angle, leap, piche, or other engine for the taking of fish, other than the makers and setters thereof, and other than the owner and occupier of a river or fishery ; and except fishermen and their apprentices lawfully authorized in navigable rivers. And the owner or occupier of the river or fish; and every other person by him appointed, may seize, detain, and keep to his own use, every net, angle, leap, piche, and other engine, which he shall find used or laid, or in the 
passession of am person fishing in any river or fishery, without the consent of the owner or occupier thereot. And also, any person, authorized by a justice's warlant, may in the day-lime search the houses, out-houses, and other places, of any person hereby prohibited to have or keep the same, who shall be suspected to have or keep in his custody or possession any net, angle, leap, piche, O* other engine aforesaid, and seize and l:eep the same to his orw use, or cut and destroy the same, as things by this act prohibited to be kept by persons of their degree. 4 . and $5 . W$. c. 23. s. 5.6 .

6. If any peron shall enter into any park or paddock, fenced in and inclosed, or into any garlden, orchard, or yard, adjoining or belonging to any dwelling-house in or through which park or paddock, garden, orchard, or yard, any streain of water or river shall run or be, or wherein shall be any river, stream, pool, pond, mote, stew, or other water, and by any ways, means, or advice whatever, shall sieal, take, kill, or riestroy any fish bred, kept, or preserred therein, without the consent of the owner thercol; or shall be aiding or assisting therein; or shal receive or buy any such fish, knowing the same to be stolen or taken as aforesalid; and shall be convicted therenf at the assizes, within six calendar months after the offonce committed; he thall be transported for scren years. And any offender surrendering himscif to a justice, or being appre hended, or in custody for such offence, Or on any other account, who shall make confession thereof, and a true discovery, on oath, of his accomplice or accounplices, so as such accomplice may be apprehended, and shall on trial give evidence so as to convict such accomplice, shall be dis- 
charged of the offence so by him confessed. 3. G.3. c. 14. s. 1, 2.

And if any person shall take, kill, or destroy, or attempt to take, kill, or destroy, any fish in any river or stream, poud, pool, or other water (not being in any parts or paddock, or in any gatden, or orchard, or yard, adjoining or belonging to any dwelling-house, but in any other inclosed ground, being private property) he shall, on conviction before one justice, on the oath of one witness, forfeit 51. to the owner or owners of the fishery, of such river or stream of water, or of such pond, pool, mote, or other water: and such justice, on complaint, upon oath, may issue his warrant to bring the person complained of before him; and if he shall be convicted before such justice, or any other justice of the county or place, he shall immediately after conviction pay the said penalty of 51 . to such justice, for the use of such person as the same is hereby appointed to be paid unto; and in defanlt thereof, shall be committed by such justice to the house of correction, for any time not exceeding six months, unless the forfeiture shall be sooner paid; or such owner of the fishery may bring an action for the penalty (within six calendar months after the offence) in any of the courts of record at Wesminster. S. 3, 4 .

Provided, that nothing in this act shall extend to subject any persons to the penalties thereof, who shall fish, take, or kill, and carry away, any fish in any river, or stream of water, pond, pool, or other water, wherein such person shall have a just right or clain to take, kill, or carry away such fish. S. 5 .

7. By the black act, if any person, being armed and discuised, shall unlawfully steal ox 
take an wy any hish out of any rifes or pond; or (whether amed or disguised or not) shall unlawfully and malicionsly break down the head or mound of any fish-poud, whereby the fish shall be lost or destroyed, or shall rescuc any person in custody for such offence; or procure iny other to join wihh him therein, he shall be guiliy of felong, without benefit of clesgy.

Odly. RULES COYCERNING TIIE ASSIZE, AND PRESERITYG THE BIEED OF FISIL.

1. If any person shall lay or draw any net, enrine or other device, or cause any thing to be done in ibe Severn, Dee, Wyc, Teame, Were, Tees, Ribble, Mersey, Bun, Air, Ouze, Swale, Catder, Whate, Eure, Dancul, or Thent, whereby the suran or firy of salmon, or any kepperor sediter satmon, or any satmon not 18 inches from the eye to llar extent of the middle of the tail, sira!l be taken and killed; or shall set any bank, dam, had:- stank, or net acruss the simue, whereby the salmon mily be taken, or hindered from pitssing up to spawn, or shal! between July 31 , and November 1.), (except in the Ribble, where they maty be latien between Jan. 1, and sept. ! j, ) take anl sations of any kind in any of the said rivers, or shall, after Hov.12, yearly, fish there for salmon, with any ncl less dhan $2 \frac{1}{2}$ inches in the unestr; hestall, on conviction, in one month, before one justice, on view, confession, or onth of ore witness, forteit 51 . and the fish, nets and engines; haif the said sum to the intormer, and half to the poor, by distress; for want of distress, to be committed to the house of correction or gaol, not more than three months, nor less than one, to be kept to hard labour, and to suffer such (1) 3 
other corporal punishment as the justice shall think fit: the nets and engines to be cut or destroyed in presence of the justice; the banks, cams, hedges, and stanks, to be demolished at the charge of the offender, to be levied in like manner: 1 G. st.2. c. 18. s. 14 . Note. It is not said who shall have the fish; so that it seemeth they are forfeited to the king.

And no salmon out of the said rivers shall be sent to London, under six pounds weight; on pain that the sender, buyer, or seller, on the like conviction, shall forfeit 51 . and the fish; half to the informer and half to the poof, by distress; for want of sufficient distress, to be committed: to the honse of correction or gaol, to be kept to. hard labour for three months, if not paid in the mean time. Id.S. 15.

And persons aggrieved may appeal to the next Sessions. Id. S. $1 \%$

2. No salmon shat be taken in the Humber, Olize, Trent, Done, Aire, Darwent, Wharfe, Nid, Yore, Swale, Tees, Tine, Eden, or any other water wherein salmon are taken, between Sept. 8 and Nor. 1). Nor shall any young salmon be taken at millpools (nor in other places, 13. R. 2. st. 1. c 19.) from Mid-April to Midsummer, on pain of having the nets and engines burnt for the first ofrence; for the second, imprisonment for a quarter of a year: for the third, a whole. year; and, as the tresspass inereaseth, so shall the punishment. And overseers shall be assigned. to enquire thereof. 13. Ed. 1. st. 1. c. $4 \%$ That is, under the great seal, and by autlrority of parlament. 2. Inst. 477 .

And no person shall put in the waters of Thatmise, Humber, Ouze, Trent, nur any other waters, in any time of the year, any nets called 
stalliers, nor other nets or engines whatsoever, by which the firy or breed of salmons, lampreys, or any other fish, may in any wise be taken and. destroyed: on the like pain. 13. R. 2. st. 1. c.19.

And the waters of Lon, Wyre, Mersey, Ribble, and all other waters in Lancashire, shall be put in defence as to taling of salmon from Alichaelmas, to Candlemas, and in no other time of the year. And conservators shall be appointed in like manner. 13. k. Q. st. 1. c. 19.

And the justices of the prace (and the mayog. of London, on the Thanes and Medway, shall surrey the offencen in both the acts abore-menttioned; and shall survey and serech all the wears. in such rivers; that they shall not be very strait for the destruction of such fry and brood, but of reasonable wideness afier the old assize used os: accustomed; and they shall appoint under-conservators, who shall be sworn to make like survey, search, and punishment. And they shall enquire in sessions, as well by their office, at at the information of the under-eonservaturs, of all. defaults aforesaid, and shall cause them which: shall be thereof indicted, to come before them; and if they be thereot convicted, they shall have imprisonment, and make fine at the discreion of the justices: and if the same be at the information of an under-conservator, he sha! have lialf the fine. 17. R. 2. c. 9.

3. By the 1 Eliz. c. 17. No person, of what estate, degree, and condition soever be be, shall take and kill any young brood, spawn, or fry of fish; nor shatl take or kill any salmon or trouts, not being in season, being hepper and shedder; nor any pike or pilierel, not being in length ten juclues fish or more; nor any salmon, not being 
in length sixteen inches fish; nor any trotit notbeing in length eight inches fish; nor any burbel not beingin length tive re inches: and no person shall foh, or take fisin, by any device, but on!y with a net or trammel, whereof the mesh shail be wo inches and a half broad, (angling escepted, and except smelis, lorhes, minnows, bull heads, gadgeons, and cels;) on pain of forfeiting 20s. for every offence, and also the fish, nets, and engines. Note. In some editions of the statutes it is 201 . in others 20. . in the recoris it is not distinguishable whether it is pounds or shillings. The brtic: seems more adegunte to the offence.

And the conservators of rivers may enquire hereof by a jury; and in such case they shall have the fines.

The leet also may suquirc hereof; and then. the forfeiture shall go to the lord of the leet. And if the steward do not charge the jury therewith he shall forfeit 40s. balf to the king, and larif to him that shall sue. And if the jury conceat the offence, be may impannel anotber jury to enquire of such concealment: and if it is found, the former jury shall forteit every one ons. to the lord of the leet.

And if the offerce is not presented in the leet within a year, then it may be heard or determined at the sessions or assizes, (saving the right conservators.)

And by the $33 \mathrm{G}$. 2.3.97. No person shall take, ar knowingly have in his possession, either in the or water on shore, or sell or expose to sale, any spawn, fry, or brood of fish, or any mizizable fish, or fish out of season, or any smelt not five inches long: and any person may scize the same, together with baskets and package, and charge 
a constable, or other peace-officer, with the offender and with the goods, who shall carry them before a justice; and on conviction before such justice, the same shall be forfeited and delivered to the prosecutor; and the ofiencier shall besides forfeit 20 s. to be levied by distress, by warrant of such justice, and distributed, half to the prosecutor, and half to the poor of the parish where the offence was committed, (and any inlaabitant of such parish, nevertheless may be a witness), for want of sufficient distress, to be committed to the house of correction, to be kent to hard labour for any time not exceeding three months, unless the forfeiture be sooner paid. Provided, that the justice may mitigate the said penalty, so as not to remit above one half. Persons aggrieved may appeal to the next sessions: And the form of the conviction may be this:

Be it remembered, that on this day of in the year of the reign of $\quad G . B$. is convicted before me one of his majesty's justices of the peace, for the of for and I do adjudge him to pay and forfeit the sum of Given under my hand and seal the day and year abovesaid. S. $13,15,16,17,18,19$.

4. No person shall fasten any nets over rivers, to stand continually day and night, on pain of an hundred shillings to the hing. 2 II. 6. c. 15.

Our plenteous streams a various race supply, 'The bright ey'd perch, with fins of Ty lan-dye, 'The silver cel, in shining rolumes rull'd, 'The yellow carp, in scules be-dropp'd with gold, Swift trouts, diversified with crimson stains, And pikes, the iyrants of the wal'y piains. 


\section{CHAP. VIII.}

Prognostics of the rieather, independent of the the Barometer, extracted from the best Authorities.

A $S$ it is highly necessary that an angler A should be able to form a judgment of the change of weather, on which his sport entirely depends; if he observes the following signs, it will soon become familiar to him.

\section{STGNS FROAT VAPOURS.}

If a white mist in an evening or night is spread over a meadow, wherein there is a river, it will be drawn up by the next morning's sun, and the day will be bright afterwards.

Where there are high hills, and the mist which hangs over the lower lands draw towards the hills in a morning, and rolls up their sides till it covers the top, there will be no rain.

In some places, if the mist bangs upon the hills, and drags along the woods, instead of overspreading the level grounds, in a morning, it will turn to rain; therefore to judge rightly of the appearances of a fog, it is in some degree neccisary to be acquainted with the nature of the country.

\section{SIGNS FROM THE CLOUDS.}

It is a very considerable symptom of fuir weather, when the clonds decay, and dissolve 
themselres.into air; but it is otherwise when they are collected out of it.

In nubem cogiter aer.

Virigrt.

Against heary rain, every clond rises bigger than the former, and all the clouds are in a growing state.

This is most remarkable on the apprnach of a thunder storm, affer the vapours have been copionsly elevated, suspended in the sky by the heat, and are highly charged with electrical fire; small tragments of flying clouds increase and assemble together, till in a short space of time they cover the sky.

When the clouds are formed like ficeces, deep, and dense toward the middie, and rery white at the edges, with the sky very bright and blue about them, they are of a frusty coldness, and wiil soon fall either in hail, snow, or in hasty showers of rain.

If clouds are secn to breed high in the air, in thin white trains, like locks of wool, or the tails of horses, they shew that the vapour as it is collected, is imegularly spread and scattered by contrary winds above; the consequence of which will soon be a wind below, and probably a rain with it.

If the clouds, as they come forward, seem to diverge from a point in the horizon, a wind may be expected from that quarter or the opposite.

When a general cloudiness covers the sky above, and there are small black fragments of clonds, like smoke, flying underneath, which some call messengers, other's Noah's Ark, because they sail over the other clouds, like the ark upon the waters, rain is not far off, and it will probably be lasting. 
There is no surer sign of rain than two different currents of clotds, cspecially if the undermost ties fast before the wind; and if two such carrents appear in the hot weather of the summer, they shew that a thunder storm is gatherin of thunder, is so gुenerally understood, that it is neclless to insist upon it ininutely.

\section{STGNS FROM TME DEH.}

If the dew lies plentifully upon the grass after a fair day, another fair day may be expected to succeed it; but if after such a day there is no dew upon the ground, and no wind stirring, it is a sign that the vapours go upwards, and that there will be an accumulation above, which must terminate in rain.

\section{SIGNS FROA THE FACE OF THE SKI.}

If those vapours which the heat of the day raises from the earth, are precipitated by the cold air of the night, then the sky is clear in the morning; but if this does not happen, and they remain still in the air, the light of the morning will be coloured as it was in the evening, and rain will be the conscanerice.

There is commonily either a strong dew, or a mist over the ground, between a red evening and a grey morning; but if a red morning succceds, there is no dew.

It is a bad symptom when a lowering redness is spread too far upwards from the horizo!?, either in the morning or in the erening; it is succeeded either by rain or wind, and frequently both. 
When such a fiery redness, together with a raggeddness of the clouds, extends towards the zenith in an evening, the wind will be high from the west or south-west, attended with rain sometimes with a flood: before the late oreadful hurricane of 17S0, at Barbadoes and the other West-India Islands, a redness like fire was observed all over the sky. When the sky, in a rainy scason is tinged with sea-green colour, near the horizon, when it ought to be blue, the rain will continue and increase it it is of a deep dead blue, it is abundautly loaded with vapours, and the weather will be showery.

\section{SIGNS FROM TIE SUN, HOON, AND STARS.}

When there is a haziness aloft in the air, so that the sun's light fades by degrees, and his orb looks whitish and ill-defined, it is one of the most certain signs of rain.

If the monn and stars grow dim in the night, with the like haziness in the air, and a ring or halo appears round the monn, rain will be the consequence.

If the rays of the sun, breaking through the clouds, are visible in the air, and appear like those horns of irradiation which painters usually place upon the head of Moses, the air is sensibly filled with vapours, which reflect the rays to the sight, and these vapours will soon produce rain.

If the sun appears white at his setting, or shorn of his rays, or goes down into a bank of clouds, which lie in the horizon; all these are signs of approaching or continuing bad weather.

If the moon looks pale and dim, we are to ex- 
pect rain; if red, it is a sign of wind; and if white, and of her natural colour, and the sky clear, it will be fair weather, according to a poetical adage,

Pallida luna pluit, rubicunda flat, alba serenat.

If the moon is rainy throughout her course, it will clear up at the ensuing change, and the rain will probably commence again in a few days after, and continue; if, on the contrary, the moon has been fair throughout, and it rains at the change, the fair weather will probably be restored about the fourth or fifth day of the moon, and continue as before.

Sin ortu quarto (namque is certissimus autor) Pura, neque obtusis per calum cornibus ibit, Totus et ille dies, et qui nascentur ab illo Exactum ad mensem, pluvia ventisque carebunt.

Virg. Georg. 132.

But four nights old, (for that's the surest sign,) With sharpen'd horns, if glorious then she shine: Next day, not only that, but all the moon, 'Till her revolving race be wholly run, Are void of tempests.

DRYDEN.

N. B. A gentleman who cuts hay for his own consumption, will seldom fail to find his account in marking this observation; but a farmer who has mach business to do, cannot contract his work into so surall a compass, as to save himself by the benefit of this observation, because some of his work must be done to make way for the rest. 


\section{SIGNS FROM TIIE WINDS.}

When the wind vers about, uncertainly, to several points of the compass, rain is pretty sure to follow.

Some have remarked, that if the wind, as it veers about, follows the course of the sun, from the east towards the west, it brings fail weather; if the contrary, foul; but there is no prognostir: of rain more infallible, than a whistling or howling noise of the wind.

\section{FROM NOCTURNAT METEORS.}

When an Aurora borealis appears, after some warm days, it is generally succeeded by a coldness of the air : as if the matter of heat was carried upwards from the earth to the sky.

\section{SIGNS OF THE CHANGE OF WEATHER FROMT THE AMLMAL CREATION.}

So long as the swallows fly aloft after their prey, we think ourselves sure of a serene sky; but when they skim along near the ground, or the surface of the water, we judge the rain is not far off, and the observation will seldom fail: in the year 1775 , a draught of three months continuance broke up at the summer solstice: the day before the rain came upon us, the swallows flew very near the ground, which they had never done in the fine weathes:

In the mountainous country of Derbyshire, which goes by the name of the Peak, the inhabitants observe, that if the sheep wind up the hills in the morning to their pasture, and feed 
near the tops, the weather, though cloudy and drizzling, which is very frequently the case in those parts, will clear away by degrees, and terminate in a fine day; but if they feed in the bottoms, the rains will continue and increase.

Dogs grow sleepy and stupid before rain, and shew that their stomachs are out of order, by refusing their food, and eating grass, that sort which is hence called dog's grass: this they cast up again soon afterwards, and with it the foulness that offended their stomachs. Water-fowl dive and wash themselves more than ordinary; and even the fish in rivers are affected, because all anglers agree, that they never bite fieely when rain is depending. Vide part 1 st, rule 16 th. Flies, on the contrary, are particularly troublesome, and seern to be more hungry than usual; and toads are seen in the evening, crawling across the road or beaten path, where they seldom appear but when they are restless with an approaching change.

Before any considerable quantity of rain is to lall, most living creatures are affected in such sort as to render them some way sensible of its approach, and of the access of something new to the surface of the earth, and of the atmosphere. Moles work harder than ordinary, they throw up more earth, and sometimes come forth: the worms do so too; ants are observed to stir about, and bustle more than usually for: some time, and then retire to their burrows before the rain falls. All sorts of insects and flies are more stirring and busy than ordinary. Bees are ever on this occasion in fullest employ; but betake themselves all to their hives, if not too far for them to reach before the storm arises. The common flesh-fies are more bold 
and greedy: snails, flogs, and toads, appear disturbed and uneasy. Fishes are sullen, and made qualmish by the water, now more turbid than before. Birds of all sorts are in action: crows are most earnest after their prer, as are also swallows and other small birds, and therefore they fall lower, and fly nearer to the earth in search of insects and such other things as they feed upon. When the mountains of the north begin to be capped with fogs, the moorcocks and other birds quit them, fly off in flocks, and betake themselves to the lower lands for the time. Swine discover great uneasiness; as do likewise sheep, cows, and oxen, appearing more solicitous and eager in pasture than usual. Even mankind themselves are not exempt from some sense of a change in their bodies.

\section{PROGNOSTICS CONTINUED.}

10. "A dark, thick, sky, lasting for some time without either sun or rain, always become first fair, than foul, i. e." Changes to a fair, clear sky, before it turns to rain. This the Rev. Mr. Clarke, who kept a register of the weather for thirty years, since put into Mr. Derham's hands, by his grandson, the learned J):. Samuel Clarke: this, he says, he scarce ever knew to fail; at least when the wind was in any of the easterly points: but Mr. Derham has observed the rule to hold good, be the wind where it will. And the cause is obvious: The atmosphere is replete with rapours, which, though sufficient to reflect and intercept the sun's rays from us, yet want density to descend; and while the vapours continue in the same state, the weather will do so 0 . 
Accordingly, such weather is generally attended with moderate warmth, and with little or no wind to disturb the vapours, and an heavy atmosphere to sustain them, the barometer being commonly high. But when the cold ap proarhes, and by condensing, drives the vapours into clouds or drops, then way is made for the sun-beams; till the same vapours being, by further condensation, formed into rain, fall down into drops.

$2^{\circ}$. "A change in the warm th of the weather, is generally followed by a change in the wind." Thus, the northerly and southerly winds, commonly esteemed the causes of cold and warn weather, are really the effects of the cold or warmth of the atmosphere: of which $\mathrm{Mr}$. Derham assures us he has had so many confirmations, that he makes no doubt of it. Thus it is common to see a warm southerly wind suddenly changed to the north, by a fall of snow or hail; or to see the wind, in a cold frosty morning, north, when the sun has well warmed the earth and air, wheel towards the south; and again turn northerly or easterly in a cold evening.

30." Most vegetables expand their flowers and down in sun-shiny weather, and towaids the evening; and against rain close them again ;" especially at the beginning of their flowering, when their seeds are tender and sensible. This is visible enough in the down of dandelion, and other downs: and eminently in the flowers of pimpernel; the opening and shutting of which, Gerard observes, are the countryman's weatherwiser, whereby he tells the weather of the following day. The rule is, if the flowers are 
close shut up, it betokens rain and foul weather: if they are spread abroad, fair weather. Ger. Herb. Lib. 2.

Est et alia (arbor in Tylis) similis, foliosior tamen, roseique floris; quem noctu comprimens apevire incipit solis exhortu, meridie expandit. Incole dormire eum dicunt. Plin. Nat. Hist. Lib. 1\%. c.2.

The stalk of trefoil, my Lord Bacon observes, swells against rain, and grows more upright: and the like may be observed, though not so sensibly, in the stalks of most other plants. He adds, that in the stubble-fields there is found a small red flower, called by the country people roincopipe; which, opening in the morning, is a sure indication of a fine day.

"ithat vegetables should be affected by the same causes that affect the weather, is very conceivable; if we consider them as so many hygrometers and thermometers, consisting of an infinite number of tracheæ or air vessels; by which they have an immediate communication with the air, and partake of its moisture and heat, ic. These tracheæ are very visible in the leaf of the scabiose, vine, \&c.

Hence it is, that all wood, even the hardest and most solid, swells in moist weather; the vapours easily insinuating themselves into the pores thereof, especially of that which is lightest and driest. And hence we derive a very extraodinary use of wood, viz, for breaking rocks and inill-stones. The method at the guarries is this: Having cut a rock into a cylinder, they divide that into several lesser cylinders, by making holes at the proper distances round the great one: these holes they fill with so many pirces of sallow wood, dried in an oren; 
which, in moist weather, becoming impregnated with the humid corpuscles of the air, swell; and, like wedges, break or cleave the rocks into several stones.

The speedy drying of the surface of the earth, is a sign of a northerly wind and fair weather; and its becoming moist, of southerly wind and rain. Hence the farmer may be instructed, never to trust a sun-shiny day, while the surface of the earth continues wet; and to rely on a change to dry weather, as soon as he observes the moisture dried up, even though the appearance of the clouds should not be favorable; for the air sucks up all the moisture on the surface of the earth, even though the sky be overeast, and that is a sure sign of fair weather; but if the earth continues moist, and water stands in shallow places, no trust should be put in the clearest sky, for in this case it is deceitful.

\section{ADDENDA.}

MORE SIGNS FROM ANIMALS.

AAINST rain fleas bite more than comA mon, spiders crawl abroad, bees stir not far from their hives. On the contrary, spiders' webs in the air, or on the grass or trees, foretel very fair and hot weather; so do bees when they fy far from their hives, and come late home; and likewise a more than usual appearance of glow-worms by night. If gnats play up and down in the open air near sun-set, they presage heat, if in the shade, warm and mild showers; but if they join in stinging those that 
pass by them, cold weather and much rain may be expected. Larks rising very high, and continuing to sing for a long time, and kites flying alofi, are signs of fair and dry weather. In men, frequently aches, wounds, and corns, are more troublesnme, either towards rain or towards frost.

Virgil's beantiful description of this sense in animals, is thus rendered by Mr. Dryden:

Wet weather seldom hurts the most unwise; So plain the signs, such prophets are the skies:

The wary crane foresees it first, and sails

$\Lambda$ bove the storm, and leaves the hollow vales:

The cow looks up, and fiom atar can find

The change of lieav'n, and snuff:' it in the wind.

The swallow skims the river's watry face,

'The frogs renew the croaks of their loquacious race.

The careful ant her secret cell forsakes, Aud draws her eggs along the narrow tracks. Hinge flocks of risiug rooks forsake their food, Aul, cryine, seek the shelter of the wood.

Besides, the several sorts of wat'ry fowls, 'That swim the seas or haunt the standing pools, Then lave their lacks with sprinkling dews in vain, And stem the stream to meet the promis'd rain. 'Then, after showers, 'tis easy to déscry, lReturning suns, and a serener sky.

Their litter is not toss'd hy sows unclean,

And owls, that mark the setting-sun, declare A star-light ev'ring, and a morning fuir. Then thrice the ravens rend the liquid air, And croaking notes pruclaim the settled fair : Then round their airy palaces they fly

'To greet the sun, and seiz'd winh secret joy

When storms are overblown, with food reprair To their forsaken nests and callow care.

The crow has been particularly remarked by the ancients to presage rain, when she caws, 
and walks ilone on the sea-shore, or on the banks of rivers and pools. Thus Virgil, in the first Georgic.

Tum cornix raucà pluviam vocat improba voce,

Et sola in siccò secum spatiatur arent̀.

The crow with clamorous cries the shower demands, And single stalks along the desert sands.

UTY DEN.

- Pliny makes the same observation, in the 35th chap. of his 18th book: Et cum teriestes volucres contra aquas clangores fundentes sese sed maximè cornix: "It is as sign of rain, when land-fowl, and especia!ly crows, are clamorous near waters, and wash themselves.'

Horace also expresses himself to the same purpose, in the 17 th Ode of the third book, where he says,

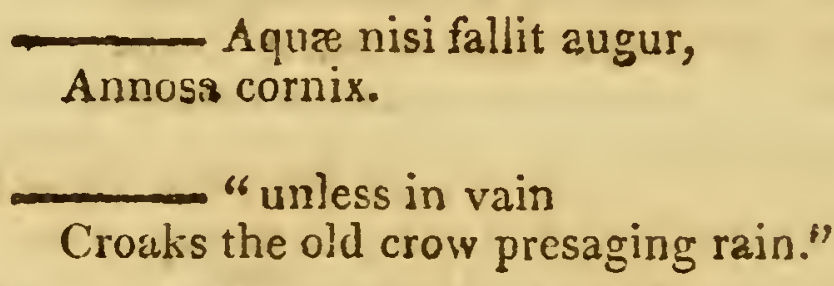

Likewise in the $2 \%$ th Ode of the same book, he calls the crow, divinam imbrium imminentium; prophetic of impending showers.

HORE PROGNOSTICS OF THE WEATHER, TAKEN FROM THE SUN, MOON, AND STARS.

1st Rule. If the sun rise red and fiery, wind and rain.

ed Rule. If clondy, and the clouds soon decrease certain fair weather.

These rules may be extended to all the hea- 
venly bodies; for as their rays pass through the atmosphere, the vapours in the air have the same effect on each.

When the farmer therefore sees the sun or moon rise or set red and fiery, or sees the clouds and horizon of that colour, he mây expect wind and rain, owing to the unequal distribution of the vapours, or to their being already collected into watery globules by some preceding cause.

But if, according to the second rule, the sun rises cloudy, and the clouds soon decrease, the vapours are more equally distributed in the atmosphere; which equal distribution is also promoted by the warmth of the rising sun. Hence we may account for an observation adopted into all languages.

The evening red, the morning grcy, Are sure signs of a fuir day.

For if the abundance of vapours denoted by the red evening sky falls down in dew, or is otherwise so equally dispersed in the air, that the morning shall appear grey, we may promise ourselves a fair day, from that equal state of the atmosphere.

If in the morning, some parts of the sky appear green between the clouds, while the sky is blue above, stormy weather is at hand.

The great Lord Bacon gives us the following rules to judge of the ensuing weather, from the first appearance of the moon; and it is said that these rules of his have never been known to fail.

If the new moon does not appear till the 
fourth day, it prognosticates a troubled air for the whole month.

If the moon, either at her first appearance, or within a few days after, has her lower horn obscured or dusky, or any ways sullied, it denotes foul weather before the full; but if she be discoloured in the middle, storms are to be expected about the full, or about the wane, if her upper horn is affected in like manner.

When the moon, on her fourth day, appears fine and spotless, her horns unblunted, and neither flat nor quite erect, but betwixt both, it promises fair weather for the greatest part of the month.

An erect moon is generally threatening and unfavourable, but particularly denotes wind; though if she appear with short and blunted horns, rain is rather expected.

Most of the foregoing rules are taken from the following beautiful passage of Virgil:

Observe the daily circle of the sun,

And the short year of each revolving moon:

By them thou shalt foresee the following day;

Nor shalt a starry night thy hopes betray.

When first the noon appears, it then she shrouds

lier silver crescent, tipp'd with sable clouds:

Concludes she bodes a tempest on the main, And brews for fields impetuous floods of rain. Or if her face with fiery flushings glow, Expect the rattling winds aloft to blow.

But four nights old (for that's the surest sign)

With sharpen'd horns, if glorious then she shine,

Next day, not only that but all the moon,

"Till ther revolving race be wholly run,

Are roid of tempests both hy sea and land.

Above the rest, the sum, who never lies,

Foretels the change of weather in the shies;

For if he rise unwilling to his race,

Clouds on his brow and spots upon his face; 
Or if thro' mists he shoots his sullen bearns, Frugal of light, in loose and stragglinerg streains; Suspect a drizzling day with southern rain.

Or it Aurora, with half open'd eyes, And a pale sickly elicek, salute the skies ; How shall the vine, her tender leaves defend Her tceming clusters when the storns descend?

But more than all the setting-sun survey, When down the steep of heav'n he drives the day: For ofi' we find him fiushing his race, with varions colours erring on his face; If fiery red his glowing globe descends, High wiuds and furious tempests he portends; [iut if his cheeks are swoln with livid blue, He bucles wet weather by his wat'ry bue; If dusky' spots are varied on his brow, And strealied with red, a trunbled colour shew, That sullen nixture shatl at once declare Winds, rain, and storms, and elcmental war.

But if with purple rays he hrings the light, And a pure heav'n, resigns to quict night; No rising winds nor falling storms are nigh.

MORE IROGNOSTICS, TAKEN FROM THE CLOUDS.

3d Rule. Clouds large, like rocks, great showers.

4th Rule. If small clouds increase, much rain. 5 th Rule. li large clouds decrease, fair weather.

6th Rule. In summer or harvest, when the wind has been south two or three days, and it grows very bot, and you see clouds rise with white tops, like towers great as if one were on the top of another, and joined together with black on the nether side, there will be thunder and rais suddenly. 
7 th Rule. If two such clouds rise, one on either hand, it is time to make haste to shelter.

Mr. Worlidge gives us the following Rules.

"In a fair day, if the sky seems dappled with white clouds, (which is usually termed a mackrel sky) it generally predicts rain."

This is confirmed by a very ingenious gentleman, who has constantly observed, that "in dry weather, so soon as clouds appear at a great height, striped like the feathers in the breast of a hawk, rain may be expecter in a day or so."

"In a clear evening, certain small black clouds appearing, are undoubted signs of rain to follow: or if black or blue clouds appear near the sun, at any time of the day, or near the moon by night, rain usually follows."

"If small waterish clouds appears on the tops of hills, rain follows."

"If clouds grow, or appear suddenly, the air otherwise free from clouds, it denotes tempests at hand, especially if they appear to the south or west."

"If many clouds, like fleeces of wool, are scattered from the east, they foretel rain within three days.

When clouds settle upon the tops of mountains, they indicate hard weather.

When the tops of mountains are clear, it is a sign of fair weather.

MORE PROGNOSTICS TAKEN FROM MIST.

8 th Rule. If mists rise in low grounds and soon vanish, fair weather.

9 th Rule. If it rises up to the hill tops, rain in a day or two. 
10th Rule. A general mist before the sun rises, near the full moon, fair weather

\section{HORE PROGNOSTICS TAKEN FROM RAN.}

IIth Rule. Sudden rains never last long: but when the air grows thick by degrees, and the sun, moon, and stars, shine dimmer and dimmer, it is likcly to rain six hours usually.

a 2 th liule. If it begins to rain from the south, with a high wind, for two or thrce hours, and the wind falls, but the rain continues, it is likcly to rain twelve hours or more; and does usually rain till a strong north wind clear's the air: these long rains seldom hold above twelve hours, or happen above once a year. "In an inland country," says Mr. Mills, "it may not rain for more than twelve hours successively; but I doubt this will not hold a general rule, either of its duration or frequency, in all places; for, near the sea, rains inappen often which last a whole day."

$13 t h$ Rule. If it begins to rain an hour or two before sun-rising, it is likely to be fair before noon, and to continue so that day; but if the rain begins an hour or two after sun-rising, it is likely to rain all that day, except the rainbuw be seen before it rains.

Mr. Worlidge's signs of rain are the following:

"The audibility of sound are certain prognostics of the temper of the air in a still evening. for it the air is replete with moisture over us, it depresses the suunds, so that they become audible to a greater distince than when the air is free from such moisture and vapours. From whence you may conclude, that in such nights, or other R 9 
times, when you hear the sound of bells, noise of water, beasts, birds, or any other sounds or noises, more plainly than at other times, the air is inclineable to rain, which commonly succeeds."

"If the earth, or any moist or fenny places, yield any extraordinary scents, or smells it presages rain."

"If dews lie long in the morning on the grass, \&c. it significs fair weather; but if they rise or vanish suddenly and early in the morning, it presages rain."

"There is a small bird of the size and nearly the shape of a marten that at certain times Hies very near the water, which is a most sure prognostic of tempestuous weather; never appealing but against such weather as hath been constantly observed by the boatmen on the Severn and the channel, between the Isle of "Wight and the main-land."

"Ducks and geese picking their wings, washing themselves much, or cackling much, denotes rain."

"If after rain comes a cold wind, there will be more rain."

The nightly virgin, whilst her wheel she plies,

Foresees the storm impending in the skies.

When sparkling lamps their sputt'ring light advance, And in their sockets oily bubbles dance.

DKYDEN'S VIRGIL.

\section{AIORE PROGNOSTICS FROM THE WIND.}

14th Rule. When the wind turns to north-east, and it continues there two days without rain, and does not turn sonth the third day, nor rain the third day, it is likely to continue north-east for 
eight or nine days ail fair, and then to come south again.

1.jth likule. If it turn again out of the south to the north-east with rain, and continues in the north-east two days without rain, and neither turns south nor rains the third day, it is likly to. continue north-east tiro or three months.

The wind will finsh these turns in three wceks.

16 th Rule. After a northerly wind, for the most of two moths or more, and then coming south, there are ustally three or four fair days at first, and then on the fourth or fifth day comes rain, or else the wind turns north again and continues dry.

If th Kinle. If it retums to the south within a day or two, without rain, and turns northward with rain, and returns to the south in one or two days, as before, two or three times togetier after this sort, then it is likely to be in the sunth or south-west two or three months together, as it was in the north before.

The winds will finish these tums in a fortuight.

1Sth Rule. Fair weather for a wcek, with a sontherly wind, is likely to prodice a great dronght, if there has been much rain ont of the south before. The wind usually turns firom the north to south with a quiet wind without rain; but returns to the north with a strong wind and rain. 'The strongest winds are when it turns from south to nowh by west.

1gth Rule. If you see a clond rise against the wind, or side wind, when that elourl comes up to you, the wind will blow the same way the cloud came. The same rule holds of a clcar place, when all the sky is equally thick, except one clear edge.

When the north wind first clears the air, 
which is usually once a week, be sure of a fair day or two.

The following are the observations of Lord Bacon:

When the wind changes conformable to the motion of the sun, that is, from east to south, from south to west, \&c. it seldom goes back, or if it does, it is only for a short time; but if it moves in a contrary direction, viz. from east to north, from north to west, it generally returns to the former point at least before it has gone quite through the circle.

When winds continue to vary for a few hours, as if it were to try in what point it should settle, and afterwards begin to blow constant, they continue for many days.

If the south wind begins for two or three days, the north wind will blow suddenly after it; but if the north wind blows for the same number of days, the south will not rise till after the east has blown some time.

Whatever wind begins to blow in the morning, usually continues longer than that which rises in the evening.

Mr. Worlidge observes, that " if the wind be east, or north-east in the fore part of the summer, the weather is likely to continue dry: and if westward towards the end of the summer, then will it also continue dry: if in great rains the winds rise or fall, it signifies the rain will forthwith cease.

"If the colours of the rainbow tend more to red than any other colour, wind follows; if green or blue are predominant, rain." 


\section{THE SIGNS OF A TEMPEST ARE TIIESE:}

For ere the rising winds begin to roar, The rorking sea advances to the shure; Soft whispers run along the leafy woods, And mountains whistle to the murm'ring floods ; And chaff with eddying wings is toss'd around, And dancing leaves are lifted from the ground, And tloating feathers on the water play.

\section{PROGNOSTICS CONTINUED.}

20th Rule. If the last eighteen days of February, and the first ten days of March,* are for the most part rainy, then the spring and summer quarters will be so too: and I never knew a great drought but it entered in at that season.

2Is Rule. If the latter end of October and beginning of November are for the most part warm and rainy, then January and February are likely to be firosty and cold, except after a very dry summer.

$22 \mathrm{~d}$ Rule. If there is frost and snow in October and Noven ber, then January and February are likely to be open and mild.

Mr. Claridge gives us the following observations made by our forefathers:

Janiveer freeze the pot by the fire.

If the grass grows in Janiveer,

It grows the worse for't all the year.

'The Welshman had rather see his dam on the bies; Than see a fair Februeer.

March wind and May sun

Makes clothes white and maids dun.

* Old Style. 
When April blows his horn, 'Tis good both for hay and corn.

An April flood

Carries away the frog and her brood.

A cold May and windy

Makes a fuil bam and a fudy.

A May food never did good.

A swarm of bees in Nay

Is worth a load of hay.

But a swarm in in July

Is not worth at fiy.

The following Rules are laid down by Lord Bacon:

If the wainscot or walls that used to sweat be drier than nsual, in the begiming of winter, or the eves of houses drop more slowly than ordinary, it portends a hard and frosty winter; for it shews an inclination in the air to dry weather, which, in winter, is alwars joined with liost.

Generally, a moist and culd summer portends a hard winter.

A hot and dry summer and autumn, especially if the heat and drought extend far into September, portend an open beginning of winter, and cold to succeed towards the latter part, and beginning of spring.

A warm and open winter portends a hot and dry summer, for the vapours disperse into the winter showers; whereas cold and frost keep them in, and convey them to the late spring and following summer.

Birds that change countries at certain seasons, if they come carly. shew the temper of the weather, according to the country whence they came; as, in winter woodcocks, snipes, fieldfares, \& c c. if they come early, shew a cold winter; and the 
cuckoos, if they come early, shew a hot summer to follow.

A serene autumn denotes a windy winter; a windy winter a rainy spring; a rainy spring, a serene summer; a screne summer, a windy alutumn; so that the air, on a balance, is seldom debtor to itself; nor do the seasons succeed each other in the same tenor for two years together.

Mr. Worlidge remarks, that it at the beginning of the winter the south-wind blow, and then the north, it is likely to be a cold winter; but if the north-wind first blow, and then the south it will be a warm and mild winter.

When there are but few nuts, cold and wet harvest generally follow; but when there is a great shew of them, hot, heavy, and dry harvests succeed.

If the oak bears much mast, it foreshews a long and hard winter. The same has becn observed of hips and haws.

If broom is full of flowers, it usually signitiec plenty.

Mark well the flow'ring almonds in the, whod; If od'rous blooms the bearing branches loid, The glebe will answer to the Sylvan reign,

Great heats will follow, and large crops of grain. But if a wood of leaves o'ershade the tree, Such and so barren will the harvest be.

In vain the hind shall vex the threshing floor, For empty chaff and straw will be thy store.

$$
\text { DRYIIEN'S VIRGIL. }
$$

In the preface to this new edition, Fhave taken notice, that I have not revised any impression of this treatise since the fifth, and at the conclusion of that have observed, "that through the uncertainty of life I might not do so "ugain." However through the blessings of the AL- 
MIGHTY, I am enabled to present the reader with a new copy, and again take my leave of him, wishing him health, prosperity, and good sport.-I shall now, (following the example of my pious predecessor W A LTON, address 'HAT POWER, who penetrates and sustains all nature, who brings round the grateful vicissitude of the seasons, who has given us the inhabitants of the watery element not only for our nourishment, but recreation, and Whom we are sure to please, by receiving his blessings thankfully, and enjoying them with propriety.

\section{YMN.}

Father of all!-all good!-all wise!

Who bid'st the tempest rage or ceise;

Whose glory fills earth, seas, and slies,

Thon only source of joy and peace;

Thy wise decrees are right and just,

Let no one, impious! iax thy will :

But on thy glorionis mercies trust,

And see a good, thro' ev'ryill:

Arm-arm, with fortitude my breast,

The various ills of life to bear;

And teach thy servant when at rest,

For sturms and troubles to prepare:

But thro' whate'er distressfil scone,

'Thy righteous hand may learl me still;

Rosigin'd to what may evil seem,

Content my breast shall calmly fill:

And as theseasons onward roll, And years revolvmg quickly fiy;

Sweet gratitude shall wam my soul, For all the blessings I enjoy:

Still-still I'll praise that heav'n!y source,

For what it ploases to bestow;

That petrifies the streamlet's cuurse,

Gir bids its silver current How: 
That regulates creation's laws, bids all in harmony unite; And is,--The unizicrsal cause,

Uf ev'ry thing that's good and right;

\section{$\therefore=$ \\ TERMS USED BY ANGLERS EYYLATYEDD.}

Bawli, a knot in a hair or link.

Berl, hairs bed well when they twist kindly.

Bedding, the body of an artificial $\mathrm{Aly}$.

Break, a knot in the joint of a rod.

Chine a srémon, cut him up.

Cock, a float cockswhen it swims perpendicular in the water.

Drag, an instrument to disentangle tire line.

Fin a rhub, cut him up.

Frush a chub, dress him.

Gildard, the link of a line.

Gobbet a trout, cut him up.

Grabble, fishing on the grabble is when the line is sunk with a running plummet fast to the bottom, so that the hook-link plays in the water. Fang ufish, hook him.

Kink, a line kinks in trowling, when it is twisted between the top of the rod and the ring. Lease of fish, three.

Pouch, a pike pouches when heswallows the bait. Prime, fishes are said to prine when they leap out of the water.

Shoul, any great number of fish together.

Solay a breain, cut him up.

Splate a pike, cut him up.

Thrash, any thing which swims down the water. Trouncheon an eel, cut him up.

Tusk a barbel, cut him up.

$V$ eer your line, let it off the reel after striking. 


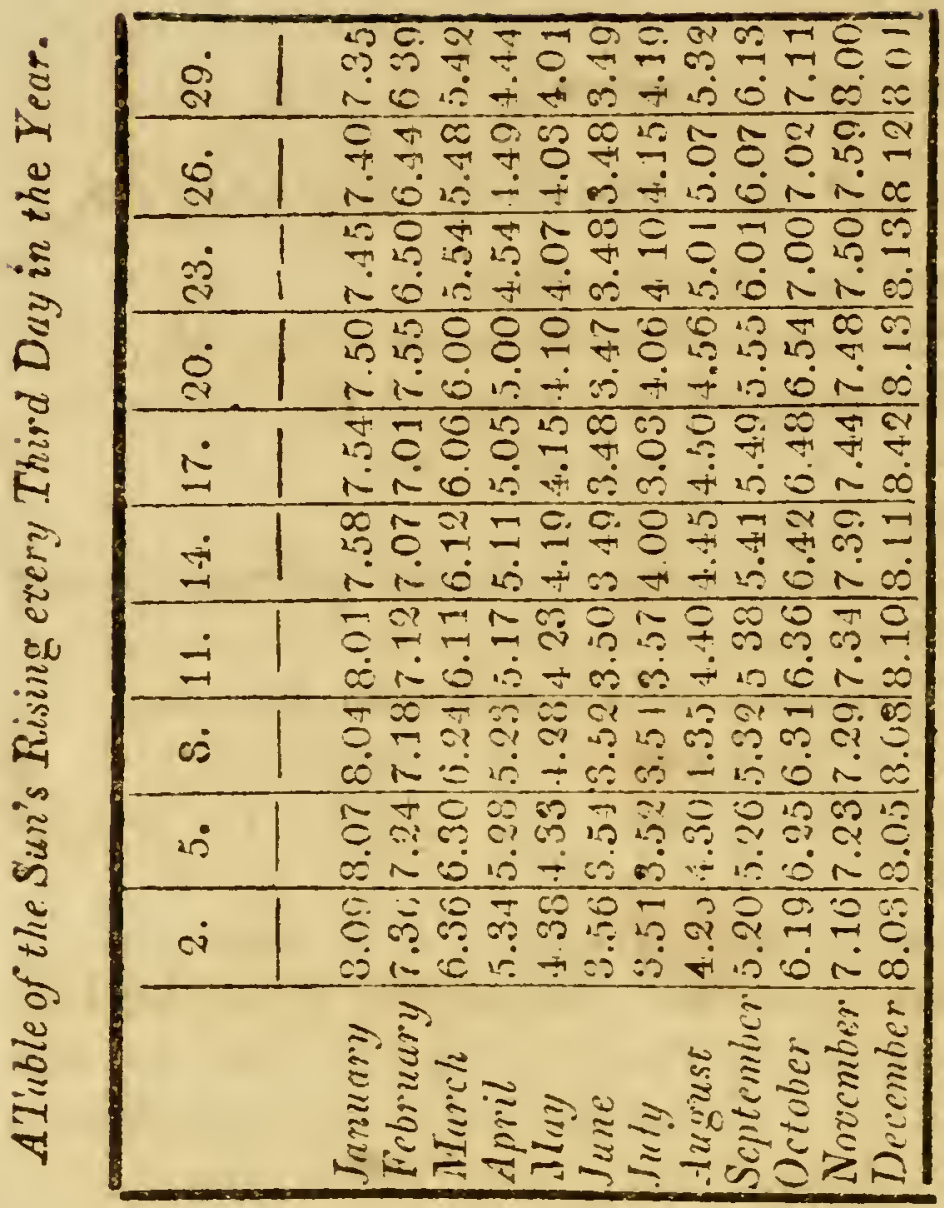

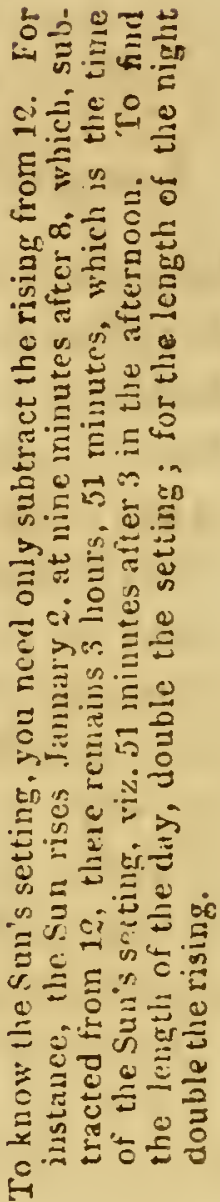

\section{MOON'S RISING AND SETTING.}

At $\$$ days old it sets at and shines tiil/ 16 at a quarter after 7 Even. about 10 at night.

5 , abrout 11

6. alout 12

7 at or uear: in the morning.

15, at full, it rises aboul 6 Even.

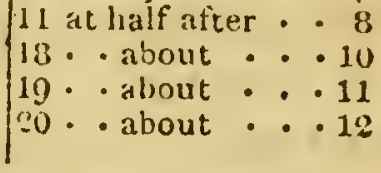

18. about . . 10

19. about . . 11

Tout $\cdot 0$

Note. This Table is sufficiently accurate for the purpose it is wanted for, that of ascertaining Moun-light eveuings. 


\section{ADDENDA.}

TINOW-fishing comes in about the middile of March, and continues till the latter end of Auguist; it is a most excellent bait, very destructive, of strong exercise, being always in motion, and affords the angler variety of sport. To be angled with at any time of the day, from sun-rise till sun-set, and takes the best and largest fish.

Cod-bait-fisling comes in about a fortnight in May, and continues till about the middle of June: it is a very killing-bait, and will take almost every sort of fish, in deep standing-waters as well as in streams, mornings and evenings, till the middle of June.

Maggot, or Gentle-fishing comes in about the beginning of May, and continues till the latter: end of February, in the next year; it is the best. and most killing ground-bait that ever was made use of; it will take every sort of fish that swims in fresh water, except salmon or pike.

Grass-hopper-fishing comes in about the latter end of June, and continues till the latter end of August. It is a curious fine bait, very natural to fish, but very terder; to be drawn ujon a leaded hook, No. 2, after the same manner as the codbait, and will take almost all sorts of fish, as pike, trout, greyling, perch, chub, ròach, dace, \&c. \&c.

Cabbage-worm-fishing comes in about the iniddle of June, and continues in their successive flights, till the latter end of October. There are three 
sorts of which the fish are remarkably fond of, and are equal in goodness to the cod-bait and grasshopper, and will take the same sorts of fish.

Worm, or Bottom-fisting, comes in about the middle of February, if the weather is mild, and continues good all the year; you may fish with a worm all, or any time of the day, if the water is discoloured by rain; but if low, clear, and fine, only mornings and evenings; it is the most general bait we have, and will take every kind of fish; the proper worms for angling are fully described in this treatise.

As in successive course the seasons roll,

So circling pleasures recreate the soul :

When genial spring a living warmth bestows, And o'er the year her verdant mantle throw's, No swelling inundation hides the grounds, But chrystal currents glide within their boinds; The finny brood their wonted haunts forsake, Float in the sun, and skim along the lake;

With frequent leap they range the shallow streams, Their silver coats reflect the dazzling beams.

Now let the fisherman his toils prepare, And arm himself with ev'ry wat'ry suare; His hooks, his lines peruse, with careful cye, Increase his tackle, and his rod re-tie.

GAY.

Happy England! (says an elegant writer) where the sea furnishes an abundant and luxurious repast, and the fresh waters areinnocent and harmless pastime; where the angler in cheerful solitude strolls by the edge of the stream, and fears neither the coiled snake, nor the lurking crocodile; where he can retire at night, with his few trouts, (to borrow the charming description of old Walton) to some friendly cottage, where the landlady is good, and the daughter innocent and beautiful; where the room is cleanly, the sheets smelling of lavender, and twenty ballads stuck 
about the wall! There he can enjoy the company of a talkative brother angler, have his trouts dressed for supper, tell tales, sing old tunes, or make a catch!' There he can talk of the wonders of nature, with pious admiration, or find some harmless sport to content him, and pass away a little time, without offence to God, or injury to man!!

\section{CHAP. IX. \\ Rules to Judge of the Barometer.}

DY the help of the Barometer, we seem to re1 gain that foreknowledge of the weather which still resides in brutes, and which we forfeited, by not continuing in the open air as they generally do, and by our intemperances, lessening our sensibility of exterual objects.

The changes that take place in the atmosphere, are principally marked by the rising and falling of the Barometer, which apparently is caused by heat and cold, the hands with which Nature performs her meteorological operations; by the former the atmosphere is rarefied and consequently becomes light; by the latter it is condensed, and consequently becomes heavy.

The Barometer falls suddenly while the air is expanded before a gale of wind, and rises again gradually as the condensed air returns, and the gale in like manner by degrees subsides.

An extraordinary fall of the mercury will sometimes take place in Summer, previous to heavy showers of rain, particularly if attended with thunder and lightning; but in Spring, Autumn, and Winter, the sudden extraordinary 
descent of the Barometer indicates principally violent wind.

'The Thermometer also which measures the degree of heat in the air near the earth, will contribute towards denoting when changes are likely to take place in the lower regions of the atmosphere: The Hygrometer distinguishes the quantity of moisture in the atmosphere and the Electrometer will point out the quantity of Electricity which prevails in it.

The words generally engraven on the plates of the Barometer, serve rather to mislead than inform; for the changes of the weather depend rather on the rising or the falling of the mercury, than of its standing at any particular height.

When the mercury, is as high as fair, or at 30 degrees, and the surface of it is concave, beginning to descend, it very often rains; and on the contrairy when even the mercury is at 29 degrees, opposite to rain, when the surface of it is convex, beginning to rise, fair weather may be expected: these circumstauces not being known, or not being duly attended to, is the principal cause, that farmers and others have not a proper confidence in this instrument.

It must be observed that coters paribus, the mercury is higher in cold, than in warm weather, and commonly early in the morning, or late in the evening, than at noon, which seems occasioned by the obvious causes of the atmosphere being condensed by the cold of the night, and rarefied by the heat of the day.

The folloving observations deserve attention

1. The least alterations in the mercury are to be observed (especially in a showery time).

Q. Therising of the mercury, presages in general, fair weather, and its falling foul. 
3. In very hot weather the falling indicates thunder.

4. In winter the rising presages frost; and in frosty weather, if the mercury falls three or four divisions, a thaw; but in a continued frost, if it rises, it will certainly snow.

5. When foul weather happens sorn after the falling of the mercury, expect but little ot it; and on the contrary expect but little fair weather, when it proves fair, shortly after the mercury has risen.

6 . In foul weather, when the mercury rises much and high, and continues so for two or three day's, betore the foul weather is quite over, then expect a continuance of fair weather to follow.

7. In fair weather, when the mercury falls much and low, and continues so for two or three days, before the rain comes-then expect a great deal of wet, and probably high winds.

8. The unsettled motion of the mercury, denotes changeable weather.

0. If the mercury stands at much rain, and then rises up to changeable, it presages fair weather, although not to continue so long as it would have done if the mercury were higher: So, on the contrary, if the mercury stood at fair, and falls to changeable, it presages foul weather; but fouler if it sinks down lower.

But to these remarks it may be added, that when the Barometer suddenly falls two or three tenths, without any material alteration in the Thermometer, and the Hygrometer is not much turned towards moist, a violent gale of wind may be expected.

When the Hygrometer inclines far towards moist, with only a trifling descent in the Bare- 
meter, it denotes a passing shower and little wind; and when the Barometer falls considerably, and the Hygrometer turns much towards moist, the 'Thermometer remaining stationary, and rather inclining to rise than fall, both violent wind and rain are likely to follow in the course of a few hours.

\section{ADDENDA.}

THE Barometer is highest during a long frost, and generally rises with a North-East-Wind: it is lowest during a thaw following a long frost, and is often bronght down by a South-WestWind.

When the Barometer is near the high extreme for the season of the year, there is very little probability of immediate rain.

When the Barometer is low for the season, there is seldom a great weight of rain, though a fair day in such a case is rare: the general tenor of the weather at such times is, short, heavy and sudden showers, with squalls of wind from the S. W. or N.W.

In summer after a long continuance of fair weather, with the Barometer high, it generally falls gradually, and for one, two, or more days before there is much appearance of rain; if the fall be sudden and great for the season, it will be probably followed by Thunder.

When the appearances of the sky are very promising for fair, and the Barometer at the same time low; it may be depended upon the appearance will not continue so long: the face of the sky changes very suddenly on such occazions.

Very dark and dense clouds pass without rain when the Barometer is high: whereas when the 
Barometer is low, it sometimes rains, without almost any appearance of clouds.

All appearances being the same, the higher the Barometer is, the greater the probability of fair weather.

Thunder is almost always preceded by hot weather, and followed by cold and showery weather.

A sudden and extreme change of temperature of the atmosphere, either from heat to cold, or cold to heat, is generally followed by rain within 24 hours.

In winter during a frost if it begins to snow, the temperature of the air generally rises to 92 degress of the Thermometer, and continues there whilst the snow falls; after which if the weather clears up, expect severe cold.

The Aurora Borealis, is a prognostic of fair weather.

Dr. Kirvan has deduced from a variety of meteorological observations (to which he has had access) made in England between the year 3677 and 1788 the following probabilities or hints towards forming prognostics of the weather, viz.

"That when there has been no storm before or after the spring equinox, the ensuing summer is generally dry; at least five times in six.

"That when a storm happens from any Easterly point, either on the $19 \mathrm{~h}, 20$ th, or $21 \mathrm{st}$, of March the succeeding summer is generally dry, four times in five.

"That when a storm arises, on the 25th, 20 th, or $27 \mathrm{th}$, of March, and not before in any point; the succeeding summer is generally dry, four times in five.

"If there be a storm at S. W. or W.S W. on the i9th, 20th, or $22 \mathrm{~d}$ of March the succeeding summer is generally wet; five times in six." 
In September and October, the Winter-constitution of the air begins to shew itself. The great falls of the Barometer, from October to April, are from 29,5 to 28,5 , sometimes lower.

From April to October it seldom falls lower than 29,5 ; it therefore follows, that a fall of one inch during the Summer, is as sure an indication of rain, as a fall of between two or three tenths is in the Winter.

I shall now conclude, with a few lines which thave by me, in manuscript, written by a very ingenious angler.

The months o'er which the nearer Sun displays

Ifis warmer influence, and directer rays,

Are most propitious to the angler's toil,

And crown his labours with the largest spoil.

When birds begin in brisker notes to sing

And hail with cheerful voice returning spring;

When western winds in cooling breezes fly,

Aind brush with downy wings the hrighten'd sky;

When tender buds their virent issue yield, A and with their tender offspring grace the field; Then let the angler, with delight and care, His guileful arms and implements prepare, Break Winter's truce, and wage the wat'ry war. $\}$

But when Autumnal blasts have stripp'd the wood, And o'er the ground its yellow honors strew'd; When stormy Boreas re-assumes his reign And with malignant vapors dulls the plain; Let him awhile his favorite sport forbear; Till, by the course of the revolving year, The fairer order of the months returns, And Nature with fresh bloom her face adorns:

Then soon as morn has chas'd the shades of night, And streal'd the purple east with rosy light; Soon as the lark extends her early wings, And in the fragrant air her matin sins; The angler cheerful with the hopes of prey, Takes to the steaming brook his dewy way.

FINIS.

Plummer, Printer, Secthing-Lane, London. 
1
$+$

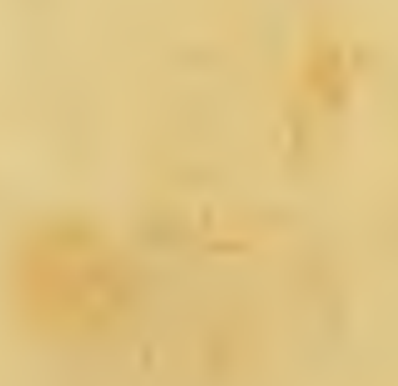



